GRøNLANDS GEOLOGISKE UNDERSØGELSE

G $E \cup \mathbf{S}$

Report file no.

22478
RAPPORT Nr. 141

The Geological Survey of Greenland

Report No. 141

Field occurrence and petrology of deformed metabasite bodies in the Rinkian mobile belt, Umanak district, West Greenland

\title{
Lasse Schiøtte
}

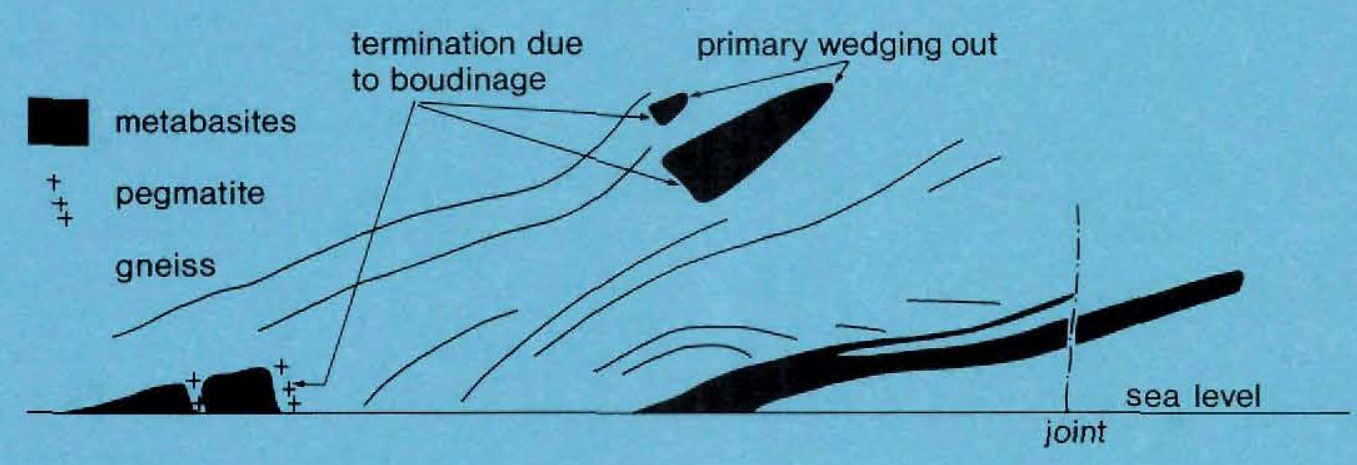




\section{Grønlands Geologiske Undersøgelse}

(The Geological Survey of Greenland)

Øster Voldgade 10, DK-1350 Copenhagen K

Denmark

\section{Reports}

No. 117 Origin of quartzo-feldspathic supracrustal rocks from the central part of the Nagssugtoqidian mobile belt of West Greenland. 1984 by A. Rehkopff.

D.kr. 33.00

No. 118 Greenschist facies metabasites from the Hellefiskefjord - G. B. Schley Fjord area, eastern Peary Land, North Greenland. 1984 by R. E. Bevins \& G. Rowbotham. D.kr. 28.00

No. 119 Precambrian gneisses and intrusive anorthosite of Smithson Bjerge, Thule district, North-West $\begin{array}{ll}\text { Greenland. } 1984 \text { by A. P. Nutman. } & \text { D.kr. } 52.00\end{array}$

$\begin{array}{lr}\text { No. } 120 \text { Report of activities, 1983. } 1984 . & \text { D. kr. } 80.00\end{array}$

No. 121 Biostratigraphic studies in western North Greenland; Operation Grant Land 1965-1966. 1984.

D.kr. 105.00

No. 122 Aeromagnetic maps of parts of southern and central West Greenland: acquisition, compilation and general analysis of data. 1984 by L. Thorning.

D.kr, 45.00 incl. map.

No. 123 The plutonic igneous and high-grade metamorphic rocks of southern Liverpool Land, central East Greenland, part of a supposed Caledonian and Precambrian complex. 1985 by R. F. Cheeney.

D.kr. 48.00

No. 124 Lithostratigraphy of the Tertiary Vaigat Formation on Disko, central West Greenland. 1985 by A. K. Pedersen.

D.kr. 32.00

$\begin{array}{ll}\text { No. } 125 \text { Report of activities, 1984. } 1985 . & \text { D. kr. } 80.00\end{array}$

No. 126 Report on the 1984 geological expedition to central and western North Greenland, 1985.

D.kr. 100.00

No. 127 Gardar dykes north of the Igaliko Syenite Complex, southern Greenland. 1985 by B. G. J. Upton \& J. G. Fitton.

D.kr. 30.00

No. 128 Developments in Greenland geology. 1986 edited by F. Kalsbeek \& W. Stuart Watt.

D.kr. 175.00

No. 129 Occurrences of anorthositic rocks in the reworked Archacan basement in the Umanak area, central West Greenland. 1986 by M. C. Andersen \& T. C. R. Pulvertaft. D.kr. 38.00

No. 130 Report of activities, 1985. 1986.

D.kr. 85.00

No. 131 Quaternary, pre-Holocene, marine events of western Greenland. 1986 by M. Kelly.

D.kr. 22.00

No. 132 North Greenland Lower Palaeozoic palaeontology and stratigraphy: short contributions. 1986 edited by J. S. Peel.

D.kr. 120.00

No. 133 Report on the 1985 geological expedition to central and western North Greenland. 1987.

D.kr. 145.00

No. 134 Geochronological studies in central East Greenland (four papers). $1987 . \quad$ D.kr. 42.00

No. 135 Report of activities, 1986, $1987 . \quad$ D.kr. 80.00.

No. 136 Early Tertiary, low-potassium tholeiites from exploration wells on the West Greenland shelf. 1987 by N. Hald \& J. G. Larsen.

D.kr. 25.00 .

No. 137 Cambrian-Jurassic fossils, trace fossils and stratigraphy from Greenland. 1988 edited by J. S. Peel.

No. 138 Glacier-hydrological conditions on the Inland Ice north-east of Jakobshavn/Ilulissat, West Greenland. 1988 by H. H. Thomsen, L. Thorning \& J. Braithwaite. D.kr. 62.00

No. 140 Report of activities, 1987. 1988.

D.kr. 120.00

No. 141 Field occurrence and petrology of deformed metabasite bodies in the Rinkian mobile belt, Umanak district, West Greenland. 1988 by L. Schiøtte. 
GRØNLANDS GEOLOGISKE UNDERS $\emptyset$ GELSE RAPPORT Nr. 141

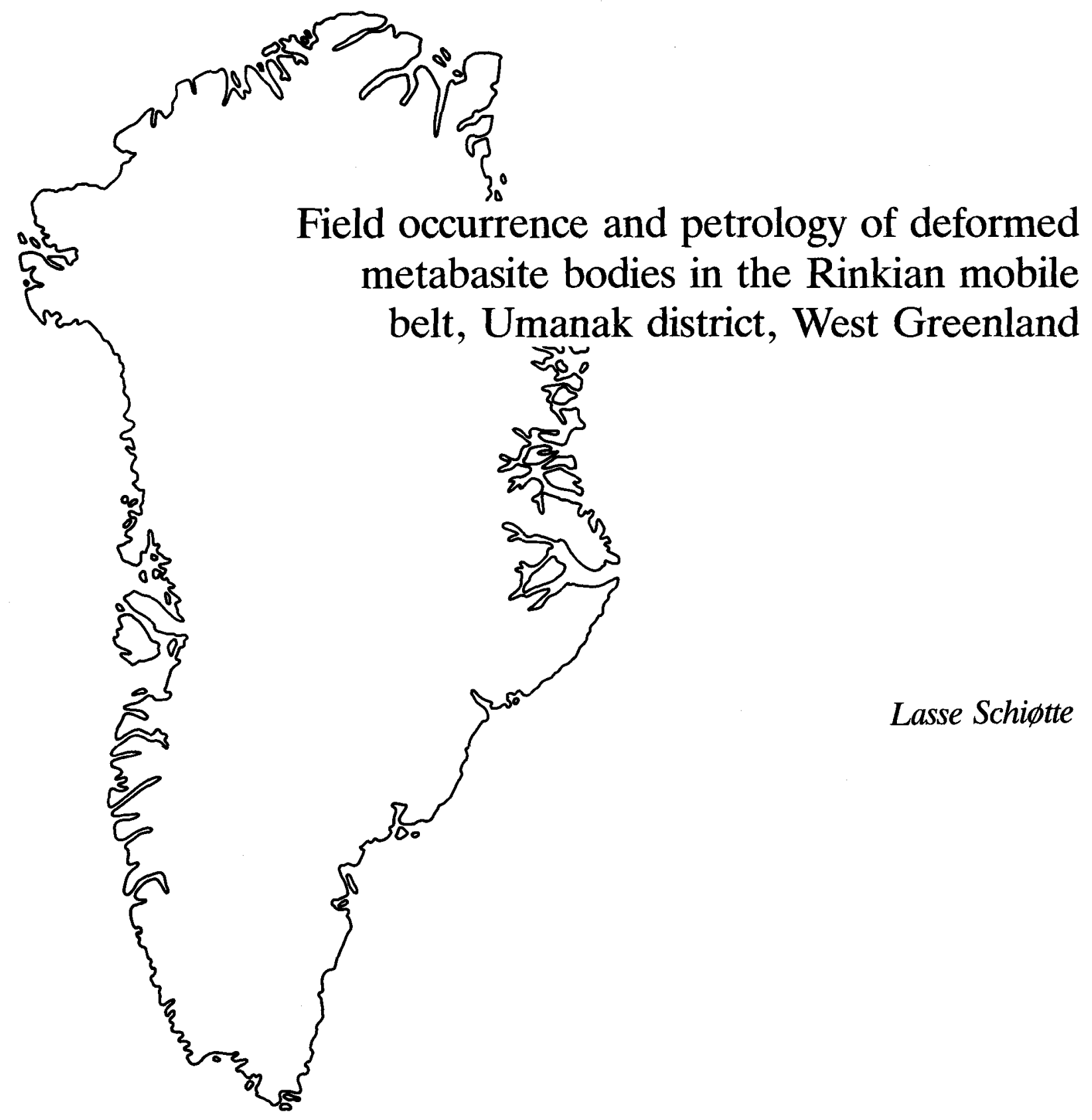




\begin{abstract}
Tabular, pod-shaped and irregular discordant metabasite bodies intruding the Archaean gneisses in the Umanak district constitute a series of tholeitic layered intrusions. The magma evolution was controlled by fractional crystallisation of olivine and $\mathrm{Cr}$-spinel in the initial stages, quickly superseded by pyroxenes. Fractional crystallisation of orthopyroxene was of major significance during most of the igneous evolution. Cumulus plagioclase came in relatively late.

The metabasite bodies are remarkably well differentiated, and differentiation in a common magma reservoir prior to emplacement is suggested. Trace element patterns and Sm-Nd isotopic characteristics are compatible with contamination in a crustal magma chamber. Crustal contamination during and after emplacement did not occur.

The igneous layering gives rise to an asymmetry which enables recognition of inversion of metabasite bodies relative to each other after their intrusion thus establishing that at least one phase of recumbent folding postdates metabasite intrusion. Probably most of the large-scale recumbent folds that characterise the tectonic pattern in the Umanak district are of post-metabasite (Rinkian) age (about 1800-1900 Ma). The metabasite bodies owe their shape partly to primary irregularities, partly to boudinage on the limbs of recumbent folds.

The Rinkian deformation was accompanied by amphibolite facies metamorphism which only weakly affected the metabasite bodies. Nevertheless they possess a dry metamorphic mineral assemblage which may either be auto-metamorphic or developed during the Rinkian deformation and metamorphism in a water deficient environment. Extensive re-equilibration of igneous minerals (particularly pyroxenes) is characteristic of this dry metamorphism. Moreover plagioclase in the olivine bearing parts of the igneous bodies is cloudy brown due to a high content of sub-microscopic spinel inclusions whilst in chemically more evolved parts of the intrusions garnet has grown at the expense of plagioclase.
\end{abstract}

Author's address:

Geologisk Museum

Øster Voldgade 5-7

DK-1350 Copenhagen $K$

Denmark 


\section{Contents}

Introduction

Geological setting.

Field relations of metabasite bodies .

Main field occurrence

The significance of folded metabasite bodies

The Ikerasak controversy

Petrology and geochemistry of metabasite bodies

Petrography. .

Early texture and mineralogy $\ldots \ldots \ldots \ldots \ldots \ldots, 12$

Ultrabasite/picrite zone ................ 12

Gabbro-noritic zone................... 14

Garnet-biotite gabbroic zone ............. 14

Plagioclase-rich sub-zone $\ldots \ldots \ldots \ldots \ldots \ldots, 14$

Central sub-zone.................. 15

Fine-grained clinopyroxene-rich sub-zone .... 15

Metamorphic effects .................. 15

Re-equilibration of igneous olivine and $\mathrm{Cr}$-spinel 16

Growth of spinel in plagioclase ........... 17

Garnet growth................... 18

Growth of pyroxene oikocrysts ........... 19
Effects on igneous pyroxenes............ 20

Amphiboles ....................... 20

Micas $\ldots \ldots \ldots \ldots \ldots \ldots \ldots \ldots \ldots \ldots .23$

Other effects of the amphibolite facies meta morphism........................ 24

Greenschist facies metamorphism .......... 24

Bulk rock chemistry.................. 24

General ......................... 24

Characteristic trends across metabasite bodies.... 29

Correlations of incompatible trace elements..... 29

Sm-Nd isotopic characteristics . . . . . . . . . . . . 29

Discussion $\ldots \ldots \ldots \ldots \ldots \ldots \ldots \ldots \ldots \ldots \ldots \ldots, 31$

Factors controlling igneous evolution ......... 31

Speculations on the magma source .......... 32

Timing of metamorphism $\ldots \ldots \ldots \ldots \ldots \ldots \ldots, 33$

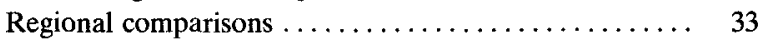

Concluding remarks $\ldots \ldots \ldots \ldots \ldots \ldots \ldots \ldots \ldots \ldots \ldots$

Acknowledgements ....................... 34

Appendix: analytical procedures ............. 34

References........................ 35 


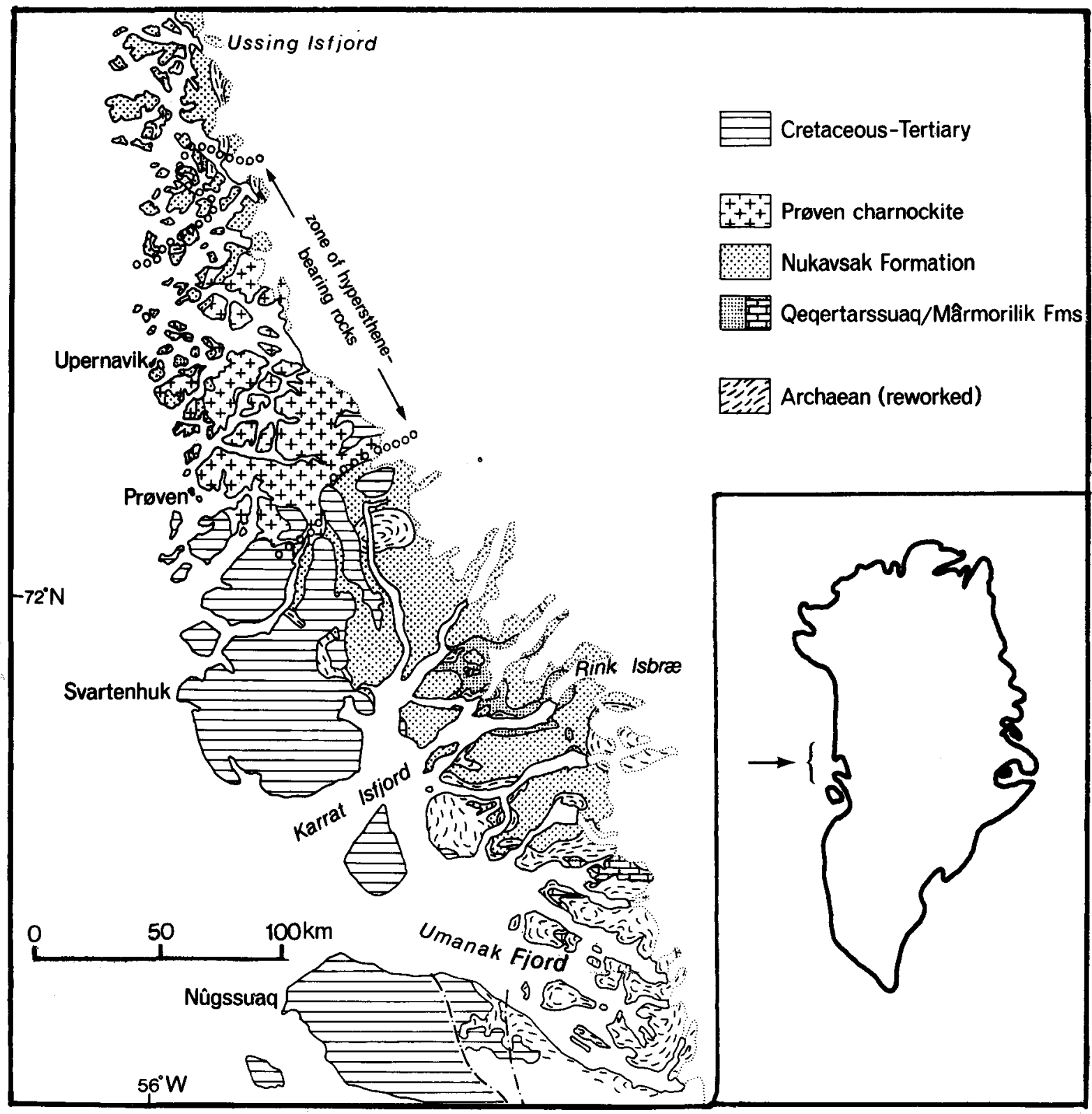

Fig. 1. Position and geological sketch map of the Rinkian mobile belt in West Greenland (modified from Escher \& Pulvertaft, 1976). 


\section{Introduction}

Tabular, pod-shaped and irregular basic intrusions varying in size from a few to several hundred metres are numerous in the Archaean basement to the Rinkian supracrustal rocks in the Umanak district, West Greenland (Pulvertaft, 1973). Their potential as chronological and structural markers was emphasised by Pulvertaft $(1973,1979)$. However, it has long been debated as to what extent irregularities in form and structure of this kind of intrusion are deformational features or whether they should rather be interpreted as the consequence of synkinematic intrusion. Schiøtte (1981) showed that at least one generation of metabasite bodies in Umanak Fjord predates the last event of recumbent folding. Grocott $(1981,1982)$ on the other hand interpreted a $200 \mathrm{~m}$ thick, partly recrystallised but apparently largely undeformed basic intrusion as synkinematically intruded towards the end of a relatively late shear zone development.

In the present paper it is argued that most metabasite bodies in the Umanak district belong to one single igneous event which predates the major part of the recumbent folding that characterises the tectonic pattern in the district. Thus Grocott's interpretation is questioned. It is shown that the metabasite bodies constitute a series of layered intrusions, and their petrology and geochemistry are outlined.

The field observations were made during regional mapping in the Umanak district in 1979 and 1980 whilst most laboratory work was carried out in 1981-1982.

\section{Geological setting}

The Umanak district belongs to the Rinkian mobile belt of West Greenland (fig. 1), a structural province which was previously regarded as part of the Nagssugtoqidian, but is now distinguished as a separate province on the basis of its structural style (Pulvertaft, 1973; Escher \& Pulvertaft, 1976; Pulvertaft, 1986). A brief description of the Rinkian mobile belt is given by Escher \& Pulvertaft (1976), whilst new information concerning a marble formation of major importance (the Mârmorilik Formation) and its relation to the Archaean basement is given by Garde (1978).

Characteristic structural features of the Rinkian mobile belt are large dome and basin structures, overturned folds and nappes, that is an Archaean basement domes up into an overlying Proterozoic supracrustal cover, causing spectacular large scale structures (Henderson, 1969). The amount of overthrusting may exceed $50 \mathrm{~km}$.

The complete sequence of Proterozoic supracrustals is several kilometres thick. In the central part of the belt it consists of a marble formation (the Mârmorilik Formation), the mainly quartzitic Qeqertarssuaq Formation and the flyschoid Nukavsak Formation, all belonging to the Karrat Group. The Mârmorilik Formation is regarded as the southerly equivalent of the Qeqertarssuaq Formation.

The basement itself is heterogeneous with a mig- matitic granodioritic-tonalitic biotite gneiss as the most prominent constituent. Its essentially Archaean age is revealed by Rb-Sr whole rock dating. Kalsbeek (1981) reports an age of $2570 \pm 90 \mathrm{Ma}$ for a weakly deformed megacrystic granodiorite near Mârmorilik, whilst Andersen \& Pulvertaft (1985) report an age of $2629 \pm 246$ Ma for a biotite gneiss (the main gneiss in Umanak Fjord) from Drygalski Halvø (fig. 2).

The currently best estimate of the age of the Rinkian is given by a $\mathrm{Rb}$-Sr isochron age of $1860 \pm 25 \mathrm{Ma}$ on the Prøven charnockite (Kalsbeek, 1981), which was intruded into metasediments already metamorphosed during the Rinkian, and which itself has a weakly metamorphic fabric (Kalsbeek, 1981).

As far north as Rink Isbræe the basement is mainly metamorphosed in amphibolite facies, whilst the supracrustal cover is typically in upper greenschist facies. Between Upernavik and Ussing Isfjord granulite facies predominates in both. A small area of early (probably Archaean) granulite facies gneiss on the island Ikerasak in Umanak Fjord (fig. 2) is the only locality of granulite facies in the main gneiss reported from the Umanak district (Grocott, 1981, 1982). The metabasite bodies, which are the subject of the present paper, are most easily accessible in areas with a low to moderate relief. They were subjected to detailed investigations in two minor areas in the Umanak Fjord area (fig. 2). 


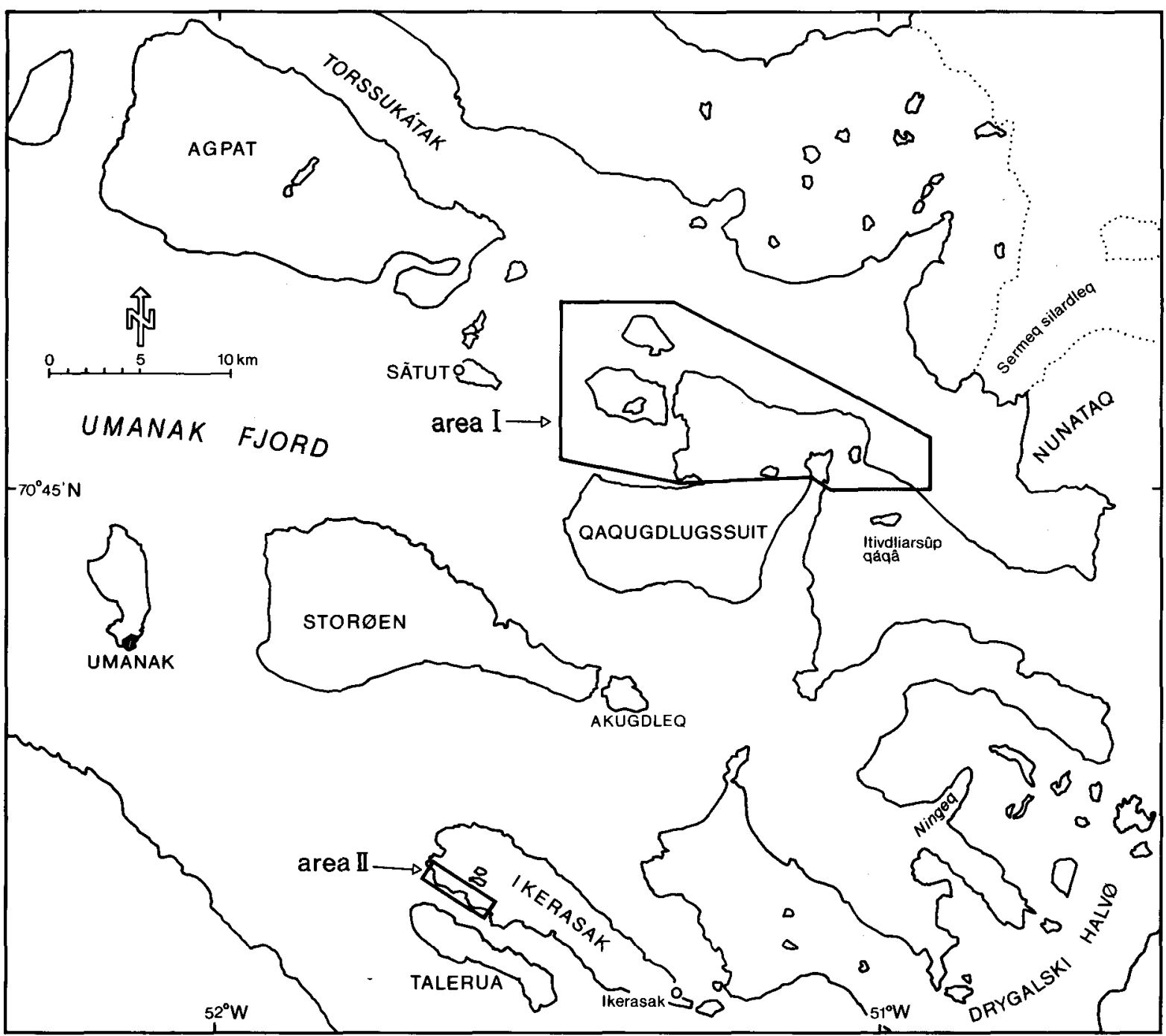

Fig. 2. Map of inner part of Umanak Fjord, with location of the two areas where metabasite bodies have been investigated in detail.

\section{Field relations of metabasite bodies}

\section{Main field occurrence}

Fig. 3 shows the field appearance of a typical metabasite body. Usually metabasite bodies are tabular or pod-like, but more irregular shapes also occur. They may be several hundreds of metres long, but the thickness generally does not exceed $25-30 \mathrm{~m}$. The $200 \mathrm{~m}$ thick intrusion on Ikerasak is in this respect an exception. Large intrusions often create dip-slopes, so they seem more impressive than they actually are.
Most metabasite bodies are pseudo-concordant, that is at a distance they seem to be parallel to the main structural pattern in the basement, whilst on closer inspection they can be shown to cut migmatitic structures in the gneiss at a small angle. There are, however, large variations in the degree of discordancy. The contact may change from nearly perfect parallelism (fig. 4) to a clearly cross-cutting relationship to the gneiss (fig. 5), within one and the same intrusion. Fig. 6 shows an extreme example of parallelism between a pinch-and- 


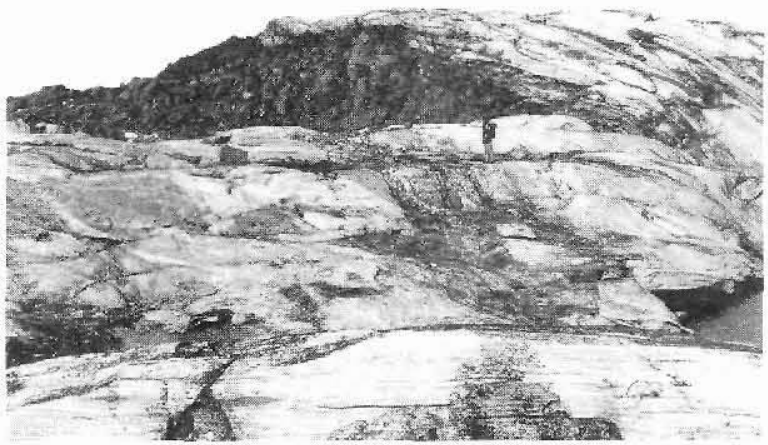

Fig. 3. Typical field appearance of a discordant metabasite body. Person for scalc in the foreground.

swell metabasite body and platy high-strain gneiss. Central parts of swells have retained their igneous mineralogy, whilst pinches and marginal parts of swells in this example possess a completely metamorphic fabric and mineralogy. It is uncertain whether the pinch-and-swell structure is entirely deformational or whether it reflects primary variations in thickness.

Two contrasting types of termination are demonstrated by metabasite bodies shown in fig. 7 . At blunt ends pegmatite is common, and the gneiss may be scar folded. Lithological layering in the metabasite body itself is abruptly cut off. This type of termination is

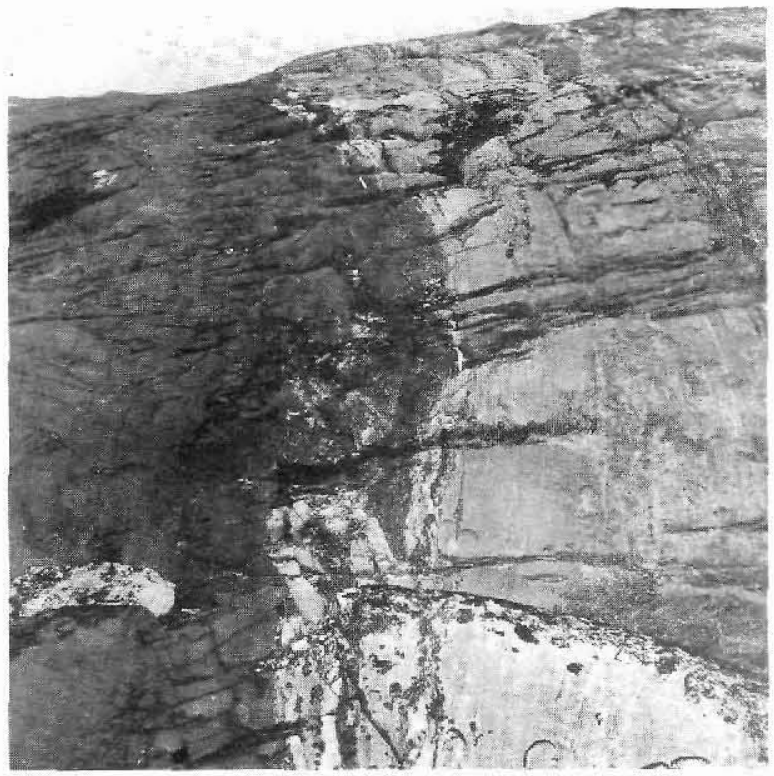

Fig. 4. Contact between gneiss and metabasite body parallel to gneiss foliation on the island Ikerasak (area II).

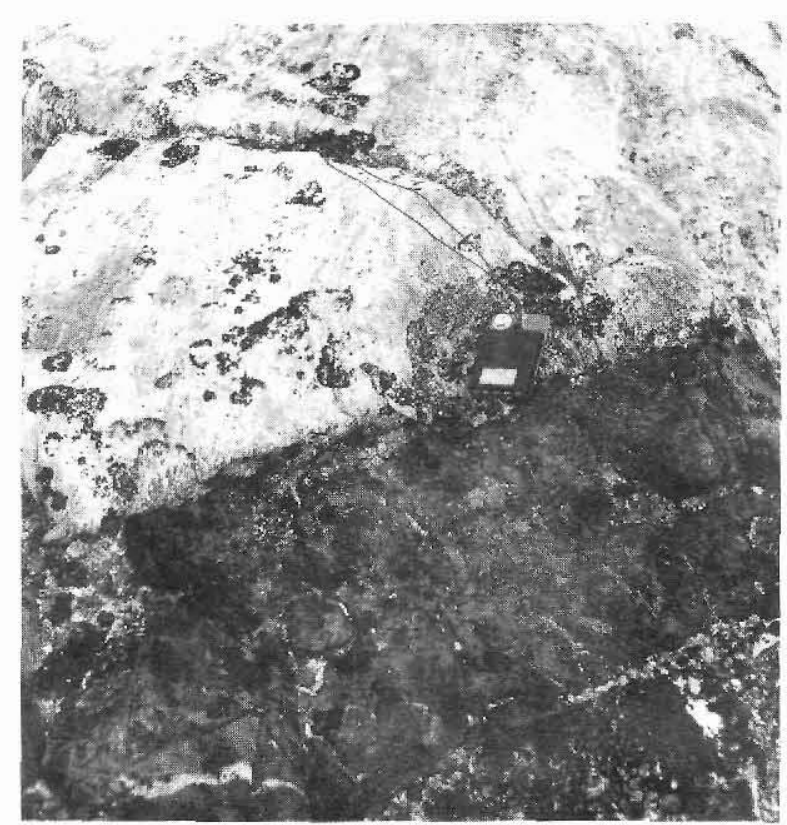

Fig. 5. Apophysis of metabasite body shown in fig. 4 crosscutting gneiss foliation at a high angle.

thought to be due to boudinage. The metabasite bodies may, however, also wedge out in the gneiss. Where igneous textures are preserved right to the very tip of such terminations, the wedging-out is believed to be a primary feature.

The fact that the metabasite bodies are layered intrusions is most easily demonstrated in area I (fig. 2) where many metabasite bodies are each divided into an ultrabasic/picritic and a gabbro-noritic layer. The ultrabasic/picritic layer is much darker than the gabbro-noritic one, sometimes enabling one to distinguish the two zones at a distance of several hundred metres. Whilst the contact between gneiss and ultrabasite/picrite is al-

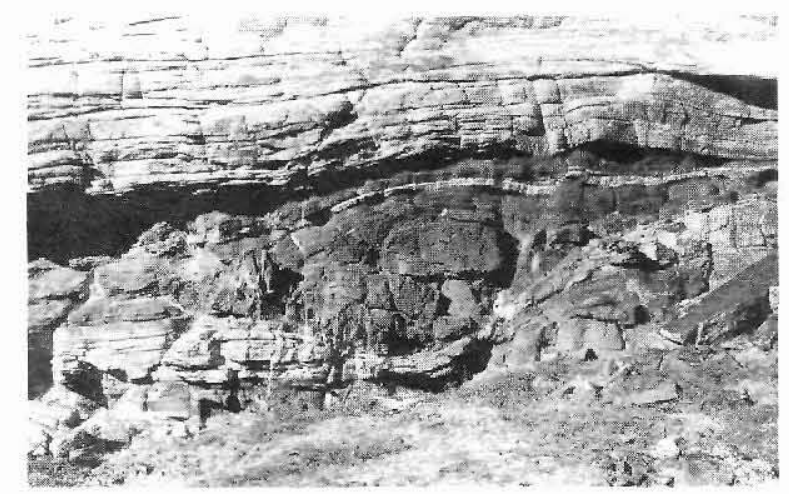

Fig. 6. Pinch-and-swell metabasite body in high strain gneiss in Oôroq qiterdleq (area I, mainland). 


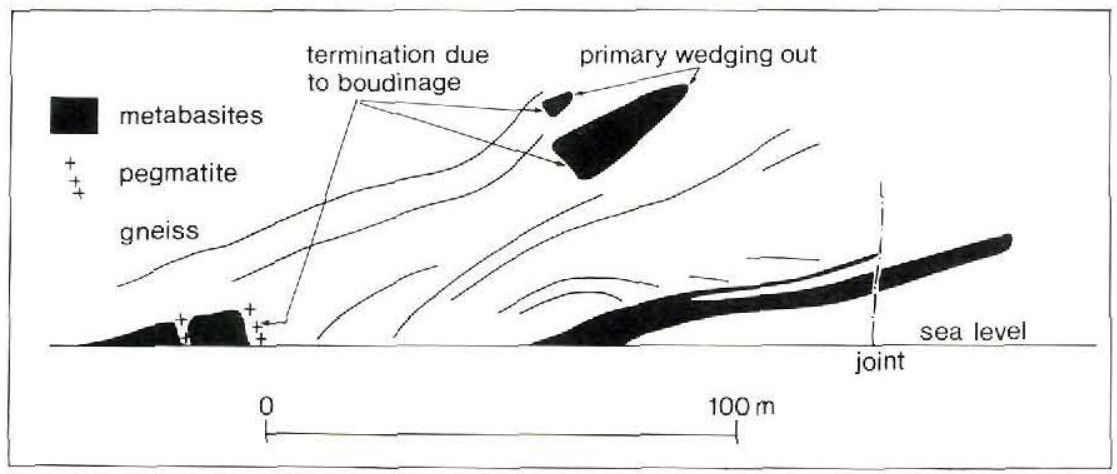

Fig. 7. Sketch of metabasite bodies on steep wall north of Qingup qáqâ (area I, mainland).

ways sharp, the gabbro-norite may show a blurred contact to the gneiss. The gneiss itself is unfoliated and granitic within a zone of $5-10 \mathrm{~cm}$ from the metabasite body, possible indications of having been near melting temperatures. The contacts of metabasite bodies on Ikerasak (area II, fig. 2) are always knife sharp.

Larger metabasite bodies have usually retained their igneous texture and an essentially dry mineral assemblage, and wet metamorphic parageneses are restricted to border zones a few centimetres thick. However, when metabasite bodies have been subjected to high amounts of post-intrusion deformation, their mineralogy and fabric may be entirely metamorphic.

\section{The significance of folded metabasite bodies}

Fig. 8 is a simplified geological map of area $\mathrm{I}$, the northernmost of the areas where metabasite bodies were studied in detail. In the eastern part of this area a unit of augen gneiss, amphibolite and associated rocks of possible supracrustal origin delineate a homoaxial isoclinal double fold pattern on a $\mathrm{N}-\mathrm{S}$ trending axis. Axes of small scale isoclinal folds within the unit generally parallel the main $\mathrm{N}-\mathrm{S}$ axial direction. In addition $\mathrm{N}-\mathrm{S}$ trending axes are measured in platy high strain gneiss and agmatised amphibolites in the immediate proximity of the unit. Proceeding to the west, however, a structurally lower level is reached, characterised by isoclinal folds on $\mathrm{E}-\mathrm{W}$ trending axes. The two levels are

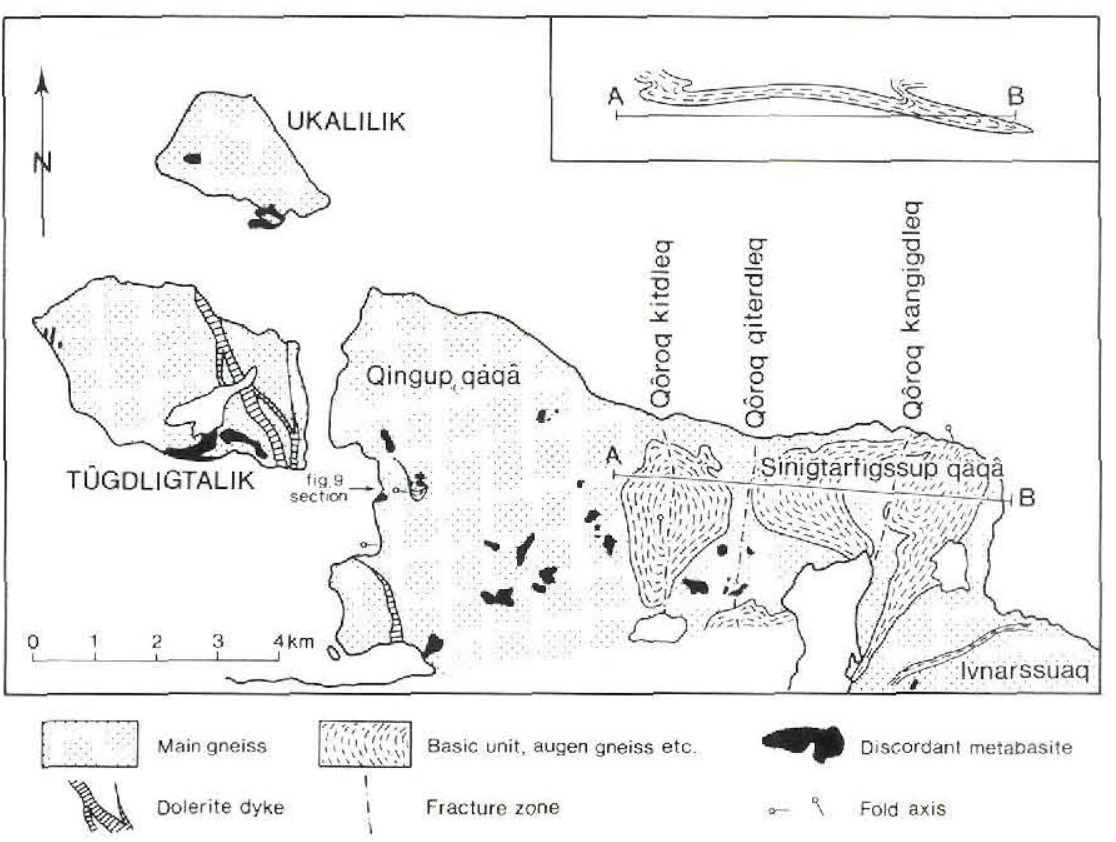

Fig. 8. Simplified geological map of area I. The homoaxial double fold pattern displayed by the basic unit and augen gneiss is shown schematically, with A-B as the line of section. Arrow indicates the location of the section across folded metabasite bodies on the south-western slope of Qingup qáqâ, shown in fig. 9 . 


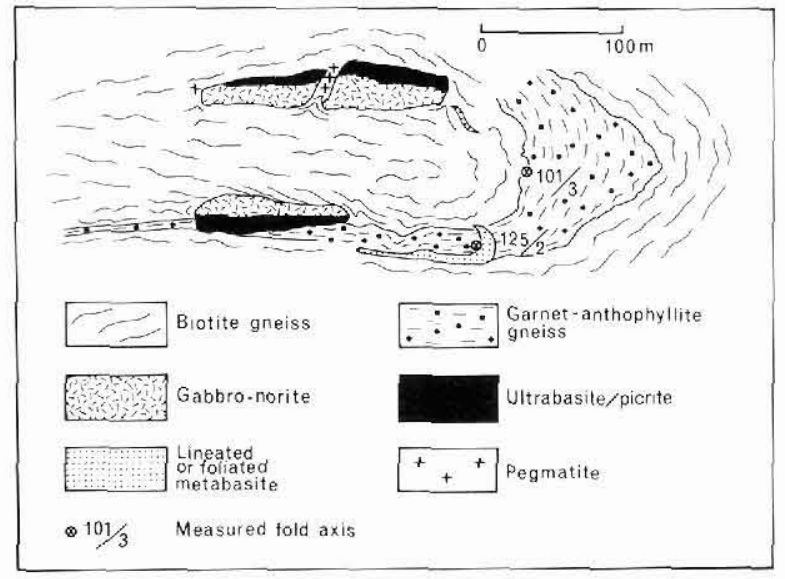

Fig. 9. Sketch map of the metabasite bodies affected by folding on Qingup qáqâ (location, fig. 8). The section is approximately perpendicular to the fold axis (after Schiøtte, 1981).

separated by less than $100 \mathrm{~m}$ of monotonous biotite gneiss with leucocratic veins, without discernible fold structures. Apparently the two fold directions are entirely restricted to each their own structural level and do not interfere with each other.

It was early realised (Schiøtte, 1981) that metabasite bodies in the lowermost level to the west were folded. Due to their internal igneous layering it is possible to distinguish bodies that are inverted in relation to one another by recumbent folding. Occasionally metabasite bodies with folded border zones or entirely fold shaped metabasite bodies occur. Large scale folding of metabasite bodies is demonstrated in figs 9 and 10 from the south-western slope of Qíngup qáqâ and north-western Tûgdligtalik respectively. The slight difference in the direction of fold axes measured in the gneiss and metabasite body on fig. 9 is attributed to the primary discordance between the rocks. If the ultrabasic/picritic zone is the earliest and lowermost cumulate in a metabasite body, as shown in the present paper, the fold structure described by metabasite bodies in fig. 9 is a recumbent syncline.

Boudinage of metabasite bodies appears to be a feature which developed on the flanks of the isoclinal folds. The large metabasite body on western Qingup qáqâ (fig. 8) one kilometre north of the fold closure locality in fig. 9 has the ultrabasic/picritic zone on its upper side. If it is directly connected with the folded metabasite bodies, it belongs to the upper limb of the fold structure, and the situation suggests boudinage with separation on a scale of several hundred metres.

In the uppermost structural level in the eastern part of area I the relation between basic intrusions and recumbent folding is less obvious. It is nowhere as clearly revealed as in figs 9 and 10 . However, metabasite bodies still have the appearence of boudins indicating that they were involved in a folding event. Individual bodies

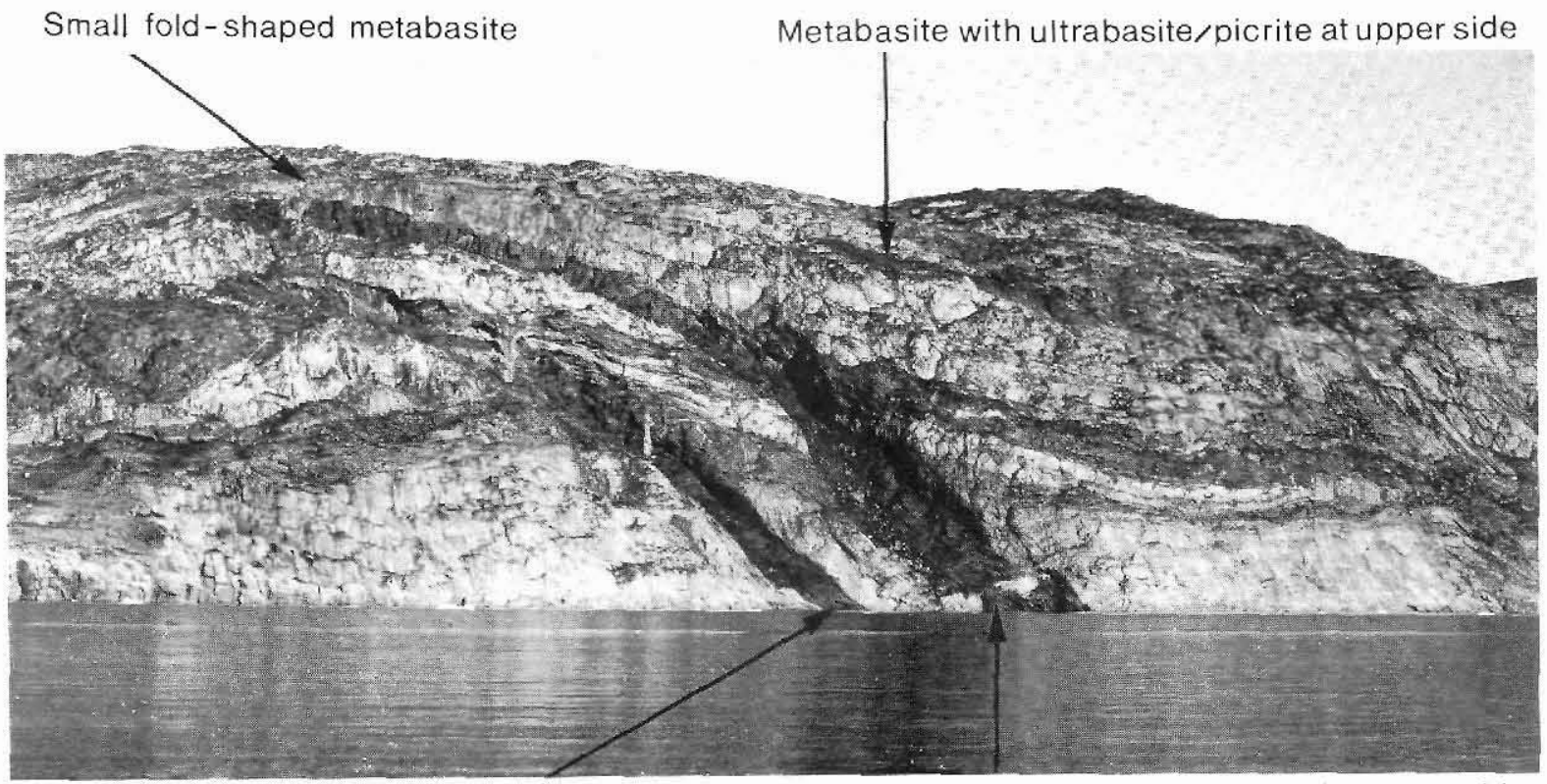

Entirely gabbro-noritic metabasite

Metabasite with ultrabasite/picrite at the lower side

Fig. 10. Metabasite bodies affected by folding on north-western Tûgdligtalik. Note the large angle between gneiss layering and metabasite bodies on the lower limb of the fold structure. 
within a neighbourhood often have similar orientations, but a confusing conglomeration of rotated boudins is found immediately west of the folded complex of basic unit and augen gneiss in fig. 8 . None of these metabasite bodies cuts across small-scale folds on $\mathrm{N}-\mathrm{S}$ trending axes in the gneiss. It thus seems reasonable to suggest that this metabasite 'swarm' owes its confusing pattern of rotated boudins to folding at the same time as the folding of the augen gneiss and the basic unit on N-S trending axes.

On the whole both folding on N-S trending and $\mathrm{E}-\mathrm{W}$ trending axes seems to postdate the intrusion event. It is suggested that folding on $\mathrm{E}-\mathrm{W}$ trending and $\mathrm{N}-\mathrm{S}$ trending axes operated simultaneously at different tectonic levels. In any case the area shows a high degree of deformation which postdates metabasite intrusion. A large part of the deformation pattern in the basement prior to metabasite intrusion has been erased.

\section{The Ikerasak controversy}

The map fig. 11 shows the major structural domains on the island Ikerasak (area II, fig. 2) in the southern part of Umanak Fjord. The metabasite bodies studied are situated near the abandoned village Umanatsiaq on western Ikerasak. As apparent from the detail map (fig. 12), they are steep to vertical, slightly irregular bodies, the easternmost of which is horse-shoe shaped. Long edges of the metabasite bodies are mostly parallel to the gneiss layering, but discordances also occur. Thus the central metabasite body has a complicated system of thin apophyses which in some cases cut across gneiss layering at right angles.

In Grocott's interpretation $(1981,1982)$ the metabasite bodies on western Ikerasak were dykes (or possibly one dyke if the three major bodies link up in three dimensions) emplaced during or later than the final stages of a folding event, which itself is slightly younger than the development of the Ikerasak Shear Zone on the southern part of the island. Grocott regards the horse-shoe shape of the easternmost body as a primary feature and does not attach any particular significance to the fact that marginal zones may be folded (fig. 13) and that internal foliation zones (which in turn are folded as shown in fig. 14) occur.

In Grocott's fold chronology Z-shaped asymmetric folds within the country rock immediately east of the metabasite bodies are synchronous with development of the Ikerasak Shear Zone and thus predate dyke intrusion. Grocott admits that no metabasite body has been seen to actually cut these Z-shaped folds, but argues that red fractures emanating from a metabasite body termination cut across several deformational structures which are related to the folds.

In the present author's opinion Grocott's arguments for metabasite intrusion at a late stage in the structural evolution of the area are unconvincing. The red fracture zones could very well be young features with no direct relation to the intrusion event. The folded margins and internal strain zones show that the event of intrusion

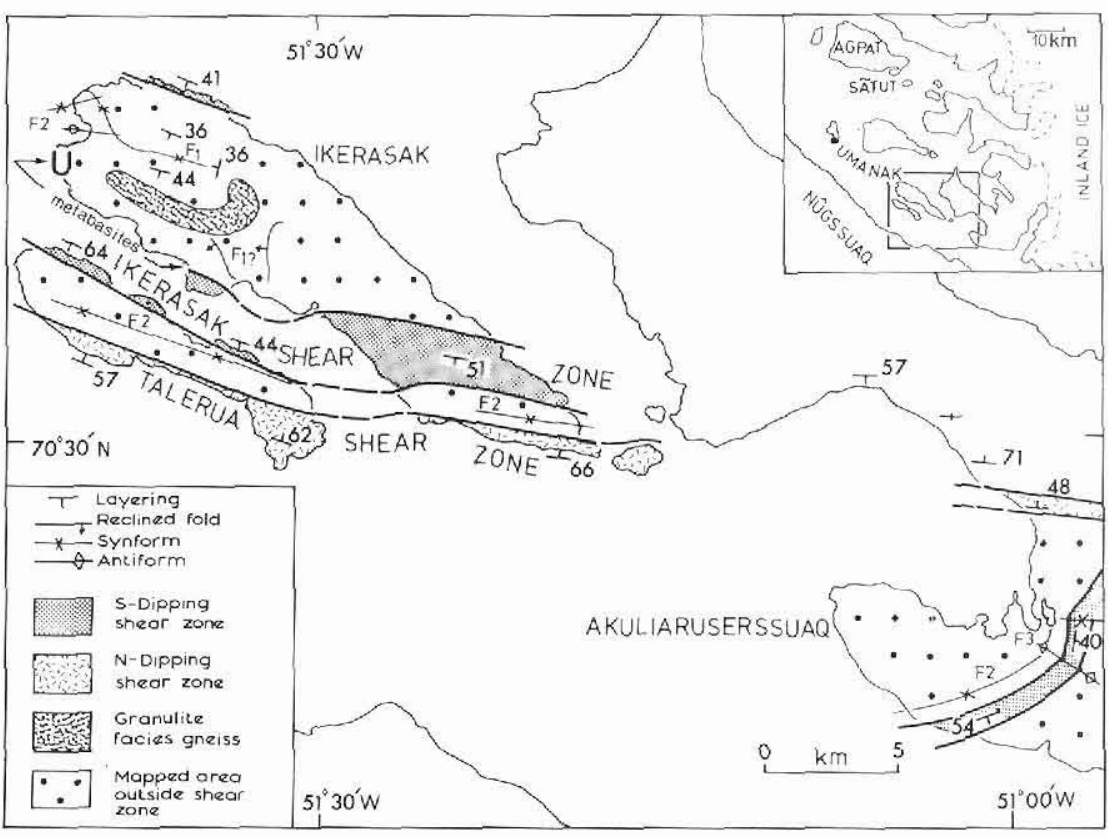

Fig. 11. Map of the Ikerasak area showing the structural domains. The section of coastline on western lkerasak shown on the detail map (fig. 12) is indicated by arrows. U: Ũmánatsiaq (after Grocott, 1981). 


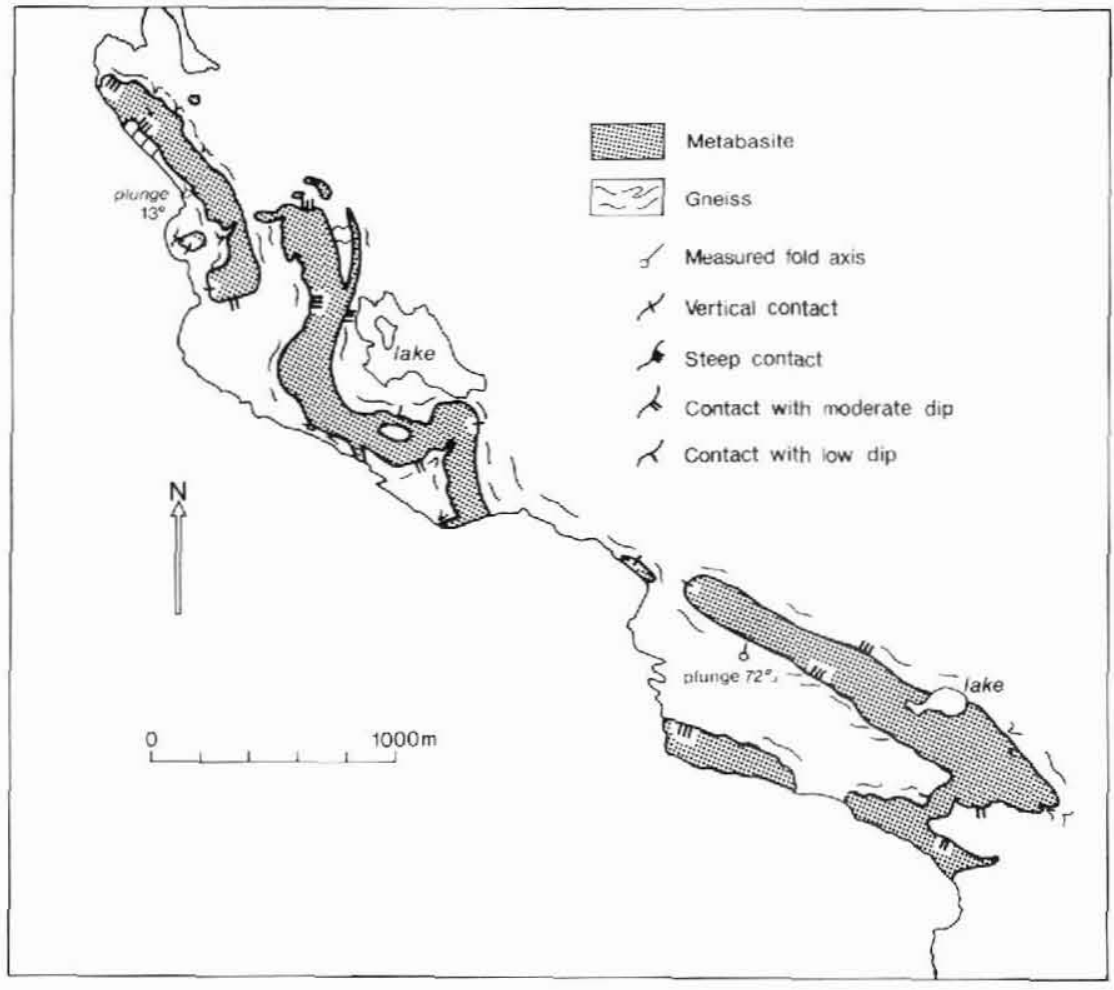

Fig. 12. Sketch map of metabasitc bodies near the abandoned village Ũmánatsiaq on Ikerasak (location, fig. 11).

predates at least one phase of folding, possibly the Z-shaped folds which are important structural features immediately east of the metabasite bodies. Moreover the chemical and petrographical trends across metabasite bodies (described in the following section) are reversed on the southern limb of the horse-shoe shaped metabasite body, showing that the horse-shoe shape is a true isoclinal fold structure.

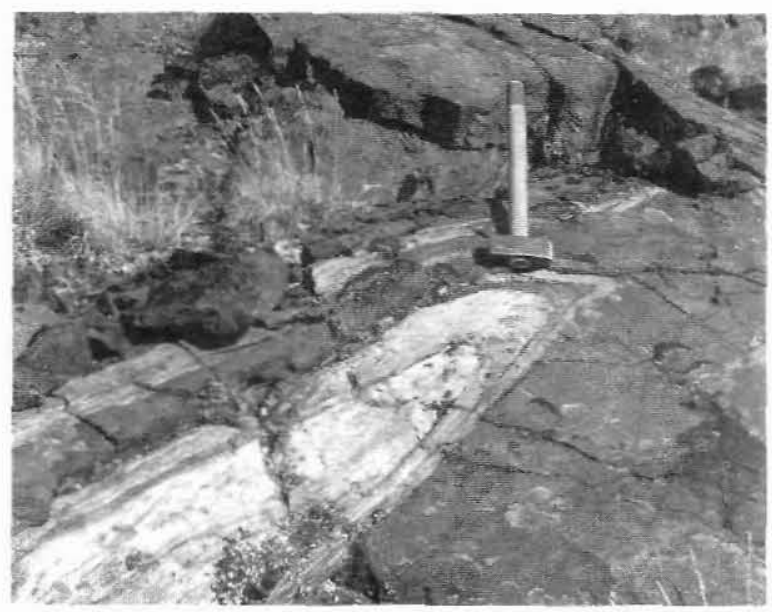

Fig. 13. Folded contact between metabasite body and gneiss near Ümánatsiaq on Ikerasak.
It will appear from the section dealing with petrology and geochemistry that metabasite bodies in areas I and II constitute a consanguinous suite of layered intrusions. Although the layering is less clearly revealed in the field in area II (Ikerasak), the metabasite bodies here are thought to be originally sill-like bodies owing their present steep position to later deformation.

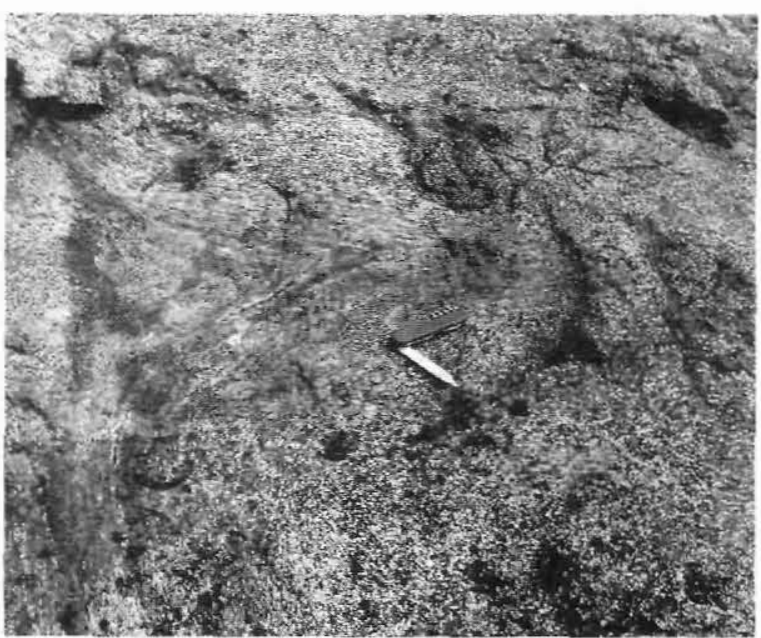

Fig. 14. Folded internal foljation zone in metabasite body near Umánatsiaq on Ikerasak. 


\section{Petrology and geochemistry of metabasite bodies}

The distribution of rock types across metabasite bodies in areas I and II is shown schematically in fig. 15. In area I an ultrabasic/picritic zone typically underlies a gabbro-noritic zone which in turn may be overlain by a less mafic garnet-biotite gabbroic zone. Ultrabasic/picritic lithologies are absent from area II where a gabbronoritic zone occupies the lowest part of the intrusion. In the overlying garnet-biotite gabbro zone a central subzone is sandwiched between two plagioclase-rich subzones, whilst a fine-grained clinopyroxene-rich subzone is developed at the upper contact.

Metabasite bodies outside areas I and II were only briefly investigated. Ultrabasic lithologies are rare or absent outside area I (T. C. R. Pulvertaft, C. Knudsen, M. C. Andersen and J. B. Jørgensen, personal communication), whilst garnet-bearing metabasite bodies are rather common on southern Drygalski Halvø (M. C. Andersen, personal communication). Gabbro-noritic lithologies occur in metabasite bodies throughout Umanak Fjord.

Due to the location of area II in the proximity of the Ikerasak Shear Zone, recrystallisation in amphibolite facies is generally more pervasive within metabasite bodies at this locality than in area I.

\section{Petrography}

\section{Early texture and mineralogy}

\section{Ultrabasiclpicritic zone}

Large oikocrysts of enstatitic orthopyroxene, sometimes exceeding $1 \mathrm{~cm}$ in diameter, enclosing olivine grains are a characteristic feature of this zone. These orthopyroxenes are generally plate-like whilst crystals with a prismatic habit become more common towards the gabbro-noritic zone. Due to a high content of submicroscopic inclusions orthopyroxenes may be dusty brown, sometimes nearly opaque.

Clinopyroxene occurs either as isolated grains or as domains within orthopyroxene plates. The colour is either green or dusty dark brown. Simultaneous extinction under crossed nicols of neighbouring clinopyroxene domains in orthopyroxene plates suggests that they link up in three dimensions. For both ortho- and clinopyroxene $\mathrm{Cr}$ contents may be as high as $12000 \mathrm{ppm}$.
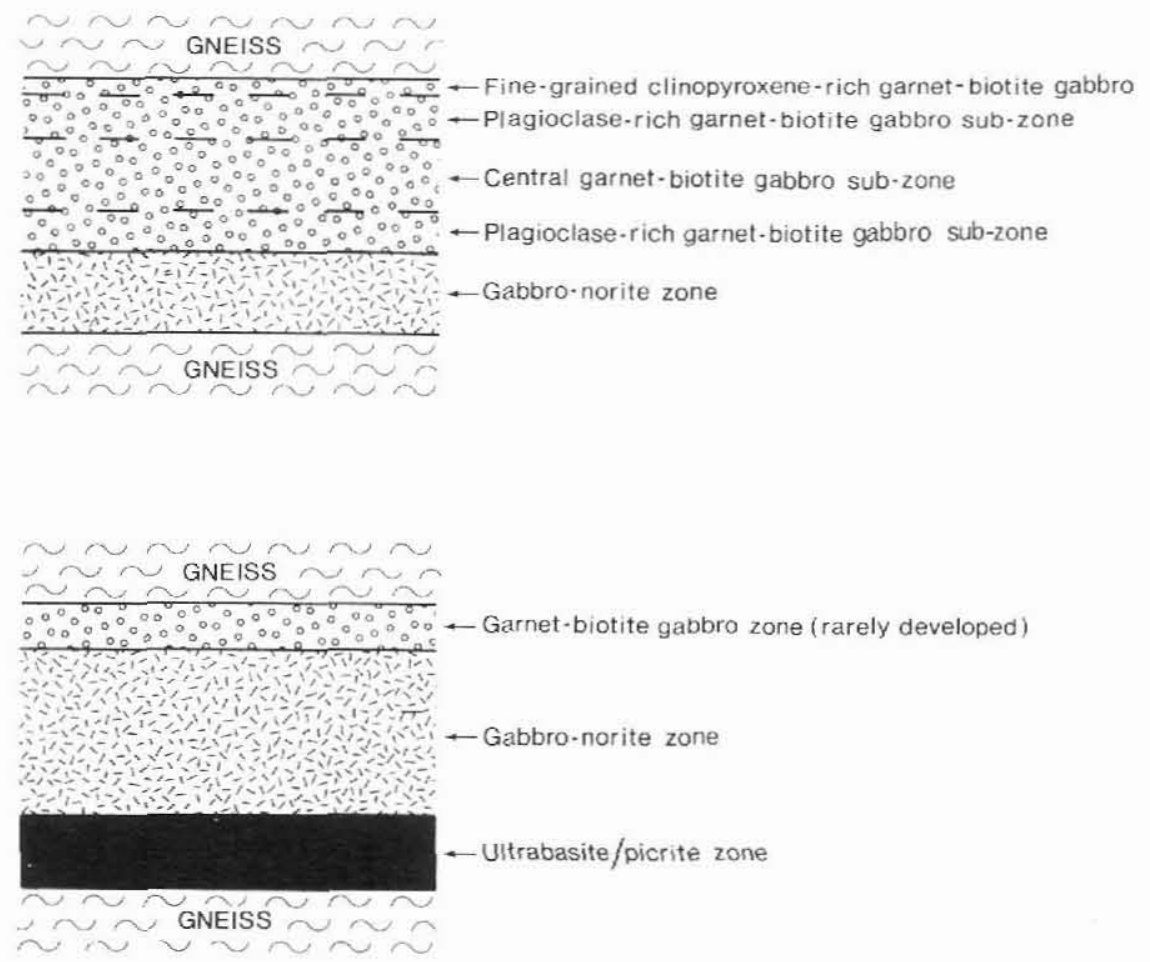

Fig. 15. Schematic distribution of rock types across metabasite bodies from area 1 (below) and area II (above). 
Olivine, usually ranging between $\mathrm{Fo}_{83}$ and $\mathrm{Fo}_{86}$, occurs as isolated grains or enclosed in pyroxene plates. The grain size is typically $0.5-1.0 \mathrm{~mm}$. Neighbouring olivine grains in orthopyroxene plates may extinguish simultaneously under crossed nicols.

Intergranular colourless to yellow and red pleochroic phlogopite may occur. The size of individual grains may exceed $1 \mathrm{~mm}$.

Cr-spinel (or chromite) may amount to more than $5 \%$. It is either intergranular or poikilitically enclosed in pyroxene, olivine or mica. The distribution is homogeneous, that is chromitite layers have not been found. Whilst enclosed $\mathrm{Cr}$-spinels are opaque, intergranular crystals are slightly transparent. The grain size is $0.05-$ $0.10 \mathrm{~mm}$.

Chalcopyrite and pyrrhotite amount to less than $0.1 \%$. They occur either isolated or enclosed in $\mathrm{Cr}$ spinel.

The main distinguishing feature between ultrabasic and picritic lithologies is the occurrence of about $10 \%$ cloudy plagioclase (fig. 16) within the latter. Sometimes there is a gradation from ultrabasite through picrite towards the gabbro-noritic zone. Due to the dark colour of the plagioclase, however, picrites are not easily distinguished from ultrabasites in the field.

In the scanning microscope the plagioclase clouding is seen to be caused by subhedral inclusions, mainly of spinel, in the $0.0005-0.0020 \mathrm{~mm}$ size range (fig. 17). These inclusions are either evenly distributed or aligned along planar structures (probably twin planes). Central parts of plagioclase grains are dark brown, whilst margins may be clear. Anorthite contents are strikingly low, mainly in the andesine range. Clear rims on cloudy

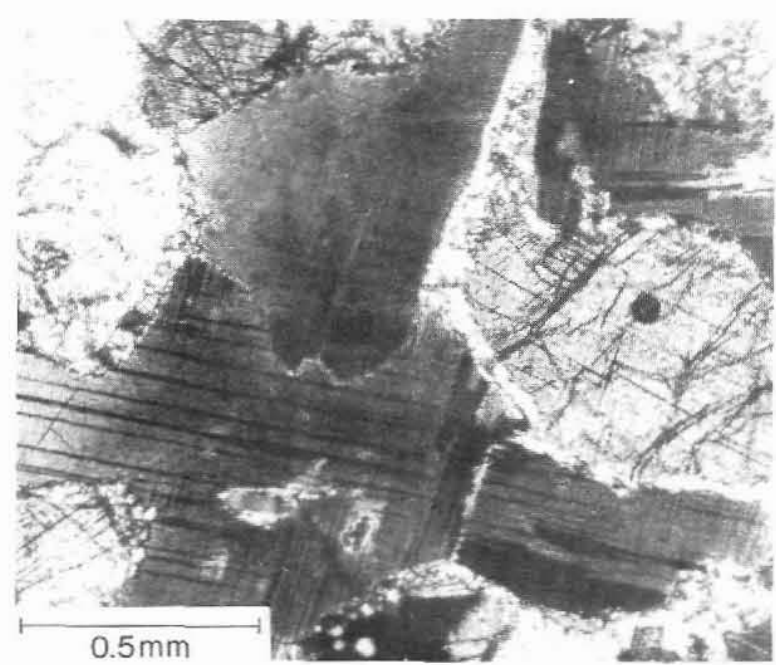

Fig. 16. Cloudy plagioclase in picrite zone of metabasite body (crossed polarisers).

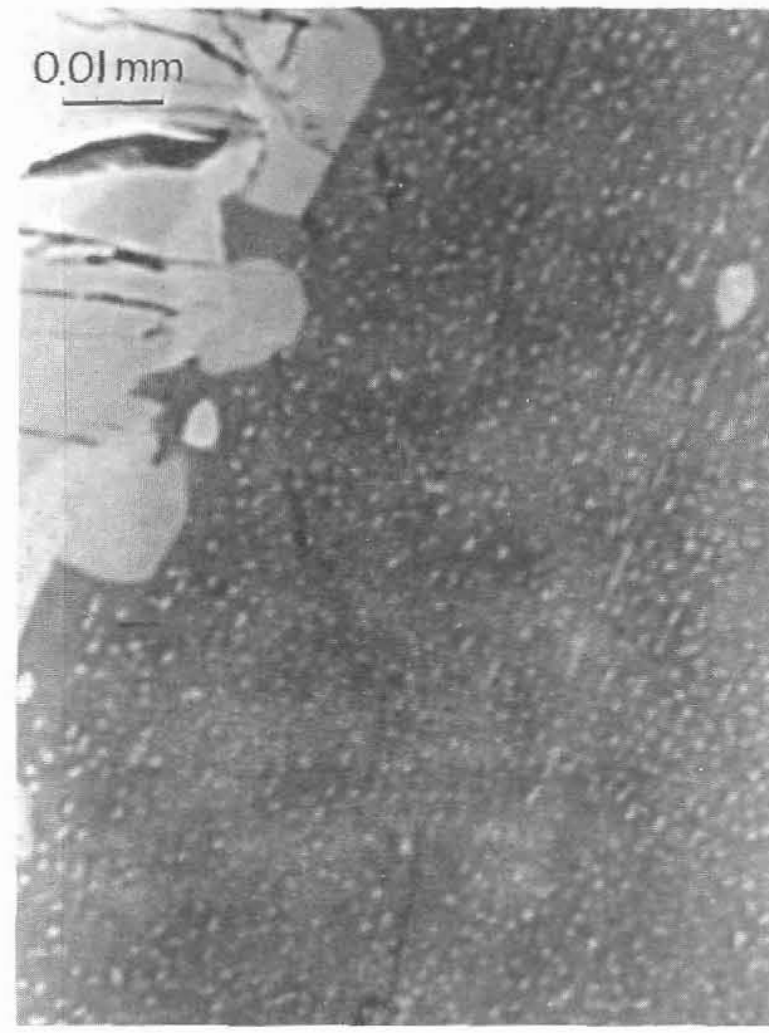

Fig. 17. Scanning micrograph of sub-microscopic spinel inclusions in plagioclase. Planar alignment of the spinel grains (probably along twin planes) is distinct to the right. To the left the plagioclase abuts a pyroxene grain.

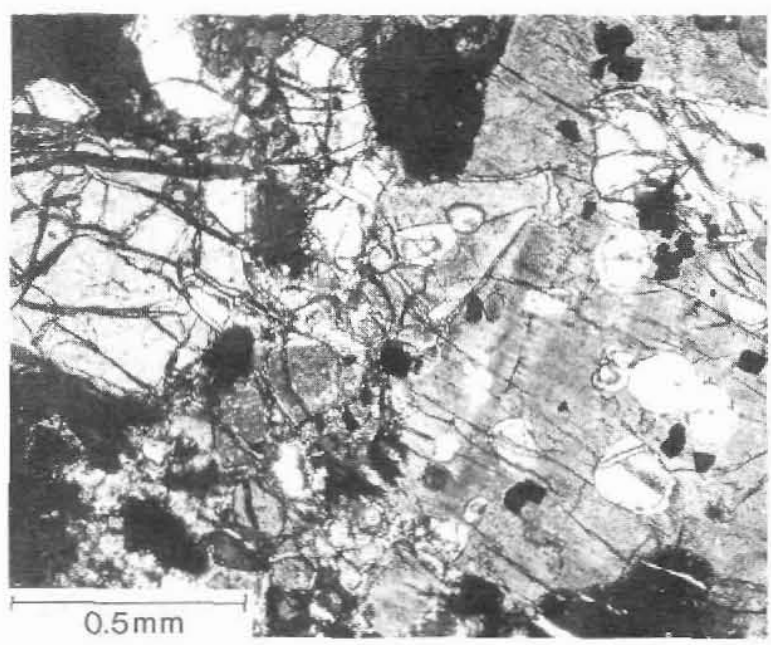

Fig. 18. Typical picrite texture. Orthopyroxene oikocryst encloses olivine and $\mathrm{Cr}$-spinel to the right. Isolated olivine grains and cloudy plagioclase dominate the left (crossed polarisers). 
plagioclase may even be oligoclase. Away from the clear rims chemical analyses have shown high contents of $\mathrm{MgO}$ and $\mathrm{FeO}^{\mathrm{T}}$, which may each exceed 3 weight percent.

A typical picrite texture is shown in fig. 18. The dark plagioclase is mainly interstitial between grains of olivine, but may also occur enclosed in pyroxene oikocrysts. A $0.05-0.10 \mathrm{~mm}$ thick double corona of very fine-grained bladed material usually occupies a reaction zone between olivine and cloudy plagioclase. In some cases it can be seen to have grown at the expense of fine-grained pyroxene. This suggests complicated intergranular reactions which will be further dealt with under metamorphic effects.

The ultrabasic/picritic zone grades into gabbro-norite through a $10 \mathrm{~cm}$ wide transitional zone where olivine is scarce and less $\mathrm{Mg}$-rich (about $\mathrm{Fo}_{78}$ ). Dusty pyroxenes and cloudy plagioclase are superseded by clear crystals.

\section{Gabbro-noritic zone}

This zone is devoid of olivine and cloudy plagioclase. Pyroxenes are only faintly coloured or colourless. Apart from the very occasional occurrence of $<0.01 \mathrm{~mm}$ large chromite grains (only identified with certainty in one case) which are likely to be metamorphic segregations in $\mathrm{Cr}$-rich pyroxenes, $\mathrm{Cr}$-spinel or chromite is absent.

Medium-grained euhedral to subhedral prismatic orthopyroxene amounts to $55-70 \%$. Clinopyroxene usually constitutes about $5 \%$. It is found as isolated grains as well as in continuous intergrowth with orthopyroxenc. Pronounced exsolution of orthopyroxene in clinopyroxene and a somewhat more restricted exsolution of

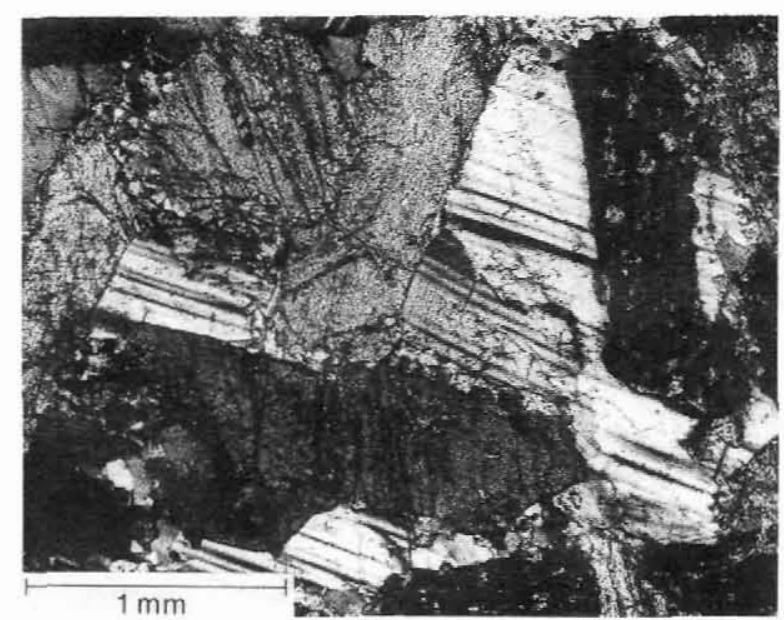

Fig. 19. Gabbro-norite texture. Framework of prismatic orthopyroxene and subordinate clinopyroxene with interstitial plagioclase (crossed polarisers). clinopyroxene in orthopyroxene gives rise to a lamellae pattern. Occasionally domain-like exsolution may be seen. Compositionally the pyroxenes are bronzite and diopside respectively, with $\mathrm{Cr}$ contents as high as 7000 ppm.

Fig. 19 shows a typical gabbro-norite texture. The pyroxene grains tend to build up a framework with interstitial plagioclase. The plagioclase is either fine grained or occurs as larger crystals continuous between adjacent interstices in the pyroxene framework. Only in the upper part of the gabbro-norite zone, where it becomes transitional to garnet-biotite gabbro, may plagioclase occur as elongate laths. Interstitial plagioclase is labradoritic $\left(\mathrm{An}_{51-65}\right)$. About $1 \%$ biotite together with minor quartz, aggregates of rutile and ilmenite (often enclosed in biotite), sulphides (dominantly pyrrhotite), apatite and sometimes a very fine-grained hornblende fill out the smaller interstices. Sometimes biotite-pyroxene intergrowths are seen. Very occasionally a myrmekitic intergrowth of plagioclase and quartz is found.

\section{Garnet-biotite gabbroic zone}

This zone is most extensively developed on Ikerasak (area II, fig. 2) where there are three distinct lithologies.

Plagioclase-rich sub-zone. Immediately adjoining the gabbro-noritic zone (which represents the lower part of the intrusion) a zone of probable plagioclase enrichment is found. Medium-grained elongate laths of plagioclase amount to about $60 \%$. With anorthite contents as high as $68 \%$ these plagioclase grains are the most anorthite-rich found in the whole suite.

Interstitial pyroxene only amounts to $20-25 \%$. Ortho- and clinopyroxene have mutually exsolved in lamellae or domains. Due to these exsolution patterns it is difficult to estimate the relative proportions of orthoand clinopyroxene, but the latter is the dominant. The pyroxenes are hypersthene and salite (according to the classification scheme of Deer et al., 1978) with maximal $\mathrm{Cr}$ contents of only a few hundred parts per million. The occurrence of chemically evolved interstitial pyroxenes together with a primitive cumulus plagioclase is the mirror image of what was seen in the gabbro-noritic zone.

Garnet amounts to $5-10 \%$ in this sub-zone, usually occurring as reaction rims between plagioclase and pyroxene (fig. 20). Biotite with poikilitically enclosed aggregates of rutile and ilmenite amounts to $2-5 \%$, occurring mainly as stellate aggregates in association with quartz, apatite, fine-grained hornblende and pyrrhotite. Myrmekite is very occasionally found in the proximity of garnet. 


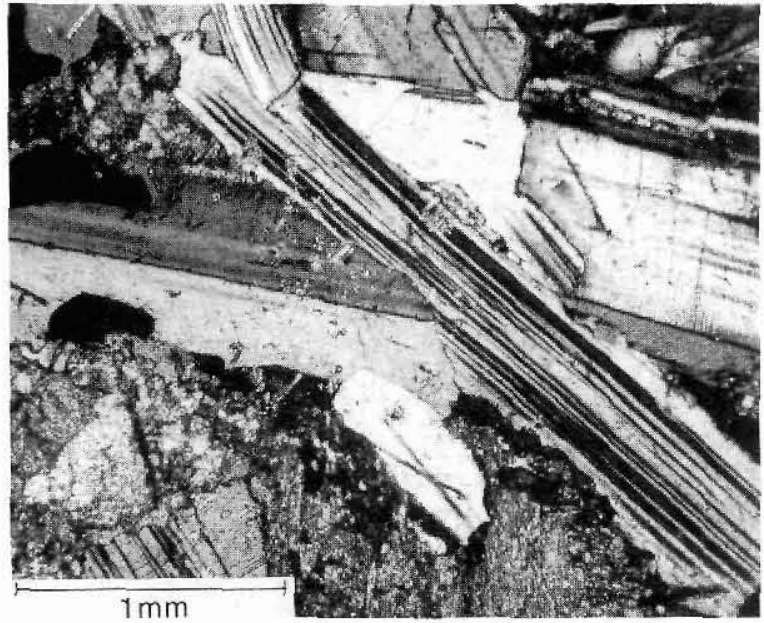

Fig. 20. Texture of the plagioclase-rich sub-zone of garnetbiotite gabbro from a metabasite body on Ikerasak. The dark mineral upper left is garnet occurring in a reaction zone between plagioclase and pyroxene (crossed polarisers).

Central sub-zone. Roughly equal amounts of plagioclase and mafic minerals are found in the central part of the garnet-biotite gabbro zone. Rather fine-grained subhedral pyroxenes together with small amounts of very fine-grained hornblende, biotite (as stellate aggregates), rutile-ilmenite aggregates, pyrrhotite and apatite are separated from interstitial plagioclase by a garnet reaction zone (fig. 21). A less than $0.01 \mathrm{~mm}$ thick zone

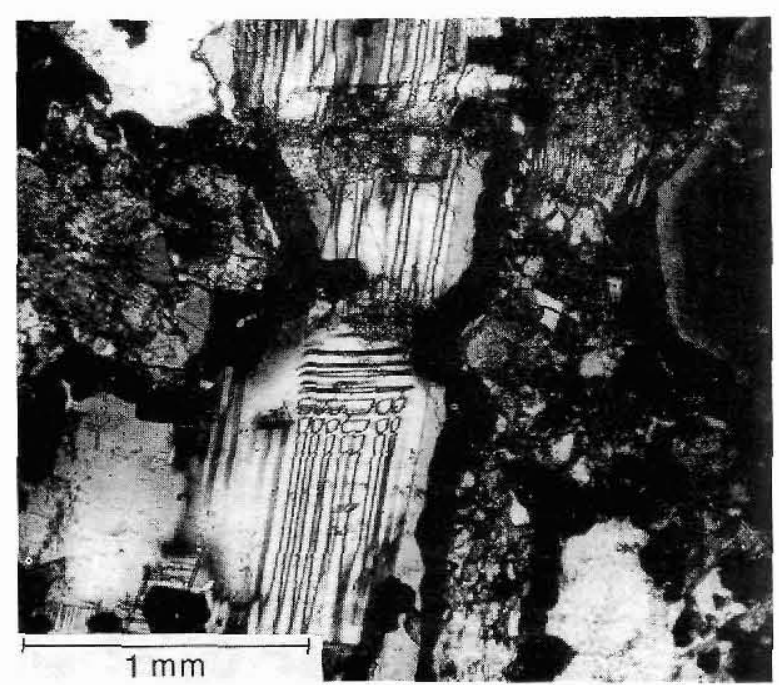

Fig. 21. Texture of the central part of the garnet-biotite gabbro zone of a metabasite body on Ikerasak. Garnet occurs as a corona around plagioclase. The bright rim separating garnet and plagioclase to the right is quartz (crossed polarisers).

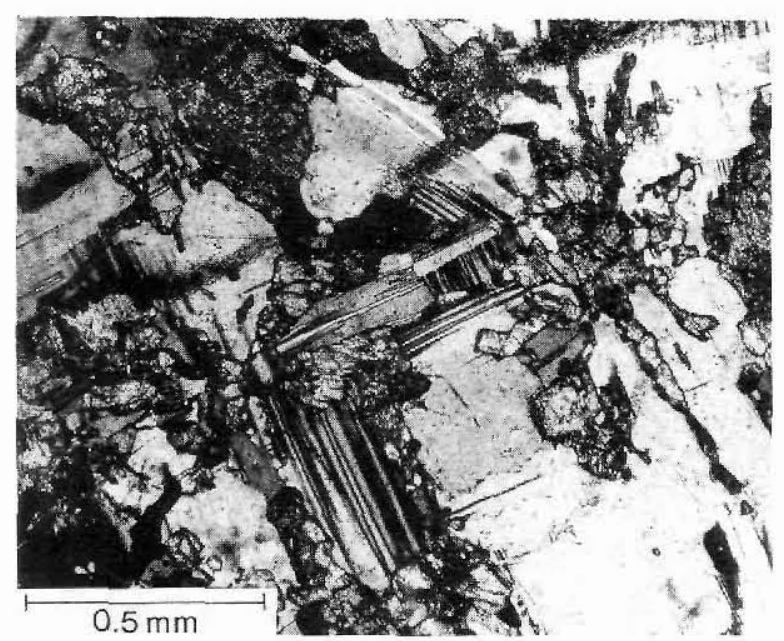

Fig. 22. Texture of the marginal facies of a metabasite body on Ikerasak. A fine-grained network of clinopyroxene (the highrelief mincral) with the intervening space occupied by plagioclase (crossed nicols).

of quartz separates plagioclase and garnet in the right part of fig. 21. Myrmekite may occur.

Due to the mutual exsolution of ortho- and clinopyroxene their relative proportions are still difficult to estimate, but the former probably does not exceed 5\%. They are the least Mg-rich pyroxenes in the rock suite, however still in the hypersthene and salite ranges. Anorthite contents of plagioclase do not exceed $60 \%$.

Fine-grained clinopyroxene-rich sub-zone. Proceeding from the central part of the intrusion towards the originally upper contact an additional plagioclase-rich sub-zone occurs before the outermost $50 \mathrm{~cm}$ thick finegrained margin is reached (fig. 22). Apart from its grain size its main distinguishing feature is that it appears to be a concentration zone for clinopyroxene which amounts to about $40 \%$, occurring as needle-like or prismatic grains building up a network. In terms of $\mathrm{Mg}$ and $\mathrm{Cr}$ contents they are intermediate between the cumulus pyroxenes in the gabbro-noritic zone and the interstitial pyroxenes in the plagioclase-rich and central sub-zones. Thus whereas $\mathrm{Cr}$ contents of the interstitial pyroxenes never exceed a few hundred parts per million, they may be as high as $1500 \mathrm{ppm}$ in pyroxenes from the marginal facies. Anorthite contents of plagioclase are about $60 \%$.

\section{Metamorphic effects}

The description of igneous and metamorphic features cannot be kept entirely separate. In the foregoing section mineral assemblages preserving igneous texture were described, but strictly speaking the cloudy plagio- 
1. Igneous minerals

Olivine, Cr-spinel, orthopyroxene, clinopyroxene, plagioclase, quartz, Fe-Ti oxides, sulphides, apatite, biotite (?), hornblende (?).

2. Early, essentially dry and static metamorphism

Re-equilibration of igneous minerals including mutual exsolution of orthopyroxene and clinopyroxene. In olivine-bearing rocks growth of minute spinel crystals in plagioclase. Garnet growth at the expense of plagioclase in felsic rocks. Growth of platy pyroxene oikocrysts in picritic and ultrabasic rocks. Growth of early biotite (?) and hornblende (?).

Late stage of static or early stage of dynamic metamorphism

Growth of fine bladed double coronae between olivine and spinel clouded plagioclase. Further re-equilibration of earlier mineral assemblages. In situ replacement of pyroxenes by actinolite. Growth of minute hornblende at pyroxene-plagioclase contacts. Earliest generation of biotite (?).

3. Later, essentially dynamic amphibolite facies metamorphism

Breakdown of last igneous minerals. Growth of pale to deep green hornblende at the expense of earlier amphiboles, accompanied by cummingtonite in rocks of certain bulk compositions. Plagioclase neoblastesis in gabbro-norite and garnet-biotite gabbro. Growth of sphene and garnet in rocks of certain bulk compositions. Growth of late biotite, particularly in alkali metasomatised rocks. Oxide re-equilibration and neoblastesis.

4. Retrogressive metamorphism in greenschist facies

Growth of serpentine (on olivine), chlorite (on biotite), sericite and epidote (on plagioclase).

clase and the garnet are metamorphic phases. A treatment of the earliest dry metamorphism follows together with the later overprint of amphibolite and greenschist facies metamorphism and their effects on mineral chemistry. A synthesis of the successive stages of re-equilibration and recrystallisation which have affected metabasite bodies is presented in Table 1 .

\section{Re-equilibration of igneous olivine and Cr-spinel}

Re-equilibration of igneous olivine and $\mathrm{Cr}$-spinel are among the earliest metamorphic effects. Considering the high contents of $\mathrm{Cr}$ in the olivine-bearing ultrabasic/ picritic zone and assuming a crystal/liquid partition coefficient near unity for $\mathrm{Cr}$ in olivine (suggested among others by Schreiber (1976) and Schreiber \& Haskin (1976)), the Cr contents of olivine in Table 2 are clearly too low to be accounted for in terms of igneous equilibrium. Metamorphic re-equilibration has taken place. Cr-spinel enclosed in olivine probably developed towards higher $\mathrm{Cr}$ contents.

Microprobe analyses of $\mathrm{Cr}$-spinels fall in two groups (fig. 23, Table 3). Within the same rock sample, transparent intergranular $\mathrm{Cr}$-spinels have higher $\mathrm{Mg} /(\mathrm{Mg}+$ $\mathrm{Fe}^{\mathrm{T}}$ ) and lower $\mathrm{Cr} / \mathrm{Al}$ ratios than opaque $\mathrm{Cr}$-spinels enclosed in mafic silicate phases. The most $\mathrm{Cr}$-rich spinels from the latter group are true chromites (according to the classification scheme of Stevens, 1944).
Table 2. Olivine from the metabasite bodies

\begin{tabular}{lrr}
\hline & 1 & \multicolumn{1}{c}{2} \\
\hline $\mathrm{SiO}_{2}$ & 40.54 & 38.93 \\
$\mathrm{TiO}_{2}$ & 0.00 & 0.01 \\
$\mathrm{Al}_{2} \mathrm{O}_{3}$ & 0.03 & 0.02 \\
$\mathrm{Cr}_{2} \mathrm{O}_{3}$ & 0.01 & 0.02 \\
$\mathrm{FeO}^{\mathrm{T}}$ & 13.77 & 20.65 \\
$\mathrm{MnO}$ & 0.14 & 0.27 \\
$\mathrm{NiO}$ & 0.46 & 0.42 \\
$\mathrm{MgO}$ & 47.06 & 40.81 \\
$\mathrm{CaO}$ & 0.06 & 0.00 \\
& 102.07 & 101.13
\end{tabular}

\begin{tabular}{lcc} 
Structural formulae (based on 4 oxygens) & \\
$\mathrm{Si}$ & 0.988 & 0.993 \\
$\mathrm{Al}$ & 0.001 & 0.001 \\
$\mathrm{Fe}^{3+}$ & 0.023 & 0.013 \\
$\mathrm{Fe}^{2+}$ & 0.259 & 0.428 \\
$\mathrm{Mg}$ & 1.715 & 1.551 \\
$\mathrm{Ni}$ & 0.009 & 0.008 \\
$\mathrm{Mn}$ & 0.003 & 0.006 \\
$\mathrm{Ca}$ & 0.002 & - \\
$\mathrm{Fo}$ & 86.9 & 78.4 \\
\hline
\end{tabular}

1. Central part of isolated olivine grain (that is not enclosed in pyroxene) in picrite 267435 , southern Tûgdligtalik (area I).

2. Central part of isolated olivine grain from a transitional zone between gabbro-norite and picrite 267436 , southern Tûgdligtalik (area I). 
Table 3. Cr-spinel from the metabasite bodies

\begin{tabular}{lrrrrr}
\hline & 1 & 2 & 3 & \multicolumn{1}{c}{4} & \multicolumn{1}{c}{5} \\
\hline $\mathrm{SiO}_{2}$ & 0.00 & 0.18 & 0.09 & 0.00 & 0.16 \\
$\mathrm{TiO}_{2}$ & 0.43 & 0.40 & 0.30 & 0.19 & 0.44 \\
$\mathrm{Al}_{2} \mathrm{O}_{3}$ & 17.13 & 20.99 & 27.13 & 36.19 & 31.36 \\
$\mathrm{Cr}_{2} \mathrm{O}_{3}$ & 42.66 & 41.18 & 34.33 & 27.70 & 25.02 \\
$\mathrm{FeO}$ & 29.40 & 27.15 & 27.76 & 24.63 & 32.15 \\
$\mathrm{MnO}$ & 0.31 & 0.26 & 0.19 & 0.20 & 0.23 \\
$\mathrm{NiO}$ & 0.12 & 0.11 & 0.10 & 0.18 & 0.29 \\
$\mathrm{MgO}$ & 7.28 & 7.39 & 7.91 & 10.91 & 6.70 \\
$\mathrm{CaO}$ & 0.02 & 0.11 & 0.05 & 0.06 & 0.05 \\
& 97.35 & 97.77 & 97.86 & $\frac{100.06}{96.40}$ &
\end{tabular}

Structural formulae (based on 4 oxygens)

\begin{tabular}{lcllll}
$\mathrm{Si}$ & - & 0.006 & 0.003 & - & 0.005 \\
$\mathrm{Al}$ & 0.673 & 0.805 & 1.013 & 1.255 & 1.174 \\
$\mathrm{Cr}$ & 1.124 & 1.061 & 0.860 & 0.644 & 0.629 \\
$\mathrm{Fe}^{3+}$ & 0.185 & 0.096 & 0.107 & 0.093 & 0.185 \\
$\mathrm{Fe}^{2+}$ & 0.633 & 0.654 & 0.626 & 0.514 & 0.665 \\
$\mathrm{Ti}$ & 0.011 & 0.006 & 0.007 & 0.004 & 0.010 \\
$\mathrm{Mg}$ & 0.361 & 0.358 & 0.374 & 0.479 & 0.317 \\
$\mathrm{Ni}$ & 0.003 & 0.003 & 0.003 & 0.004 & 0.007 \\
$\mathrm{Mn}$ & 0.009 & 0.007 & 0.005 & 0.005 & 0.006 \\
$\mathrm{Ca}$ & 0.001 & 0.004 & 0.002 & 0.002 & 0.002 \\
$\mathrm{Mg} /\left(\mathrm{Mg}+\mathrm{Fe} 2^{+}\right)$ & 0.363 & 0.354 & 0.374 & 0.482 & 0.323 \\
$\mathrm{Chr}$ & 0.568 & 0.540 & 0.434 & 0.323 & 0.316 \\
$\mathrm{Sp}$ & 0.339 & 0.411 & 0.512 & 0.630 & 0.591 \\
$\mathrm{Mt}$ & 0.093 & 0.049 & 0.054 & 0.047 & 0.093 \\
\hline
\end{tabular}

1. Opaque $\mathrm{Cr}$-spinel enclosed in orthopyroxene from ultrabasite 267455, southern Tûgdligtalik (area I).

2. Opaque $\mathrm{Cr}$-spinel enclosed in orthopyroxene from picrite 267435, southern Tûgdligtalik (area I).

3. Opaque $\mathrm{C}_{\mathrm{r}}$-spinel enclosed in phlogopite from picrite 267435 , southern Tûgdligtalik (area I).

4. Transparent intergranular $\mathrm{Cr}$-spinel from picrite 267435 , southern Tûgdligtalik (area I).

5. Opaque $\mathrm{Cr}_{\mathrm{r}}$-spinel enclosed in orthopyroxene from transitional zone between gabbro-norite and picrite 267436 , southern Tûgdligtalik (area I).

$\mathrm{Chr}, \quad \mathrm{Sp}$ and $\mathrm{Mt}$ are defined as $\mathrm{Cr} /\left(\mathrm{Cr}+\mathrm{Al}+\mathrm{Fe}^{3+}\right)$, $\mathrm{Al} /\left(\mathrm{Cr}+\mathrm{Al}+\mathrm{Fe}^{3+}\right)$ and $\mathrm{Fe}^{3+} /\left(\mathrm{Cr}+\mathrm{Al}+\mathrm{Fe}^{3+}\right)$ respectively.

It is uncertain whether igneous trends can be seen through the re-equilibrated overprint of the $\mathrm{Cr}$-spinels. An original trend towards lower $\mathrm{Cr} / \mathrm{Al}$ and lower $\mathrm{Mg} /$ $\left(\mathrm{Mg}+\mathrm{Fe}^{\mathrm{T}}\right)$ may be indicated by opaque $\mathrm{Cr}$-spinels in the picrite sample 267435 and opaque Cr-spinels from the transitional zone (267436) in fig. 23.

\section{Growth of spinel in plagioclase}

Growth of spinel in plagioclase is another early metamorphic effect. Since cloudy plagioclase is invariably confined to the olivine-bearing picritic zone, it is reasonable to assume that the spinel growth causing the plagioclase clouding took place due to chemical reactions between olivine and plagioclase. Since the size of
Table 4. Cloudy plagioclase from metabasite bodies

\begin{tabular}{|c|c|c|c|c|c|c|}
\hline & 1 & 2 & 3 & 4 & 5 & 6 \\
\hline $\mathrm{SiO}_{2}$ & 56.91 & 53.18 & 56.04 & 48.00 & 61.73 & 53.95 \\
\hline $\mathrm{TiO}_{2}$ & 0.19 & 0.02 & 0.04 & 0.00 & 0.02 & 0.03 \\
\hline $\mathbf{A l}_{2} \mathbf{O}_{3}$ & 27.36 & 30.29 & 27.54 & 33.99 & 23.93 & 26.47 \\
\hline $\mathrm{Cr}_{2} \mathrm{O}_{3}$ & 0.00 & 0.01 & 0.01 & 0.02 & 0.00 & 0.01 \\
\hline $\mathrm{FeO}^{\mathrm{T}}$ & 0.67 & 1.30 & 0.48 & 3.94 & 0.03 & 0.79 \\
\hline $\mathrm{MnO}$ & 0.02 & 0.02 & 0.04 & 0.02 & 0.01 & 0.02 \\
\hline $\mathrm{NiO}$ & 0.04 & 0.00 & 0.07 & 0.14 & 0.00 & 0.05 \\
\hline $\mathrm{MgO}$ & 1.17 & 2.21 & 0.64 & 3.35 & 0.00 & 1.27 \\
\hline $\mathrm{CaO}$ & 7.10 & 6.69 & 8.09 & 6.11 & 5.58 & 6.84 \\
\hline $\mathrm{Na}_{2} \mathrm{O}$ & 7.08 & 6.84 & 6.88 & 5.97 & 8.57 & 7.21 \\
\hline \multirow[t]{2}{*}{$\mathrm{K}_{2} \mathrm{O}$} & 0.39 & 0.13 & 0.17 & 0.12 & 0.21 & 0.16 \\
\hline & 100.93 & 100.69 & 100.00 & 101.66 & 100.08 & 96.80 \\
\hline \multicolumn{7}{|c|}{ Percentages of cations } \\
\hline $\mathrm{Si}$ & 50.15 & 46.70 & 49.94 & 41.83 & 54.71 & 49.36 \\
\hline $\mathrm{Ti}$ & 0.13 & 0.01 & 0.03 & 0.00 & 0.01 & 0.02 \\
\hline $\mathrm{Al}^{\mathbf{p} \mid \mathrm{g}}$ & 25.93 & 24.36 & 27.54 & 21.62 & 25.00 & 26.38 \\
\hline$\left.A\right|^{s p}$ & 2.49 & 6.99 & 1.38 & 13.29 & - & 2.16 \\
\hline $\mathrm{Cr}$ & 0.00 & 0.01 & 0.01 & 0.01 & 0.00 & 0.01 \\
\hline $\mathrm{Fe}$ & 0.49 & 0.95 & 0.36 & 2.87 & 0.02 & 0.61 \\
\hline $\mathrm{Mn}$ & 0.02 & 0.02 & 0.03 & 0.01 & 0.01 & 0.01 \\
\hline $\mathrm{Ni}$ & 0.03 & 0.00 & 0.05 & 0.10 & 0.00 & 0.04 \\
\hline $\mathbf{M g}$ & 1.53 & 2.89 & 0.85 & 4.35 & 0.00 & 1.74 \\
\hline $\mathrm{Ca}$ & 6.70 & 6.29 & 7.73 & 5.70 & 5.30 & 6.71 \\
\hline $\mathrm{Na}$ & 12.09 & 11.64 & 11.88 & 10.09 & 14.72 & 12.78 \\
\hline $\mathbf{K}$ & 0.44 & 0.14 & 0.20 & 0.13 & 0.23 & 0.18 \\
\hline An of plag. & 35 & 35 & 39 & 36 & 26 & 34 \\
\hline
\end{tabular}

Structural formulae of spinel inclusions (based on 4 oxygens)

$\begin{array}{lllll}\text { Al } & 1.59 & 1.93 & 1.53 & 1.93\end{array}$

$\begin{array}{llllll}\mathrm{Cr} & - & - & 0.01 & -\end{array}$

$\begin{array}{lllll}\mathrm{Fe}^{3+} & 0.25 & 0.07 & 0.40 & 0.07\end{array}$

$\begin{array}{lllll}\mathrm{Fe}^{2+} & 0.07 & 0.19 & 0.01 & 0.36\end{array}$

$\begin{array}{lllll}\mathrm{Ti} & 0.08 & - & 0.03 & \text { - }\end{array}$

$\begin{array}{lllll}\mathrm{Mg} & 0.98 & 0.80 & 0.94 & 0.63\end{array}$

$\begin{array}{lllll}\mathrm{Ni} & 0.02 & - & 0.05 & 0.01\end{array}$

$\begin{array}{lllll}\mathrm{Mn} & 0.01 & 0.01 & 0.03 & \text {. }\end{array}$

$\mathrm{Mg} /\left(\mathrm{Mg}+\mathrm{Fe}^{2+}\right) \quad 0.93 \quad 0.81 \quad 0.99 \quad 0.64$

Weight percentage of bulk analysis

\begin{tabular}{lllll} 
plg & 95.51 & 89.72 & 97.37 & 79.83 \\
\hline
\end{tabular}

\begin{tabular}{lrrrr} 
sp & 4.49 & 10.28 & 2.63 & 20.17 \\
\hline
\end{tabular}

1. Central part of pale brown plagioclase from picrite 267435, southern Tûgdligtalik (area I).

2. Central part of dark brown plagioclase from picrite 267435, southern Tagdligtalik (area I).

3. Central part of pale brown plagioclase from transitional zone between gabbro-norite and picrite 267436, southern Túgdligtalik (area I).

4. Central part of almost opaque plagioclase from transitional zone between gabbro-norite and picrite 267436, southern Túgdligtalik (area I).

5. Clear rim zone of dark plagioclase from transitional zone between gabbro-norite and picrite 267436, southern Túgdligtalik (area l).

6. Central part of medium to dark brown plagioclase from picrite 267482, southern Tûgdligtalik (area I). 

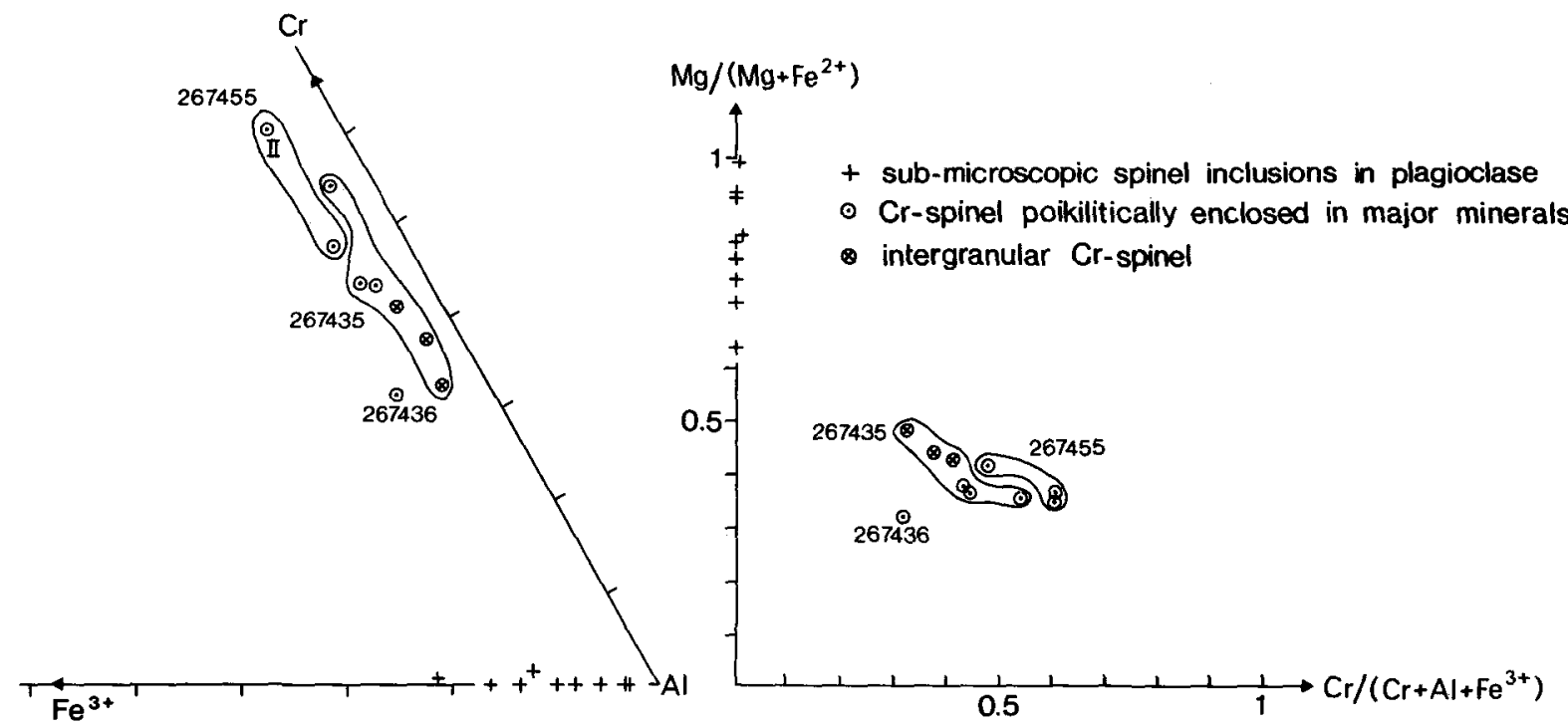

Fig. 23. $\mathrm{Cr}-\mathrm{Al}-\mathrm{Fe}^{3+}$ plot and plot of $\mathrm{Mg} /\left(\mathrm{Mg}+\mathrm{Fe}^{2+}\right)$ versus $\mathrm{Cr} /\left(\mathrm{Cr}+\mathrm{Al}+\mathrm{Fe}^{3+}\right)$ for $\mathrm{Cr}$-spinel and sub-microscopic spinel inclusions in plagioclase.

the spinels is below the resolution of the microprobe, microprobe analyses of cloudy plagioclase (Table 4) only provide the bulk chemistry of a plagioclase-spinel assemblage. Assuming, however, that $\mathrm{Al}$ is the only cation shared by spinel and the host plagioclase, it is possible to calculate the proportions of the two phases. An amount of $\mathrm{Al}$ equal to $\mathrm{K}+\mathrm{Na}+2 \times \mathrm{Ca}$ goes to plagioclase, and the remaining $\mathrm{Al}$ to spinel. In most cases a structural formula for spinel can be obtained from the elements left over from plagioclase (this method, however, does not take into account possible original $\mathrm{Mg}$ and $\mathrm{Fe}$ in plagioclase).

In fig. 23 the calculated spinel inclusions plot outside the field of $\mathrm{Cr}$-spinel analyses. The $\mathrm{Mg} /(\mathrm{Mg}+\mathrm{FeT})$ ratio is higher and the $\mathrm{Cr}$ content negligible. The spinel inclusions have most probably grown due to $\mathrm{Mg}$ and $\mathrm{Fe}$ diffusion from olivine in a reaction like $2 \mathrm{ol}+\mathrm{an}=\mathrm{sp}+$ cpx +2 opx (simplified from Whitney \& McLelland, 1973). The spinel growth depleted the plagioclase in anorthite, and some $\mathrm{Ca}$ and $\mathrm{Si}$ left the plagioclase to participate in pyroxene neoblastesis. Similar development of plagioclase clouding by spinel growth has been described from troctolitic and gabbroic metabasites in the Adirondack Highland (Whitney, 1972; Whitney \& McLelland, 1973; McLelland \& Whitney, 1980).

The pyroxene reaction zone between olivine and plagioclase is only occasionally preserved. In most cases it is replaced by a double corona of fine-grained bladed material, supposed to be Mg-chlorite at the olivine side and a mica at the plagioclase side. The fact that some cloudy plagioclase analyses (e.g. analysis no. 6, Table 4) cannot be resolved into spinel and plagioclase may be due to pyroxene growth within the plagioclase mould.

The clear oligoclase rims on some cloudy plagioclase rims (e.g. analysis no. 5, Table 4) were probably never involved in these reactions. If the sodic rims were an original feature, their lack of $\mathrm{Al}$ may have prevented spinel growth.

\section{Garnet growth}

In the more felsic part of the rock suite garnet growth is the equivalent to spinel growth in picrites. Within about $0.5 \mathrm{~mm}$ from garnet grains plagioclase may be significantly anorthite depleted. In the two sequences of analyses across garnet-plagioclase contacts (Table 5) anorthite contents are lowered by $12 \%$; the plagioclase changes from labradorite to andesine. In 267553 the profile was across neighbouring grains of plagioclase and garnet, whilst in 267555 a corona structure was investigated.

The garnet is usually $60-65 \%$ almandine, the remainder being roughly equal amounts of grossular and pyrope. Some analyses of garnet from the plagioclaseenriched zones (e.g. analysis no. 1, Table 5) show a slight Si deficiency. If this is real (rather than due to analytical uncertainty), it implies a significant andradite component, whilst $\mathrm{Fe}^{3+}$ contents of garnets outside these particular zones are negligible. 
Table 5. Garnet and plagioclase affected by garnet growth in the metabasite bodies

\begin{tabular}{|c|c|c|c|c|c|c|c|c|c|c|c|}
\hline & 1 & 2 & 3 & 4 & 5 & 6 & 7 & 8 & 9 & 10 & 11 \\
\hline $\mathrm{SiO}_{2}$ & 35.65 & 38.56 & 39.09 & 39.19 & 55.92 & 53.07 & 52.71 & 55.40 & 56.29 & 37.69 & 38.44 \\
\hline $\mathrm{TiO}_{2}$ & 0.03 & 0.00 & 0.04 & 0.03 & 0.01 & 0.00 & 0.04 & 0.01 & 0.00 & 0.05 & 0.09 \\
\hline $\mathrm{Al}_{2} \mathrm{O}_{3}$ & 21.16 & 21.09 & 21.27 & 21.22 & 28.00 & 29.80 & 27.88 & 26.84 & 26.42 & 20.62 & 20.60 \\
\hline $\mathrm{Cr}_{2} \mathrm{O}_{3}$ & 0.00 & 0.00 & 0.03 & 0.03 & 0.00 & 0.00 & 0.01 & 0.00 & 0.00 & 0.02 & 0.01 \\
\hline $\mathrm{FeO}^{\mathrm{T}}$ & 28.09 & 29.56 & 28.71 & 29.15 & 0.07 & 0.09 & 0.00 & 0.04 & 0.25 & 28.72 & 27.82 \\
\hline $\mathrm{MnO}$ & 0.82 & 1.26 & 1.13 & 1.15 & 0.00 & 0.01 & 0.00 & 0.00 & 0.02 & 0.98 & 0.75 \\
\hline $\mathrm{NiO}$ & 0.00 & 0.00 & 0.00 & 0.00 & 0.00 & 0.00 & 0.00 & 0.00 & 0.03 & 0.03 & 0.06 \\
\hline $\mathrm{MgO}$ & 5.07 & 3.93 & 4.42 & 4.54 & 0.00 & 0.01 & 0.00 & 0.00 & 0.00 & 3.96 & 4.37 \\
\hline $\mathrm{CaO}$ & 7.90 & 6.77 & 6.90 & 6.97 & 10.06 & 12.42 & 10.90 & 9.55 & 8.69 & 6.61 & 7.29 \\
\hline $\mathrm{Na}_{2} \mathrm{O}$ & 0.00 & 0.03 & 0.01 & 0.00 & 5.72 & 4.43 & 4.91 & 5.88 & 6.42 & 0.01 & 0.05 \\
\hline \multirow[t]{2}{*}{$\mathrm{K}_{2} \mathrm{O}$} & 0.01 & 0.00 & 0.00 & 0.00 & 0.11 & 0.17 & 0.16 & 0.11 & 0.11 & 0.01 & 0.00 \\
\hline & 98.73 & 101.20 & 101.60 & 102.28 & 99.89 & 100.00 & 96.61 & 97.83 & 98.23 & 98.70 & 99.48 \\
\hline An of plag. & & & & & 49 & 61 & 55 & 47 & 43 & & \\
\hline \multicolumn{12}{|c|}{ Structural formulae of garnets (based on 12 oxygens) } \\
\hline $\mathrm{Si}$ & 2.828 & 3.012 & 3.031 & 3.020 & & & & & & 3.017 & 3.040 \\
\hline Al & 1.979 & 1.941 & 1.944 & 1.927 & & & & & & 1.946 & 1.920 \\
\hline $\mathrm{Ti}$ & 0.002 & - & 0.002 & 0.002 & & & & & & 0.003 & 0.006 \\
\hline $\mathrm{Cr}$ & - & - & 0.002 & 0.002 & & & & & & 0.002 & 0.001 \\
\hline $\mathrm{Fe}^{3+}$ & 0.362 & 0.040 & - & 0.027 & & & & & & 0.013 & - \\
\hline $\mathrm{Fe}^{2+}$ & 1.502 & 1.889 & 1.862 & 1.851 & & & & & & 1.909 & 1.839 \\
\hline $\mathrm{Mg}$ & 0.600 & 0.458 & 0.510 & 0.521 & & & & & & 0.473 & 0.515 \\
\hline $\mathrm{Ni}$ & - & - & - & - & & & & & & 0.002 & 0.004 \\
\hline Mn & 0.055 & 0.088 & 0.074 & 0.075 & & & & & & 0.067 & 0.050 \\
\hline $\mathrm{Ca}$ & 0.671 & 0.567 & 0.573 & 0.575 & & & & & & 0.567 & 0.617 \\
\hline $\mathrm{Na}$ & - & 0.005 & 0.002 & - & & & & & & 0.001 & 0.008 \\
\hline $\mathbf{K}$ & 0.001 & - & - & - & & & & & & $\cdot$ & 0.000 \\
\hline Anion deficit & - & - & 0.010 & - & & & & & & - & 0.005 \\
\hline $\mathrm{Mg} /\left(\mathrm{Mg}+\mathrm{Fe}^{\mathrm{T}}\right)$ & 24 & 19 & 22 & 22 & & & & & & 20 & 22 \\
\hline $\begin{array}{l}\text { Distance from } \\
\text { gar/plg contact } \\
(\mathrm{mm})\end{array}$ & & $\begin{array}{c}0.40 \\
\text { (profile) }\end{array}$ & 0.20 & 0.08 & 0.08 & 0.60 & 0.60 & $\begin{array}{c}0.30 \\
\text { (profile) }\end{array}$ & 0.10 & 0.10 & 0.30 \\
\hline
\end{tabular}

1. Central part of single garnet grain from plagioclase-rich sub-zone (sample 267551) within garnet-biotite gabbro in metabasite body on Ikerasak (area II).

2-6. Profile across contact between garnet grain within plagioclase and the host plagioclase from plagioclase-rich sub-zone (sample 267553) in garnet-biotite gabbro from metabasite body on Ikerasak (area II).

7-11. Profile across contact between plagioclase and garnet corona around plagioclase in the central part of the garnet-biotite gabbro zone (sample 267555) of metabasite body on Ikerasak (area II).

\section{Growth of pyroxene oikocrysts}

This is an early metamorphic feature of the ultrabasic/ picritic zone. The fact that cloudy plagioclase may be included in the pyroxene plates shows that the latter are either penecontemporaneous with or postdate the growth of spinel in plagioclase. The platy pyroxenes have in turn re-equilibrated to varying extent. The dusty brown colouring often seen is due to exsolution of oxides, most probably of spinel type. Thus strictly speaking microprobe analyses of dusty pyroxenes in Table 6 are composite, which explains why $\mathrm{Fe}^{3+} / \mathrm{Fe}^{2+}$ are often suspiciously high.

Pyroxene analyses from the ultrabasic/picritic zone show a considerable variation in relative proportions of $\mathrm{Ca}, \mathrm{Mg}$ and $\mathrm{Fe}$ (fig. 24). Submicroscopic exsolution or intergrowth patterns between ortho- and clinopyroxene could explain the apparent variation in wollastonite content of clinopyroxenes from the same sample exhibited by analyses 2 and 3 (Table 6). The $\mathrm{Cr}$ contents of these pyroxenes vary from 1700 to $12000 \mathrm{ppm}$, with no clear preference of clinopyroxene for $\mathrm{Cr}$, and no clear correlation with dustiness. 


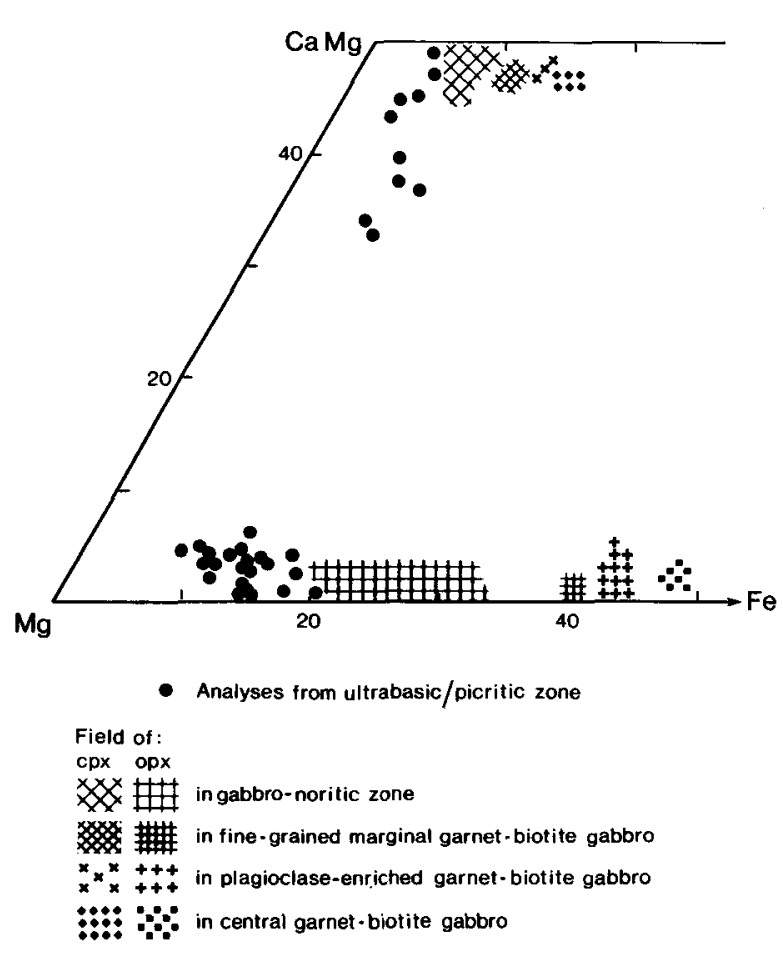

Fig. 24. Ca-Mg-Fe plot of pyroxenes.

\section{Effects on igneous pyroxenes}

As apparent from the broad compositional gap between ortho- and clinopyroxene in the gabbro-norites and garnet-biotite gabbros (fig. 24), the mutual exsolution of ortho- and clinopyroxene is an early metamorphic feature. The Mg-Fe balance between coexisting ortho- and clinopyroxene in these zones also indicates metamorphic rather than igneous temperatures, that is $K_{D}=1.5-2.1$, where

$$
K_{D}=\left(X_{\mathrm{Fe}} / X_{\mathrm{Mg}}\right)_{\mathrm{opx}} /\left(X_{\mathrm{Fe}} / X_{\mathrm{Mg}}\right)_{\mathrm{cpx}}
$$

as compared to values $<1.4$ for typical igneous crystals (Huebner, 1980). The trends from Mg-rich prismatic crystals in the gabbro-norites to Fe-rich interstitial grains in certain garnet-biotite gabbros reflect an igneous trend, however overprinted by metamorphic reequilibration. There is no evidence for the former existence of pigeonite.

$\mathrm{Cr}$ contents of pyroxenes from gabbro-norite and garnet-biotite gabbro may vary by more than an order of magnitude within one rock sample, with no clear preference for clinopyroxene to orthopyroxene.

\section{Amphiboles}

Development of the fine-grained double coronae of bladed material between olivine and plagioclase grains marks the income of wet metamorphic mineral assemblages. It is superseded by the breakdown of the large pyroxene oikocrysts. At this stage metamorphic mineral assemblages with amphiboles as the major mafic mineral phase are developed throughout the rock suite. Exsolution of oblong magnetite veins from mafic igneous minerals possibly took place more than once, but it is particularly important in connection with the breakdown of pyroxene to amphibole (where $(\mathrm{Ca}+\mathrm{Mg}+$ $\mathrm{Fe}) / \mathrm{Si}$ changes from unity to $7 / 8$ ).

Representative microprobe analyses of amphiboles are shown in Table 7. All cummingtonites and certain actinolites show anion deficiencies in the order of magnitude of 0.1 formula unit, even with all $\mathrm{Fe}$ as $\mathrm{Fe}^{2+}$. Since cummingtonites are not likely to be oxy-varieties, the apparent anion deficiency is either attributed to vacancies in the crystal structure or to analytical uncertainty.

Minute weakly pleochroic yellowish, brownish or greenish amphibole grains that fill out interstices in gabbro-norites and garnet-biotite gabbros together with biotite, quartz and accessory minerals may be either igneous or early manifestations of the amphibolite facies metamorphism. They range in composition from magnesio-hornblende through edenitic hornblende to ferroan pargasitic hornblende. In one gabbro-norite sample (267481 from southern Tûgdligtalik) these amphiboles showed pargasitic compositions (analysis no. 3, Table 7). Apart from the $\mathrm{Mg} /\left(\mathrm{Mg}+\mathrm{Fe}^{\mathrm{T}}\right)$ ratio that tends to parallel the pyroxene trends, the composition of these fine-grained amphiboles is only weakly correlated with bulk rock composition.

Amphiboles of similar grain size, colour and composition can in some cases be seen to have grown at the expense of pyroxenes (fig. 25), which seems to favour the interpretation that all amphiboles are metamorphic. The large compositional variation of these amphiboles (even within one sample) reflects that element migration in the initial stages of recrystallisation only occurred on a very local scale, so that equilibrium was only achieved with the local chemical environment. The initial breakdown of pyroxene often gives place to actinolite in the central part of the former pyroxene grain with a corona of alkali-rich aluminous minute amphibole grains. In these cases the availability of $\mathrm{Al}$ from surrounding plagioclase has been the controlling factor.

Breakdown of igneous minerals may be complete giving rise to amphibolites, hornblendites and similar rock 
Table 6. Pyroxene from the metabasite bodies

\begin{tabular}{|c|c|c|c|c|c|c|c|}
\hline & 1 & 2 & 3 & 4 & 5 & 6 & 7 \\
\hline $\mathrm{SiO}_{2}$ & 52.51 & 53.52 & 52.17 & 53.24 & 52.50 & 52.64 & 52.11 \\
\hline $\mathrm{TiO}_{2}$ & 0.05 & 0.28 & 0.31 & 0.01 & 0.23 & 0.12 & 0.23 \\
\hline $\mathrm{Al}_{2} \mathrm{O}_{3}$ & 1.56 & 3.82 & 4.82 & 1.58 & 2.55 & 1.16 & 1.75 \\
\hline $\mathrm{Cr}_{2} \mathrm{O}_{3}$ & 0.86 & 0.70 & 1.08 & 0.26 & 0.31 & 0.08 & 0.03 \\
\hline $\mathrm{FeO}^{\mathrm{T}}$ & 8.47 & 4.60 & 3.43 & 16.95 & 4.96 & 10.21 & 8.48 \\
\hline $\mathrm{MnO}$ & 0.17 & 0.14 & 0.06 & 0.41 & 0.09 & 0.10 & 0.19 \\
\hline $\mathrm{NiO}$ & 0.18 & 0.01 & 0.12 & 0.06 & 0.04 & 0.13 & 0.02 \\
\hline $\mathrm{MgO}$ & 31.45 & 20.04 & 15.83 & 28.01 & 15.17 & 13.20 & 13.99 \\
\hline $\mathrm{CaO}$ & 3.31 & 16.50 & 20.70 & 0.32 & 23.34 & 23.35 & 22.70 \\
\hline $\mathrm{Na}_{2} \mathrm{O}$ & 0.10 & 1.07 & 1.61 & 0.00 & 0.41 & 0.15 & 0.23 \\
\hline \multirow[t]{2}{*}{$\mathrm{K}_{2} \mathrm{O}$} & 0.01 & 0.00 & 0.04 & 0.00 & 0.40 & 0.00 & 0.02 \\
\hline & 98.67 & 100.68 & 100.17 & 100.84 & 100.00 & 101.14 & 99.75 \\
\hline \multicolumn{8}{|c|}{ Structural formulae (based on 6 oxygens) } \\
\hline $\mathrm{Si}$ & 1.857 & 1.904 & 1.882 & 1.902 & 1.925 & 1.952 & 1.943 \\
\hline $\mathrm{Al}^{\mathrm{IV}}$ & 0.065 & 0.096 & 0.118 & 0.066 & 0.075 & 0.048 & 0.057 \\
\hline $\mathbf{A l}^{\mathrm{VI}}$ & - & 0.064 & 0.087 & - & 0.035 & 0.003 & 0.020 \\
\hline $\mathrm{Ti}$ & 0.001 & 0.008 & 0.008 & - & 0.006 & 0.003 & 0.006 \\
\hline $\mathrm{Cr}$ & 0.024 & 0.020 & 0.031 & 0.007 & 0.009 & 0.002 & 0.001 \\
\hline $\mathrm{Fe}^{3+}$ & 0.202 & 0.070 & 0.099 & 0.123 & 0.067 & 0.048 & 0.044 \\
\hline $\mathrm{Fe}^{2+}$ & 0.049 & 0.068 & 0.004 & 0.385 & 0.083 & 0.270 & 0.218 \\
\hline $\mathbf{M g}$ & 1.659 & 1.063 & 0.851 & 1.491 & 0.831 & 0.728 & 0.777 \\
\hline $\mathrm{Ni}$ & 0.005 & - & 0.003 & 0.002 & 0.001 & 0.004 & 0.001 \\
\hline Mn & 0.005 & 0.004 & 0.002 & 0.012 & 0.003 & 0.003 & 0.006 \\
\hline $\mathrm{Ca}$ & 0.126 & 0.629 & 0.800 & 0.012 & 0.917 & 0.928 & 0.907 \\
\hline $\mathrm{Na}$ & 0.007 & 0.074 & 0.113 & - & 0.029 & 0.011 & 0.016 \\
\hline $\mathbf{K}$ & - & - & 0.002 & - & 0.019 & - & 0.004 \\
\hline $\mathrm{Mg} /\left(\mathrm{Mg}+\mathrm{Fe}^{\mathrm{T}}\right)$ & 87 & 89 & 89 & 75 & 85 & 67 & 75 \\
\hline $\mathrm{Mg} /\left(\mathbf{M g}+\mathrm{Fe}^{2+}\right)$ & 97 & 94 & 100 & 79 & 91 & 73 & 78 \\
\hline Wo & 6.9 & 35.7 & 48.3 & 0.6 & 50.1 & 48.2 & 47.7 \\
\hline En & 90.5 & 60.4 & 51.4 & 79.0 & 45.4 & 37.8 & 40.9 \\
\hline Fs & 2.6 & 3.9 & 0.3 & 20.4 & 4.5 & 14.0 & 11.4 \\
\hline
\end{tabular}

1. Dusty brown orthopyroxene plate from ultrabasite 267455 , southern Tûgdligtalik (area I).

2. Dusty clinopyroxene domain in platy orthopyroxene from picrite 267435 , southern Tûgdligtalik (area I).

3. Dusty clinopyroxene domain in platy orthopyroxene from picrite 267435 , southern Tûgdligtalik (area I).

4. Prismatic orthopyroxene from gabbro-norite 267442 , southern Tûgdligtalik (area I).

5. Prismatic clinopyroxene from gabbro-norite 267442 , southern Tûgdligtalik (area I).

6. Interstitial clinopyroxene from plagioclase-rich garnet-biotite gabbro 267553 , Ikerasak (area II).

7. Prismatic clinopyroxene from fine-grained garnet-biotite gabbroic border zone 267565 of metabasite body on Ikerasak (area II).

types. In former ultrabasites, picrites and gabbro-norites magnesio-hornblendes dominate, often accompanied by cummingtonite in the more mafic varieties. The magnesio-hornblende is in general strongly pleochroic, varying from pale brown-green to deep green. In the fold-shaped metabasite body on Qíngup qáqâ (fig. 9) magnesio-hornblende and cummingtonite show mutual exsolution in lamellae and domain-like patterns (fig. 26).

The recrystallised equivalents of less mafic gabbronorites and garnet-biotite gabbros are devoid of cummingtonite, and the hornblende is usually a more alkali- 
Table 7. Amphibole from the metabasite bodies (classified according to Leake (1978))

\begin{tabular}{lrrrrrrrr}
\hline & 1 & \multicolumn{1}{c}{2} & 3 & \multicolumn{1}{c}{4} & 5 & 6 & 7 & 8 \\
\hline $\mathrm{SiO}_{2}$ & 56.87 & 49.10 & 41.10 & 49.12 & 42.63 & 52.74 & 41.97 & 42.66 \\
$\mathrm{TiO}_{2}$ & 0.10 & 0.76 & 2.68 & 0.31 & 1.27 & 0.22 & 1.67 & 1.31 \\
$\mathrm{Al}_{2} \mathrm{O}_{3}$ & 0.96 & 10.13 & 12.34 & 9.56 & 10.80 & 2.11 & 11.86 & 11.63 \\
$\mathrm{Cr}_{2} \mathrm{O}_{3}$ & 0.00 & 0.27 & 0.69 & 1.11 & 0.03 & 0.00 & 0.16 & 0.09 \\
$\mathrm{FeO}^{\mathrm{T}}$ & 15.51 & 8.84 & 8.69 & 7.12 & 14.73 & 14.79 & 15.35 & 15.60 \\
$\mathrm{MnO}$ & 0.38 & 0.12 & 0.14 & 0.15 & 0.23 & 0.21 & 0.10 & 0.03 \\
$\mathrm{NiO}$ & 0.02 & 0.10 & 0.10 & 0.10 & 0.03 & 0.00 & 0.00 & 0.11 \\
$\mathrm{MgO}$ & 23.17 & 16.26 & 14.10 & 18.00 & 11.22 & 14.46 & 11.06 & 9.68 \\
$\mathrm{CaO}$ & 0.83 & 11.25 & 11.94 & 12.10 & 11.88 & 11.14 & 11.78 & 10.96 \\
$\mathrm{Na}$ & 0.09 & 1.31 & 2.08 & 1.42 & 1.25 & 0.26 & 1.43 & 1.35 \\
$\mathrm{~K}_{2} \mathrm{O}$ & 0.00 & 0.15 & 1.27 & 0.30 & 1.30 & 0.06 & 1.87 & 0.91 \\
& 97.93 & 98.29 & 95.13 & 99.29 & 95.37 & 95.99 & 97.25 & 94.33
\end{tabular}

Structural formulae. For amphiboles containing sufficient amounts of $\mathrm{Ca}$ and $\mathrm{Na}$ to fill out the M4 site, $\mathrm{Fe}^{3+} / \mathrm{Fe}^{2+}$ has been calculated on the assumption that $\mathrm{Si}+\mathrm{Al}+\mathrm{Ti}+\mathrm{Cr}+\mathrm{Fe}+\mathrm{Mg}+\mathrm{Ni}+\mathrm{Mn}$ equals 13 When $\mathrm{Mg}$ and/or $\mathrm{Fe}$ is needed at the $\mathrm{M} 4$ site, $\mathrm{Fe}^{3+} / \mathrm{Fe}^{2+}$ has been calculated on the assumption that all elements except $\mathrm{K}$ (which is assigned to the $A$ site) together equal 15 . In both cases 23 oxides assumed.

\begin{tabular}{lcccccccc}
$\mathrm{Si}$ & 7.97 & 6.81 & 6.17 & 6.75 & 6.47 & 7.76 & 6.28 & 6.50 \\
$\mathrm{Al}^{\mathrm{IV}}$ & 0.03 & 1.19 & 1.83 & 1.25 & 1.53 & 0.24 & 1.72 & 1.50 \\
$\mathrm{Al}^{\mathrm{VI}}$ & 0.13 & 0.47 & 0.35 & 0.31 & 0.41 & 0.12 & 0.38 & 0.57 \\
$\mathrm{Ti}$ & 0.01 & 0.08 & 0.30 & 0.03 & 0.15 & 0.02 & 0.19 & 0.15 \\
$\mathrm{Cr}$ & - & 0.03 & 0.08 & 0.12 & - & - & 0.02 & 0.10 \\
$\mathrm{Fe}^{3+}$ & - & 0.77 & 0.12 & 0.73 & 0.28 & 0.10 & 0.34 & 0.09 \\
$\mathrm{Fe}^{2+}$ & 1.82 & 0.26 & 0.97 & 0.09 & 1.59 & 1.72 & 1.59 & 1.89 \\
$\mathrm{Mg}$ & 4.84 & 3.37 & 3.15 & 3.69 & 2.54 & 3.18 & 2.47 & 2.19 \\
$\mathrm{Ni}$ & - & 0.01 & 0.01 & 0.01 & - & - & - & 0.01 \\
$\mathrm{Mn}$ & 0.05 & 0.01 & 0.02 & 0.02 & 0.03 & 0.03 & 0.01 & - \\
$\mathrm{Ca}$ & 0.12 & 1.67 & 1.92 & 1.78 & 1.94 & 1.76 & 1.89 & 1.80 \\
$\mathrm{Na}$ & 0.03 & 0.35 & 0.60 & 0.38 & 0.37 & 0.07 & 0.42 & 0.40 \\
$\mathrm{~K}$ & - & 0.03 & 0.24 & 0.05 & 0.25 & 0.01 & 0.36 & 0.18 \\
$\mathrm{Anion}$ deficit & 0.09 & - & - & - & - & - & - & - \\
$\mathrm{Mg} /\left(\mathrm{Mg}+\mathrm{Fe}^{\mathrm{T}}\right.$ ) & 73 & 77 & 74 & 82 & 58 & 64 & 56 & 52 \\
\hline
\end{tabular}

1. Colourless cummingtonite from fold-shaped recrystallised gabbro-noritic metabasite body 267426 on Qíngup qáqâ (area I).

2. Pale to deep green magnesio-hornblende lamella in cummingtonite (1).

3. Minute yellow-green pargasite grain from gabbro-norite 267481 , southern Tûgdligtalik (area I).

4. Minute greyish green magnesio-hornblende from hornblendite $\mathbf{2 6 7 4 3 8}$ border zone of metabasite body on southern Tûgdligtalik (area I).

5. Pale greenish brown to deep green strongly pleochroic ferroan pargasitic hornblende from amphibolitic border zone $\mathbf{2 6 7 4 7 4}$ of metabasite body on southern Tûgdligtalik (area I).

6. Actinolite replacing pyroxene in garnet-biotite gabbro 267551 on Ikerasak (area II).

7. Minute pale greyish green ferroan pargasitic hornblende grain from garnet-biotite gabbro 267551 on Ikerasak (area II).

8. Minute pale yellowish green edenitic hornblende from fine-grained garnet-biotite gabbroic border zone $\mathbf{2 6 7 5 6 5}$ of metabasite body on Ikerasak (area II).

rich type. In the originally uppermost part of the large metabasite body on southern Tûgdligtalik the amphibole is a ferroan pargasitic hornblende. It is strongly pleochroic, varying from pale greenish-brown to deep green.
Fig. 27 shows the distribution of amphiboles in the $\mathrm{Ca}-\mathrm{Mg}-\mathrm{Fe}$ triangle together with patterns of $\mathrm{Si}-\mathrm{Al}$ substitution and alkali contents in calcic amphiboles. 


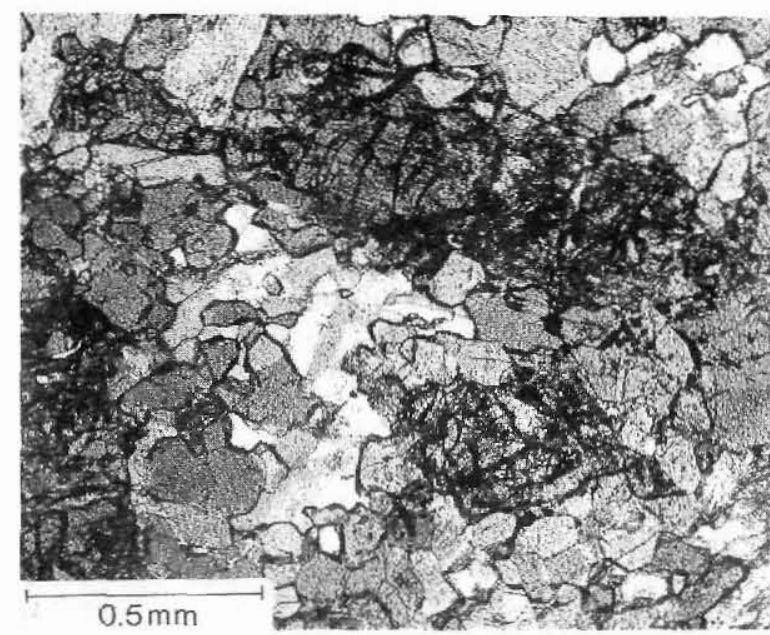

Fig. 25. Fine-grained amphibole (the medium-dark mineral) growing at the expense of pyroxene (the partly disintegrated dark high-relief mineral upper right) in marginal gabbro-norite zone of a metabasite body on Ikerasak. The bright low-relief mineral is metamorphic plagioclase (plane polarised light).

\section{Micas}

There seem to be at least two generations of micas. It might be argued that interstitial biotite and biotite forming stellate aggregates (both intimately associated with aggregates of ilmenite and rutile) crystallised from an interstitial melt between cumulus pyroxene, plagioclase or olivine. In any case this early biotite predates the breakdown of pyroxene to amphibole.

Some mica is, however, clearly metamorphic. Biotite laths may for example intersect amphibole grains in

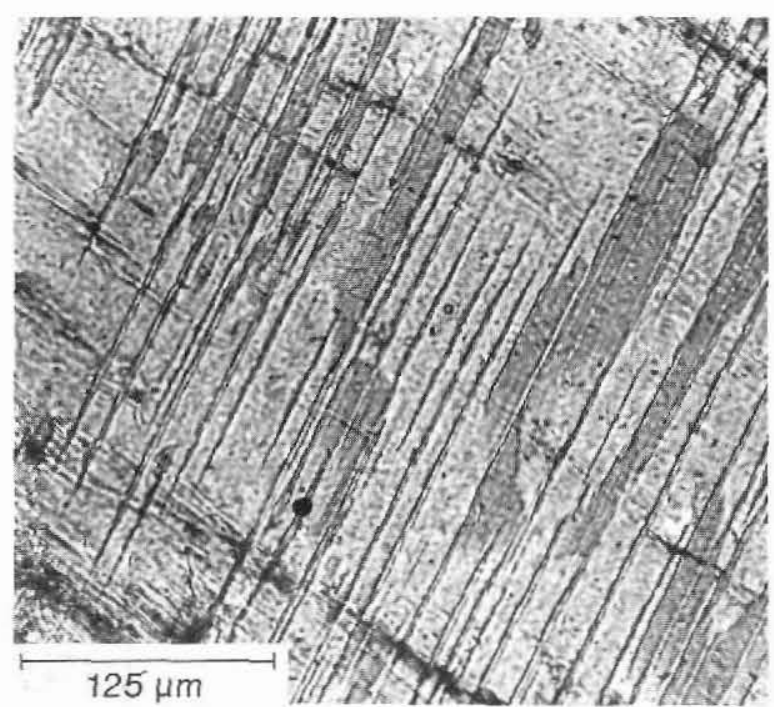

Fig. 26. Exsolution lamellae of magnesio-hornblende in cummingtonite from the fold-shaped metabasite body on western Qingup qáqâ, area 1 (plane polarised light).

rocks that are devoid of pyroxene (and thus strongly recrystallised). This phenomenon is mostly restricted to border zones of metabasite bodies and to metabasite bodies within shear zones. The late biotite is in general not associated with aggregates of rutile and ilmenite, but may show exsolution of oblong magnetite parallel to long edges or at borders to amphiboles. The chemistry of samples with high amounts of late biotite often indicate alkali metasomatism from outside. Minute zircons with radiation haloes have in one case been found

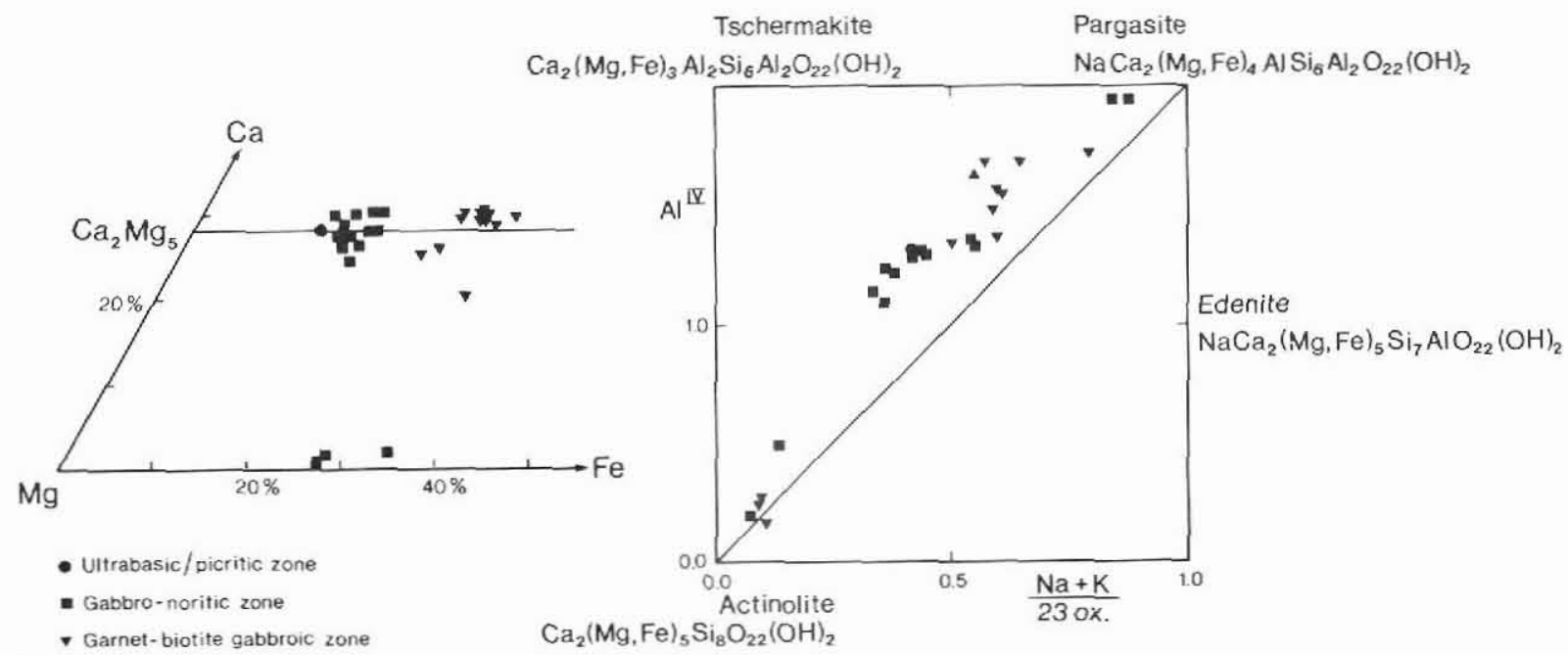

Fig. 27. $\mathrm{Ca}-\mathrm{Mg}-\mathrm{Fe}$ plot of amphiboles together with plot of tetrahedral $\mathrm{Al}$ versus alkali contents for calcic amphiboles from various rock types in metabasite bodies. 
Table 8. Mica from the metabasite bodies

\begin{tabular}{lrrr}
\hline & \multicolumn{1}{c}{1} & \multicolumn{1}{c}{2} & \multicolumn{1}{c}{3} \\
\hline $\mathrm{SiO}_{2}$ & 38.71 & 38.22 & 36.03 \\
$\mathrm{TiO}_{2}$ & 5.68 & 4.73 & 5.23 \\
$\mathrm{Al}_{2} \mathrm{O}_{3}$ & 15.30 & 14.55 & 14.60 \\
$\mathrm{Cr}_{2} \mathrm{O}_{3}$ & 1.22 & 0.41 & 0.07 \\
$\mathrm{FeO}^{\mathrm{T}}$ & 3.92 & 11.34 & 16.70 \\
$\mathrm{MnO}$ & 0.07 & 0.12 & 0.12 \\
$\mathrm{NiO}$ & 0.19 & 0.10 & 0.06 \\
$\mathrm{MgO}$ & 21.66 & 17.03 & 11.59 \\
$\mathrm{CaO}$ & 0.00 & 0.02 & 0.03 \\
$\mathrm{Na}$ & 0.54 & 0.15 & 0.13 \\
$\mathrm{~K}_{2} \mathrm{O}$ & 9.21 & 9.10 & 9.10 \\
& 96.50 & 95.77 & 93.66 \\
$\mathrm{Mg} /\left(\mathrm{Mg}+\mathrm{Fe}^{\mathrm{T}}\right)$ & 91 & 73 & 55 \\
\hline
\end{tabular}

1. Phlogopite (supposed to be the earliest generation) from picrite 267435 , southern Tûgdligtalik (area I).

2. Biotite (earliest generation) from gabbro-norite 267442 , southern Tûgdligtalik (area I).

3. Biotite forming part of stellate aggregate in garnet-biotite gabbro 267565 , northern fine-grained contact zone of metabasite body on Ikerasak (area II).

enclosed in late biotite in an alkali metasomatised rock sample.

Although textural evidence is compatible with the existence of early igneous biotite, chemical analyses do not provide any such evidence. Biotite analyses in Table 8 show a high $\mathrm{Cr}$ content, and $\mathrm{Mg} /\left(\mathrm{Mg}+\mathrm{Fe}^{\mathrm{T}}\right)$ ratios are not very fractionated relative to pyroxenes from the same sample (fig. 28). If interstitial biotites and stellate biotite aggregates are igneous, they have re-equilibrated with pyroxenes.

\section{Other effects of the amphibolite facies metamorphism}

Plagioclase is usually the last igneous mineral that breaks down. Recrystallised plagioclase in amphibolites and their cummingtonite-bearing associates is andesine.

Centimetre-thick deformation zones of hornblendite have developed in folded parts of metabasite bodies on Ikerasak, and sphene and garnet growth took place in rocks of certain bulk compositions during amphibolite facies metamorphism (not to be confused with the corona garnet of dry metamorphism). Moreover one centimetre large grains of garnet occur in the gabbro-noritic zone of the large metabasite body on southern Tûgdligtalik, at the contact to an intersecting pegmatite. The garnet is here restricted to subhorizontal planes which have acted as channels for metasomatising fluids.

\section{Greenschist facies metamorphism}

The growth of chlorite, epidote and sericite at the expense of biotite and feldspar together with development of serpentinised cracks in olivine are all manifestations of a later retrogressive greenschist facies metamorphism. Similar retrogression is found in the main gneiss where it can be seen to be closely related to the development of major fracture zones in the area.

\section{Bulk rock chemistry}

\section{General}

Representative chemical analyses of metabasite rock types are given in Table 9, together with estimated bulk compositions of the large metabasite intrusion on south-

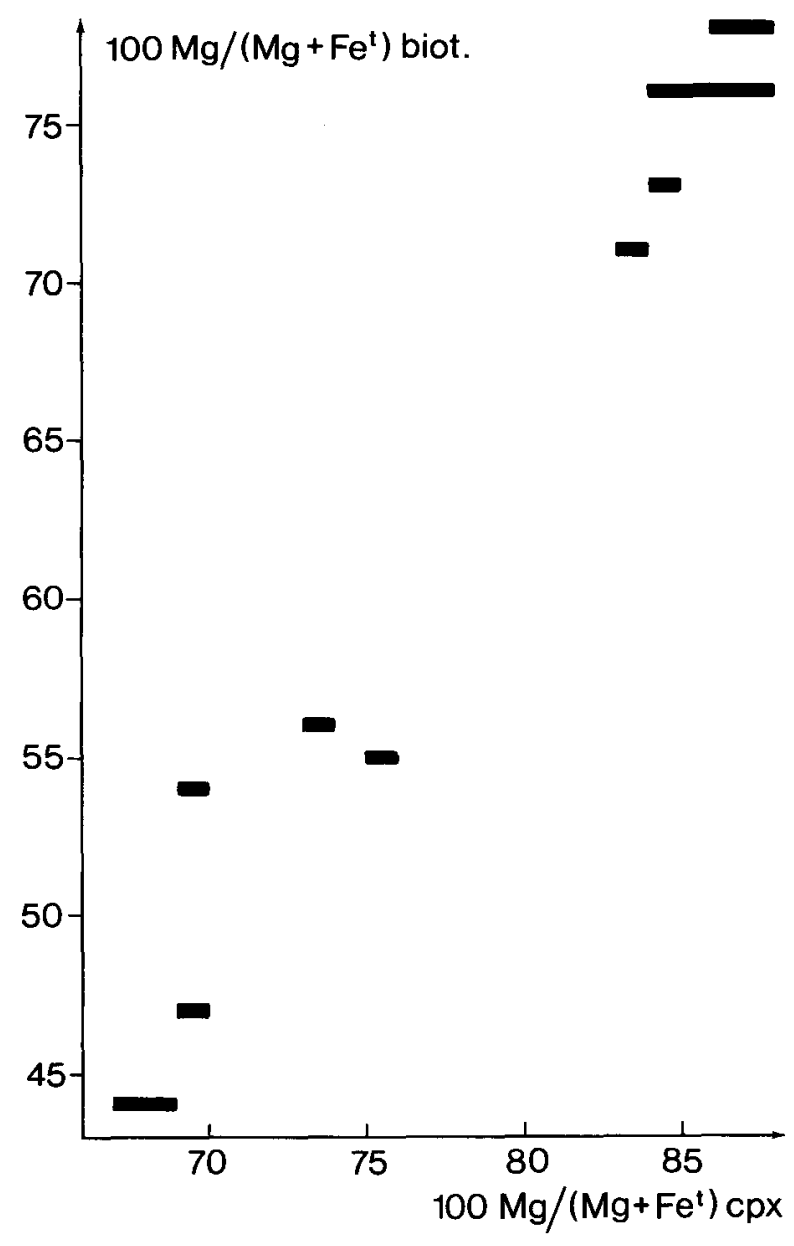

Fig. 28. Correlation between $\mathrm{Mg} /\left(\mathrm{Mg}+\mathrm{Fe}^{\mathrm{T}}\right)$ ratios of biotite and clinopyroxene in metabasite bodies. 
Table 9. Representative whole rock analyses

\begin{tabular}{|c|c|c|c|c|c|c|c|c|c|c|c|c|}
\hline GGU No. & 249078 & 267472 & 267436 & 267471 & 267550 & 267552 & 267556 & 267566 & 267557 & 267498 & X.1 & $\mathrm{X.2}$ \\
\hline \multicolumn{13}{|l|}{ wt $\%$} \\
\hline $\mathrm{SiO}_{2}$ & 41.99 & 45.42 & 50.67 & 53.36 & 52.71 & 52.18 & 52.34 & 52.05 & 51.81 & 51.75 & 52.34 & 51.96 \\
\hline $\mathrm{TiO}_{2}$ & 0.27 & 0.31 & 0.40 & 0.43 & 0.49 & 0.64 & 0.86 & 0.67 & 1.11 & 0.63 & 0.40 & 0.69 \\
\hline $\mathrm{Al}_{2} \mathrm{O}_{3}$ & 6.24 & 6.53 & 8.32 & 9.82 & 10.58 & 16.56 & 14.23 & 14.12 & 14.19 & 13.75 & 9.26 & 13.91 \\
\hline $\mathrm{Fe}_{2} \mathrm{O}_{3}$ & 4.79 & 2.47 & 5.09 & 1.72 & 1.81 & 1.94 & 2.90 & 1.63 & 3.67 & 1.82 & 1.97 & 2.15 \\
\hline $\mathrm{FeO}$ & 7.10 & 7.57 & 4.85 & 7.52 & 7.97 & 7.74 & 9.20 & 8.29 & 9.89 & 7.64 & 7.45 & 8.47 \\
\hline $\mathrm{MnO}$ & 0.18 & 0.15 & 0.16 & 0.16 & 0.17 & 0.15 & 0.19 & 0.16 & 0.19 & 0.16 & 0.16 & 0.17 \\
\hline $\mathrm{MgO}$ & 29.53 & 29.17 & 22.55 & 16.38 & 14.97 & 6.56 & 6.43 & 8.44 & 4.72 & 9.20 & 18.49 & .66 \\
\hline $\mathrm{CaO}$ & 2.57 & 4.57 & 5.86 & 6.78 & 8.00 & 10.71 & 10.13 & 10.76 & 9.32 & 10.89 & 6.60 & 9.67 \\
\hline $\mathrm{Na}_{2} \mathrm{O}$ & 0.38 & 0.70 & 0.97 & 1.38 & 1.26 & 2.22 & 2.21 & 1.94 & 2.24 & 2.28 & 1.23 & 1.99 \\
\hline $\mathrm{K}_{2} \mathrm{O}$ & 0.07 & 0.23 & 0.37 & 0.56 & 0.31 & 0.49 & 0.62 & 0.48 & 0.87 & 0.43 & 0.45 & 0.50 \\
\hline $\mathrm{H}_{2} \mathrm{O}$ & 2.42 & 1.50 & 0.51 & 1.26 & 0.87 & 0.73 & 0.77 & 1.35 & 1.72 & 1.34 & 1.09 & 0.86 \\
\hline \multirow[t]{2}{*}{$\mathrm{P}_{2} \mathrm{O}_{5}$} & 0.06 & 0.05 & 0.06 & 0.06 & 0.06 & 0.09 & 0.12 & 0.09 & 0.17 & 0.08 & 0.06 & 0.09 \\
\hline & 95.60 & 98.67 & 99.81 & 99.43 & 99.20 & 100.01 & 100.00 & 99.98 & 99.90 & 99.97 & 99.50 & 99.12 \\
\hline $\mathrm{Fe}_{2} \mathrm{O}_{3} / \mathrm{FeO}$ & 0.67 & 0.33 & 1.05 & 0.23 & 0.23 & 0.25 & 0.32 & 0.20 & 0.37 & 0.24 & & \\
\hline $100 \mathrm{Mg} /\left(\mathrm{Mg}+\mathrm{Fe}^{\mathrm{T}}\right)$ & 82.0 & 84.1 & 80.6 & 76.3 & 73.5 & 55.2 & 49.2 & 60.6 & 38.9 & 63.2 & 78.1 & 59.7 \\
\hline $\begin{array}{l}\mathrm{CaO} / \mathrm{Al}_{2} \mathrm{O}_{3} \\
p p m\end{array}$ & 0.41 & 0.70 & 0.70 & 0.69 & 0.76 & 0.65 & 0.71 & 0.76 & 0.66 & 0.79 & 0.71 & 0.70 \\
\hline Sc & 18.8 & 17.6 & 24.0 & 29.3 & 36.5 & 30.9 & 37.2 & 37.1 & 37.8 & 41.1 & 27.7 & 34.3 \\
\hline $\mathrm{V}$ & 128 & 122 & 151 & 169 & 217 & 196 & 256 & 228 & 253 & 240 & 163 & 223 \\
\hline $\mathrm{Cr}$ & 20000 & 9370 & 3720 & 2110 & 1770 & 129 & 20 & 490 & 7 & 676 & 3170 & 498 \\
\hline $\mathbf{N i}$ & 1550 & 1500 & 776 & 335 & 312 & 124 & 113 & 162 & 79 & 184 & 551 & 168 \\
\hline $\mathbf{R b}$ & $<1$ & 4.8 & 9.1 & 13.2 & 6.7 & 10.4 & 16.3 & 10.4 & 22.4 & 8.8 & 12.7 & 11.9 \\
\hline $\mathrm{Sr}$ & 50 & 81 & 116 & 125 & 123 & 207 & 192 & 173 & 257 & 184 & 116 & 178 \\
\hline$Y$ & 3.6 & 5.9 & 8.6 & 10.7 & 10.8 & 14.5 & 19.3 & 16.3 & 26.2 & 16.9 & 9.3 & 15.5 \\
\hline $\mathrm{Zr}$ & 30.6 & 37.8 & 53.2 & 57.9 & 59.4 & 84.3 & 106 & 77.6 & 133 & 60.6 & 55.2 & 87.1 \\
\hline $\mathrm{Nb}$ & 0.7 & 1.4 & $<0.5$ & 1.7 & 2.0 & 2.1 & 3.3 & 2.9 & n.d. & n.d. & 1.8 & 2.8 \\
\hline La & n.d. & 4.0 & 6.8 & 9.4 & 5.4 & 10.6 & 12.4 & 8.9 & 21.7 & 8.2 & 7.9 & 9.7 \\
\hline $\mathrm{Ce}$ & n.d. & n.d. & 15.1 & 14.9 & 11.8 & 19.6 & 26.5 & 20.5 & 38.0 & 15.9 & & \\
\hline $\mathrm{Nd}$ & n.d. & n.d. & 9.3 & 9.3 & 8.5 & 12.3 & 17.3 & 13.4 & 24.5 & 11.7 & & \\
\hline
\end{tabular}

249078. Ultrabasite, south-western Qíngup qáqâ (area I).

267472. Picrite, large metabasite body on southern Tûgdligtalik (area I).

267436. Transitional zone between picrite and gabbro-norite, large metabasite body on southern Tûgdligtalik (area I).

267471. Gabbro-norite, large metabasite body on southern Tûgdligtalik (area I).

267550. Gabbro-norite, central metabasite body on Ikerasak (area II).

267552. Plagioclase-rich garnet-biotite gabbro, central metabasite body on Ikerasak (area II).

267556. Central garnet-biotite gabbro, central metabasite body on Ikerasak (area II).

267566. Marginal clinopyroxene-rich garnet-biotite gabbro, central metabasite body on Ikerasak (area II).

267557. Central garnet-biotite gabbro, recrystallized in amphibolite facies, central metabasite body on Ikerasak (area II).

267498. Central part of pinch-and-swell metabasite body, recrystallized in amphibolite facies, Qôroq qiterdleq (area I).

X.1 Estimated bulk composition of large metabasite body on southern Tûgdligtalik (area I).

X.2 Estimated bulk composition of central metabasite body on Ikerasak (area II).

n.d. not determined

ern Tûgdligtalik and the $200 \mathrm{~m}$ thick intrusion on Ikerasak.

The ultrabasites and picrites are generally distinguished from the gabbro-norites and the garnet-biotite gabbros by their distinctly lower $\mathrm{SiO}_{2}$ contents and higher $\mathrm{Mg} /\left(\mathrm{Mg}+\mathrm{Fe}^{\mathrm{T}}\right) . \mathrm{SiO}_{2}$ mostly varies from 42 to $49 \%$, higher for picrites than for ultrabasites. $\mathrm{Mg} /(\mathrm{Mg}$ $+\mathrm{Fe}^{\mathrm{T}}$ ) typically varies from 81 to $87 \%$. High $\mathrm{MgO}$
(23-36\%), Ni (900-1700 ppm) and in particular $\mathrm{Cr}$ $\left(4000-20000 \mathrm{ppm}\left(\approx 3 \% \mathrm{Cr}_{2} \mathrm{O}_{3}\right)\right)$ contents are characteristic of ultrabasites and picrites. The chemistry of picrite sample 267436 which was taken within the $10 \mathrm{~cm}$ wide transitional zone of the large metabasite body on southern Tûgdligtalik is intermediate between typical picrites and gabbro-norites.

$\mathrm{SiO}_{2}$ contents of the gabbro-norites typically range 

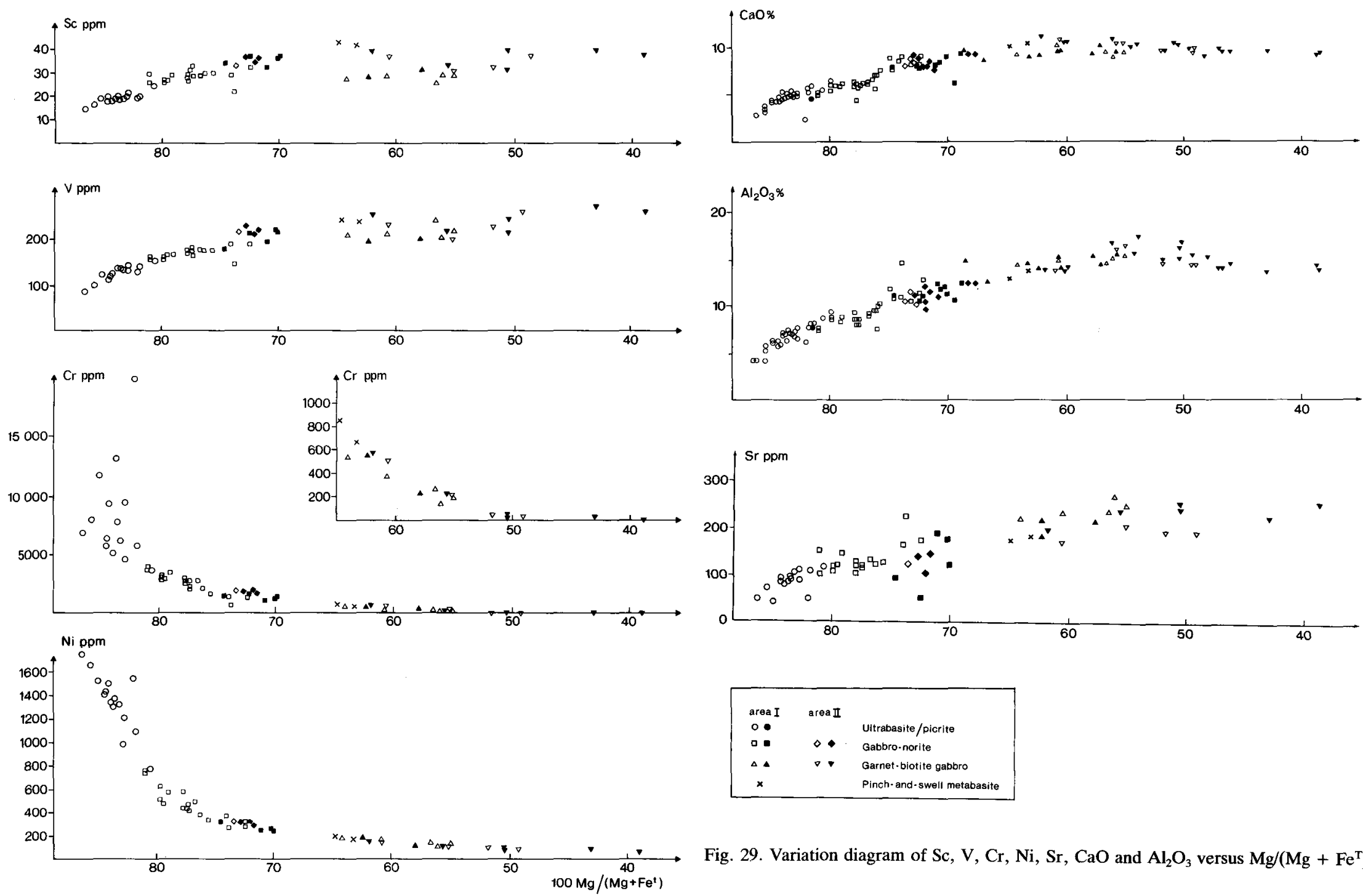

Fig. 29. Variation diagram of $\mathrm{Sc}, \mathrm{V}, \mathrm{Cr}, \mathrm{Ni}, \mathrm{Sr}, \mathrm{CaO}$ and $\mathrm{Al}_{2} \mathrm{O}_{3}$ versus $\mathrm{Mg} /\left(\mathrm{Mg}+\mathrm{Fe}^{\mathrm{T}}\right)$. 
from 52 to $54 \%$, whilst $\mathrm{Mg} /\left(\mathrm{Mg}+\mathrm{Fe}^{\mathrm{T}}\right)$ ranges from about 67 to $80 \%$. A remarkable feature of gabbronorites is the high contents of $\mathrm{MgO}, \mathrm{Ni}$ and $\mathrm{Cr}$ in a relatively silica-rich (often quartz-normative) rock. $\mathrm{MgO}$ typically ranges between 13 and $20 \%$, whilst $\mathrm{Cr}$ attains values between 1400 and $3600 \mathrm{ppm}$ that would elsewhere be expected only in rocks of peridotitic and related compositions. In the absence of $\mathrm{Cr}$-spinel this $\mathrm{Cr}$ is essentially situated in the pyroxenes.

$\mathrm{Cr}$ contents of the garnet-biotite gabbros do not exceed $600 \mathrm{ppm}$. They have $\mathrm{SiO}_{2}$ contents similar to the gabbro-norites, but $\mathrm{Mg} /\left(\mathrm{Mg}+\mathrm{Fe}^{\mathrm{T}}\right)$ may be as low as $35-40 \%$, the lowest values occurring in the central parts of the $200 \mathrm{~m}$ thick metabasite bodies on Ikerasak (samples 267556 and 267557, Table 9), where minimum values of $\mathrm{Ni}$ and $\mathrm{Cr}$ contents are also found.

Due to their dominance of ultrabasic, picritic and gabbro-noritic lithologies the metabasite bodies from area I have distinctly higher bulk contents of $\mathrm{MgO}, \mathrm{Ni}$ and $\mathrm{Cr}$ than their garnet-biotite gabbro dominated counterparts on Ikerasak. $\mathrm{Cr}$ actually decreases by an order of magnitude from the former group to the latter.

In the variation diagrams presented in fig. 29 the complex behaviour of $\mathrm{Al}_{2} \mathrm{O}_{3}$ and $\mathrm{CaO}$ should be noted. The former attains a maximum for samples with $\mathrm{Mg}$ / $\left(\mathrm{Mg}+\mathrm{Fe}^{\mathrm{T}}\right)$ of about $50-55 \%$ whilst the latter reaches maximum values at $\mathrm{Mg} /\left(\mathrm{Mg}+\mathrm{Fe}^{\mathrm{T}}\right)$ of $60-62 \%$. The $\mathrm{Al}_{2} \mathrm{O}_{3}$ maximum coincides with a $\mathrm{Sr}$ maximum and marks the plagioclase-rich sub-zone of garnet-biotite gabbro. The $\mathrm{CaO}$ maximum represents the clinopyroxene-rich marginal sub-zone of metabasite bodies on Ikerasak.

In the olivine-bearing ultrabasites and picrites Sc and $V$ contents are low (fig. 29). They are high in the pyroxene dominated layers, that is gabbro-norites and the fine-grained upper marginal zone of metabasite bodies on Ikerasak, but low in plagioclase-rich garnet-biotite gabbro. Sc reaches a maximum in the amphibolite facies recrystallised pinch-and-swell metabasite body on Qôroq qiterdleq, area I (represented by sample 267498, Table 9). The major element chemistry together with $\mathrm{Cr}$ and $\mathrm{Ni}$ contents of this body are intermediate between gabbro-norite and garnet-biotite gabbro. On the whole its chemistry shows the closest similarity to the clinopyroxene-rich marginal facies of the metabasite bodies on Ikerasak, but it has no exact equivalent among rock types retaining their pre-metamorphic mineralogy.

With a few exceptions $\mathrm{CaO} / \mathrm{Al}_{2} \mathrm{O}_{3}$ ranges between 0.6 and 0.8 throughout the rock suite. An exceptionally low value of 0.41 in the Cr-rich ultrabasic sample 249078 is accounted for by the high content of Cr-spinel (which incorporates $\mathrm{Al}_{2} \mathrm{O}_{3}$ ). Values above unity are never approached.

Contents of $\mathrm{FeO}$ (total) show modest variation between 8.5 and $c .13 \%$ and decreases from ultrabasite through picrite and gabbro-norite to the least evolved

Fig. 30. AFM plot of metabasites. Symbols as in fig. 29. Calc-alkaline (C.A.) and tholeiitic (Thol.) Skaergaard trends (adopted from Nockolds \& Allen, 1953) are shown for comparison.

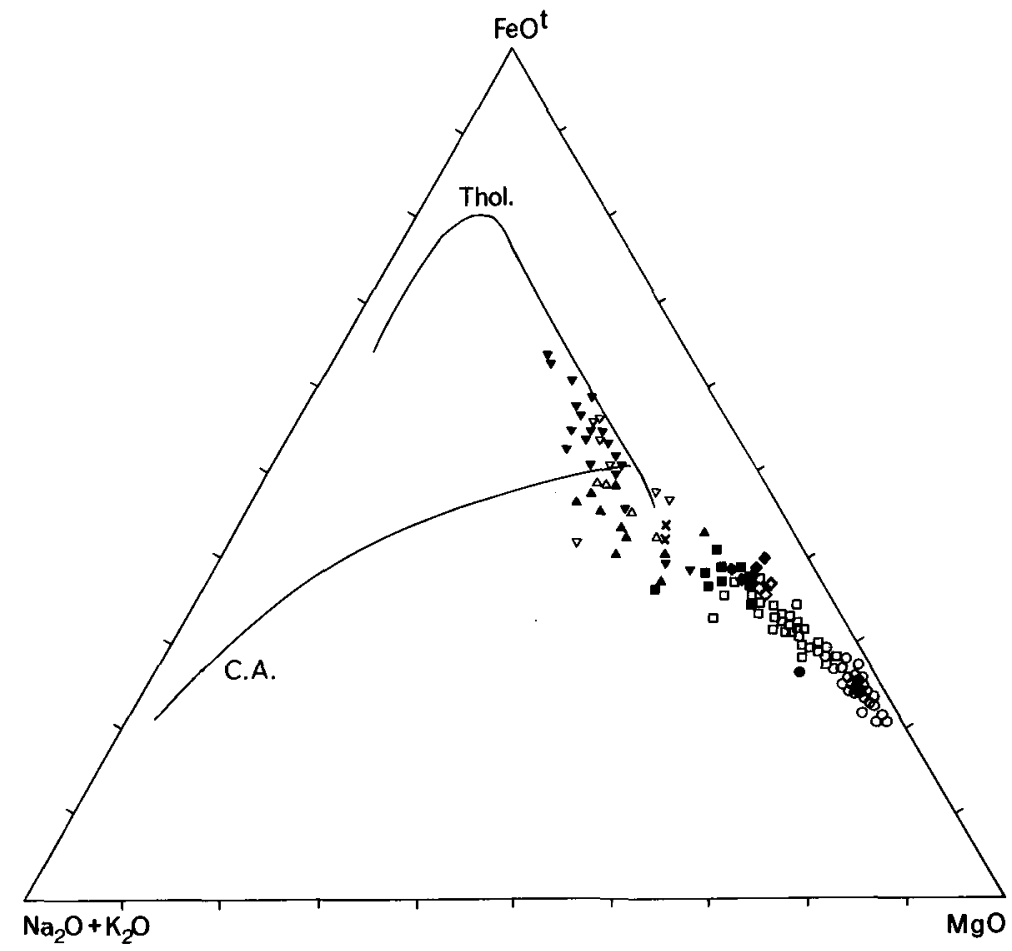


garnet-biotite gabbros. Within the garnet-biotite gabbro compositional range, however, the trend reverses, and the highest Fe contents in the rock suite are found in the most evolved garnet-biotite gabbros on Ikerasak. The oxidation state of Fe has been subject to later alterations. It has most probably increased secondarily in ultrabasic and picritic samples which contain significant amounts of secondary magnetite. The original ratio can only be estimated indirectly. The AFM diagram (fig. 30) indicates a highly reduced tholeiitic Fe-enrichment trend for the rock suite, more similar to the Skaergaard trend than to calc-alkaline trends. In CIPW norm calculations (fig. 31) a hypothetical $\mathrm{Fe}_{2} \mathrm{O}_{3} / \mathrm{FeO}$ ratio of 0.15 was assumed (Brooks, 1976).

Using the $\mathrm{Fe}_{2} \mathrm{O}_{3} / \mathrm{FeO}$ ratio of 0.15 , the correspondence between CIPW norms and modal compositions is satisfactory for gabbro-norites with little or no sign of recrystallisation in amphibolite facies. Due to biotite (calculated as K-feldspar and a Si-poor mineral in the norm), however, these olivine-free rocks may be olivine normative. Whilst ultrabasites and picrites are mostly strongly olivine normative, garnet-biotite gabbros with little or no sign of recrystallisation in amphibolite facies are all quartz normative. Samples from Ikerasak that retain essentially dry mineral assemblages are all quartz normative. Particularly high contents of normative diopside are found in rocks with the highest Sc contents, that is the clinopyroxene-rich marginal samples of metabasite bodies on Ikerasak and the strongly recrystallised pinch-and-swell metabasite body in Qôroq qiterdleq, area I. The slightly corund normative ultrabasic sample in fig. 31 is the Cr-spinel-rich 249078.

Samples near margins of metabasite bodies and, in particular, amphibolite facies recrystallised samples, show irregular alkali contents. In fig. 31 this is most easily seen for gabbro-norites and garnet-biotite gabbros with anomalously high normative olivine. A marginal sample from Ikerasak has $6.69 \%$ normative nepheline. These anomalous alkali patterns are attributed to secondary $\mathrm{Na}, \mathrm{K}$ and $\mathrm{Rb}$ metasomatism. The metasomatism, however, took place in a rather complex way, probably from more than one source. In certain cases it is likely that metabasites were enriched in one element, however depleted in another. Thus the $\mathrm{Na}_{2} \mathrm{O} / \mathrm{K}_{2} \mathrm{O}$ ratio for non-metasomatised samples is between 2 and 4; for the nepheline normative marginal sample in fig. 31 it is 12 , and for samples rich in late biotite the ratio may be as low as $0.2-0.25$. Volatiles seem to be even more disturbed than alkalies.

Contents of incompatible trace elements such as $\mathrm{La}$ and $\mathrm{Zr}$ are rather low in ultrabasites, picrites and gabbro-norites, but increase towards the garnet-biotite gabbroic zone and are particularly high in the central parts of metabasite bodies on Ikerasak.

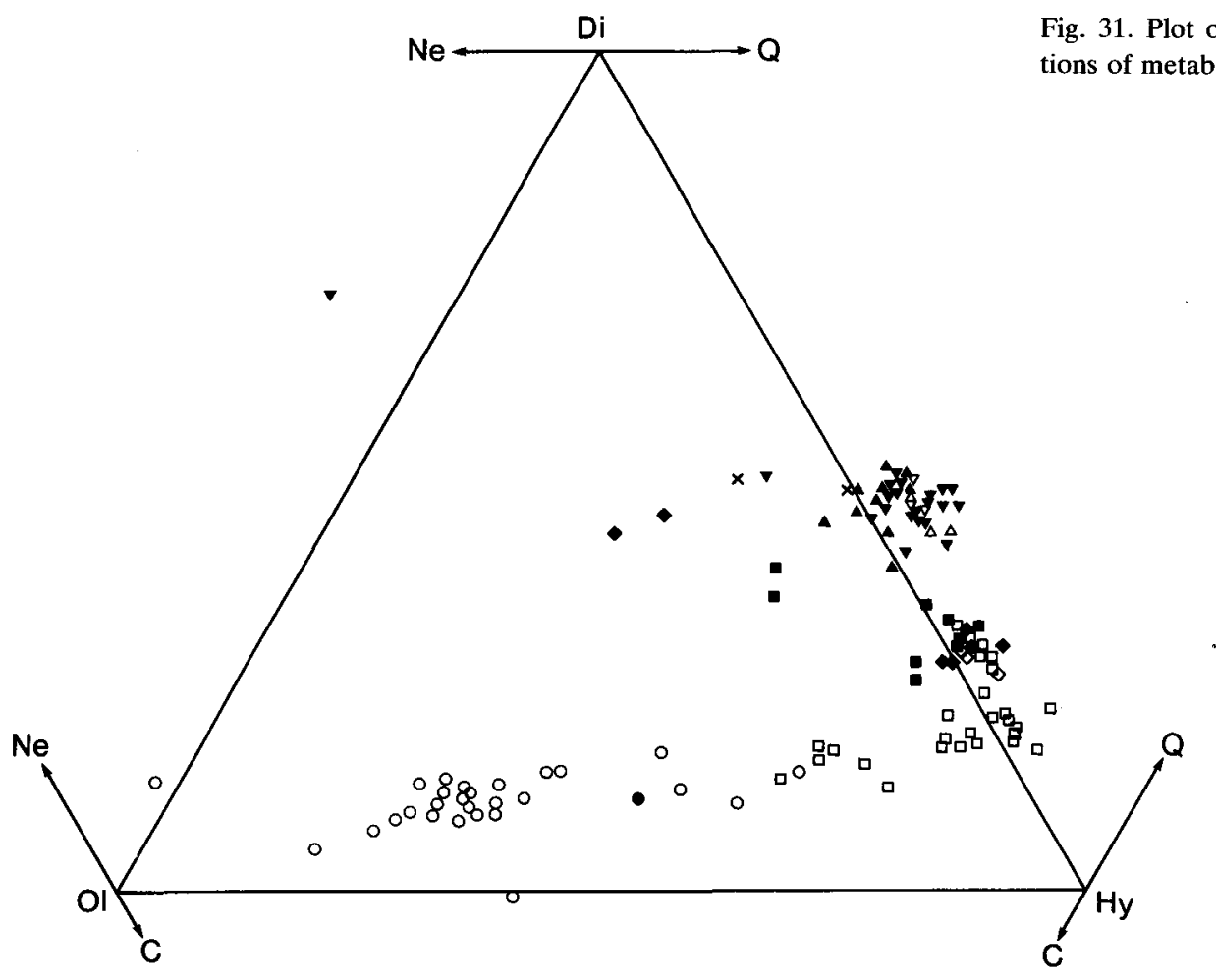




\section{Characteristic trends across metabasite bodies}

Across a typical metabasite body from area I the trend from the original bottom to the top is from high towards low values of $\mathrm{Mg} /\left(\mathrm{Mg}+\mathrm{Fe}^{\mathrm{T}}\right), \mathrm{MgO}, \mathrm{Cr}$ and $\mathrm{Ni}$. Contents of incompatible trace elements increase. The trend may be slightly irregular within individual zones (ultrabasite/picrite, gabbro-norite and garnet-biotite gabbro), but is quite clear when followed from one zone to another. On Ikerasak (area II) this trend reverses in the central part of the metabasite bodies, but $\mathrm{Mg} /(\mathrm{Mg}+$ $\mathrm{Fe}^{\mathrm{T}}$ ), $\mathrm{MgO}, \mathrm{Cr}$ and $\mathrm{Ni}$ never become as high at the upper contact as at the lower. Conversely incompatible trace elements, although decreasing from the central part of the intrusion towards the top, never become as low at the upper contact as at the lower. In both areas a slight reversal of the trend is found at the very bottom of the metabasite body: $\mathrm{Mg} /\left(\mathrm{Mg}+\mathrm{Fe}^{\mathrm{T}}\right)$ decreases from $c$. $85 \%$ to about $82 \%$ at the ultrabasite/gneiss contact of the large metabasite body on southern Tûgdligtalik, and from c. 74 to $70 \%$ at the gabbro-norite/gneiss contact of metabasite bodies on Ikerasak.

Marginal zones of individual metabasite bodies in area I may show considerable lateral variation in chemical composition. $\mathrm{Mg} /\left(\mathrm{Mg}+\mathrm{Fe}^{\mathrm{T}}\right)$ ranges from $c .58$ to $c$. $68 \%$ along the thin amphibolitic border zone of the large metabasite body on southern Tûgdligtalik. In this respect the metabasite bodies on Ikerasak are different. $\mathrm{Mg} /\left(\mathrm{Mg}+\mathrm{Fe}^{\mathrm{T}}\right)$ for the originally uppermost finegrained clinopyroxene-rich marginal facies (or its amphibolitic equivalent) shows a very limited variation between 60 and $62 \%$. In both areas, however, the metabasite bodies show a distinct chemical asymmetry between upper and lower contacts.

\section{Correlations of incompatible trace elements}

The patterns of incompatible trace elements in figs 32,33 and 34 are evidence for the comagmatism between metabasite bodies from the two areas investigated. When plotted against $\mathrm{Zr}$ in log-log diagrams (fig. 32), most of the other incompatible trace elements analysed show satisfactory fits to $45^{\circ}$ lines. Deviations are mainly found within the ultrabasic/picritic range, where contents of these elements (particularly $\mathrm{Nb}$ ) are low and particularly sensitive to analytical uncertainties, secondary element migrations or small deviations from ideal incompatible behaviour.

In fig. 33 metabasites are plotted in Pearce \& Cann's (1973) Ti-Zr-Y discrimination diagram. Although the rock suite is likely to include a large amount of cumulate, all analyses are plotted. Although changing proportions of different cumulus phases and interstitial liq- uid change the absolute contents of the elements, their mutual ratios should not be affected very much. Apart from two ultrabasic samples, all metabasite analyses plot within a relatively narrow range in the field of calc-alkaline rocks. The two anomalous ultrabasites both have unusually high contents of $\mathrm{Cr}$-spinel and low contents of incompatible trace elements. A slight Tideviation from ideal incompatibility in spinel crystallisation is likely to explain these anomalies.

The applicability of the Ti-Zr-Y discrimination diagram as an indicator of tectonic environment is limited for continental intrusive rocks, so the important feature of fig. 33 is that metabasites from the two investigated areas plot together. Samples recrystallised in amphibolite facies actually tend to cluster in a slightly $\mathrm{Zr}$-poorer group than samples with igneous or dry metamorphic texture and mineralogy, indicating slight $\mathrm{Zr}$ mobility during amphibolite facies metamorphism. This agrees with investigations made by Zeck \& Kalsbeek (1981) on part of the Kangâmiut dyke swarm at the southern boundary of the Nagssugtoqidian in West Greenland.

In fig. 34 incompatible trace element contents of selected representative metabasites are normalised to a hypothetical primordial mantle suggested by Wood et al. (1979). The elements are plotted in sequence of increasing incompatibility (Sun \& Nesbitt, 1977; Wood et al., 1979). Interelement ratios of refractory lithophile elements, such as REE, Nb, $\mathrm{Sr}, \mathrm{Zr}$, $\mathrm{Ti}$ and $\mathrm{Y}$ have been given chondritic values in Wood's hypothetical mantle. For volatile elements such as $P, K$ and $R b$ assumed mantle values (46, 120 and $0.35 \mathrm{ppm}$ respectively) are based on the more earth-like element ratios $\mathrm{TiO}_{2} / \mathrm{P}_{2} \mathrm{O}_{5}$ $=10, \mathrm{Rb} / \mathrm{Sr}=0.03$ and $\mathrm{K} / \mathrm{Rb}=350$.

In fig. 34 metabasites from both areas exhibit a gradual decrease in normalised abundances of incompatible elements, from the most incompatible LIL elements to elements that are only moderately incompatible, such as $Y$. In both groups of metabasites $P$ and the high field strength ions of $\mathrm{Nb}$ and $\mathrm{Ti}$ show significant negative anomalies. Sr shows deviational behaviour in sample 267552 from Ikerasak, which showed textural indications of plagioclase enrichment, and thus Sr cannot be regarded as truely incompatible. Since patterns of incompatible trace elements are highly fractionated relative to reasonable estimates of a primordial mantle composition, the similarity between the metabasites from areas I and II is unlikely to be coincidental.

\section{Sm-Nd isotopic characteristics}

REE patterns (estimated from $\mathrm{La}, \mathrm{Ce}, \mathrm{Nd}$ and $\mathrm{Y}$ ) do not show sufficient variation through the rock suite to justify actual dating by the Sm-Nd method. However, 

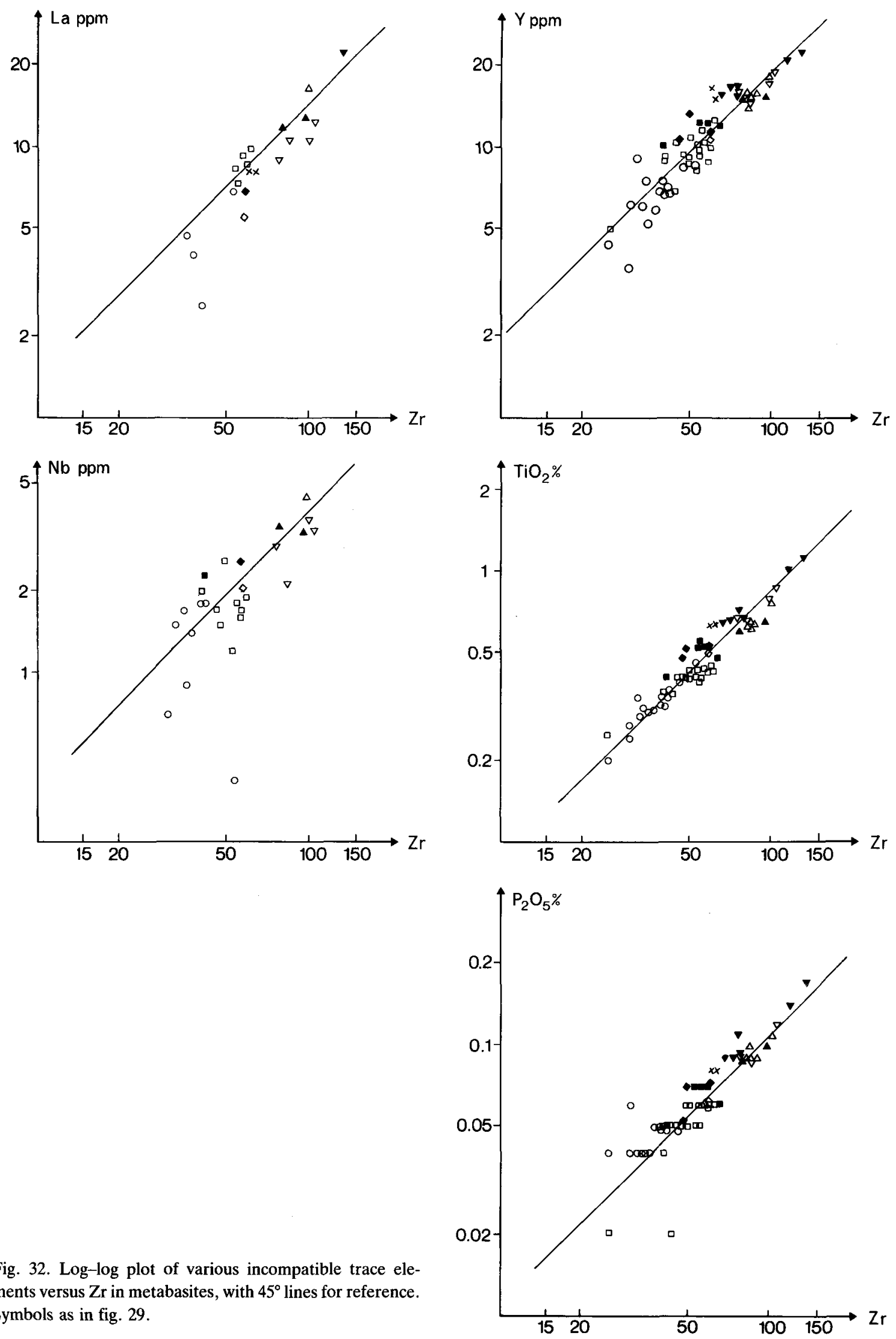

Fig. 32. Log-log plot of various incompatible trace elements versus $\mathrm{Zr}$ in metabasites, with $45^{\circ}$ lines for reference. Symbols as in fig. 29 . 


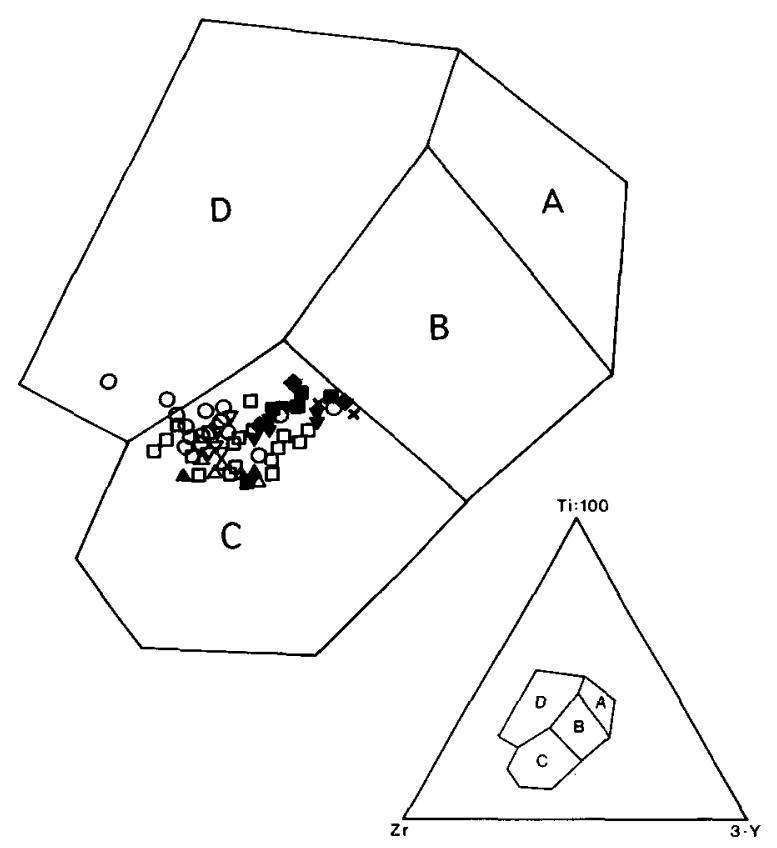

Fig. 33. Metabasite analyses plotted in the $\mathrm{Ti} / 100-\mathrm{Zr}-3 \mathrm{xY}$ diagram of Pearce \& Cann, 1973. Symbols as in fig. 29. A: Field of low-K tholeiites. B: Field of low-K tholeiites, ocean floor basalts and calc-alkaline basalts. C: Field of calc-alkaline basalts and the majority of boninites (as apparent from data by Jenner, 1981 and Hickey \& Frey, 1982). D: Field of withinplate basalts.

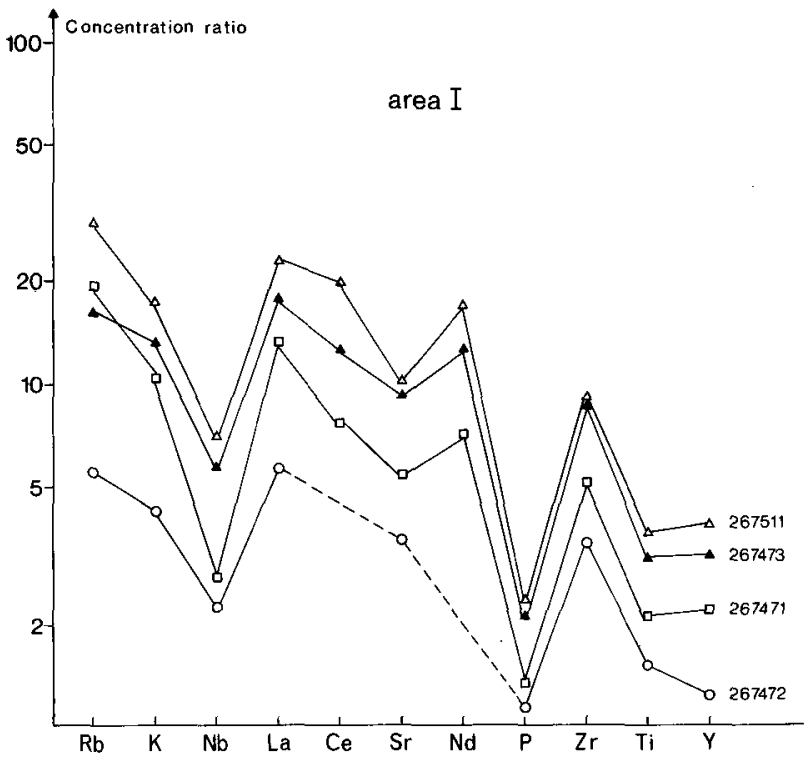

assuming a plausible age for the intrusion event, information about the source area can be obtained from initial $\varepsilon \mathrm{Nd}$ values. From a section across the central metabasite body on Ikerasak, where the dry mineral assemblage is particularly well preserved, a garnet-biotite gabbroic sample (267556) was analysed for Sm-Nd isotopic chemistry. The following values were obtained:

${ }^{147} \mathrm{Sm} /{ }^{144} \mathrm{Nd}=0.1371 \pm 3$ and ${ }^{143} \mathrm{Nd} /{ }^{144} \mathrm{Nd}=0.511606$ \pm 14 .

Relative to a chondritic uniform reservoir (CHUR, Jacobsen \& Wasserburg, 1984) this corresponds to an $\varepsilon \mathrm{Nd}$ of -6.39 at $1800 \mathrm{Ma}$ and -0.19 at $2600 \mathrm{Ma}$. Thus the initial $\varepsilon \mathrm{Nd}$ attains negative values in the whole range of plausible ages between the $\mathrm{Rb}-\mathrm{Sr}$ age of the Archaean basement and the age of the Rinkian overprint. This non-radiogenic initial $\mathrm{Nd}$ composition indicates either crustal contamination or an unusual mantle source that was enriched in LREE relative to HREE at some time before the intrusion event. The older the assumed age of intrusion, the smaller the amount of crustal contamination, or alternatively the shorter the time span between the mantle enrichment and the intrusion event.

\section{Discussion}

\section{Factors controlling igneous evolution}

It appears from the foregoing that metabasite bodies in the Umanak district constitute a comagmatic series of

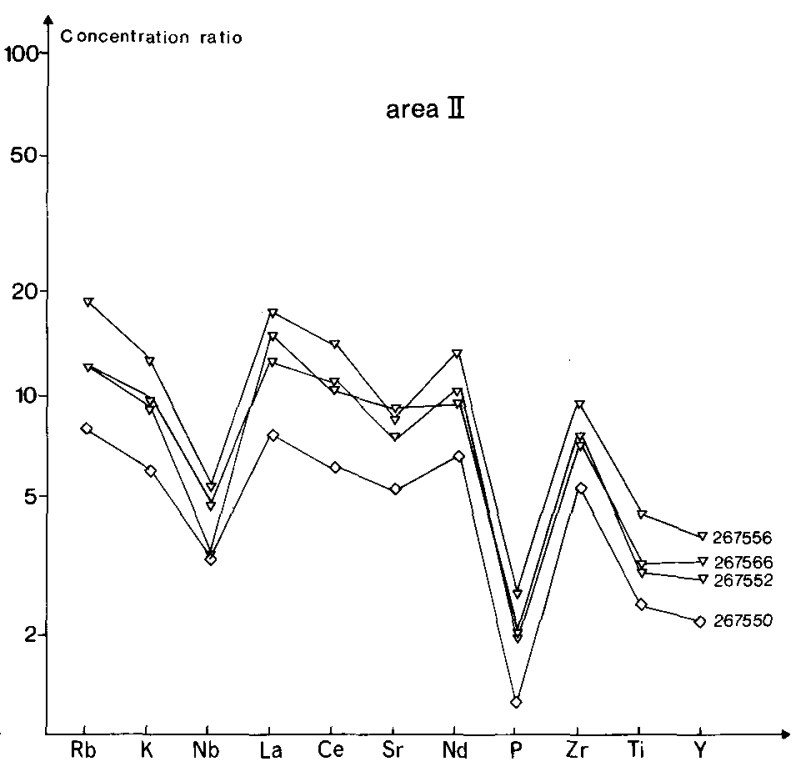

Fig. 34. Incompatible trace element patterns of metabasites normalised to hypothetical primordial mantle values (given in ppm below) of Wood et al. (1979). Symbols as in fig. 29.

\begin{tabular}{|c|c|c|c|c|c|c|c|c|c|c|}
\hline $\mathrm{Rb}$ & K & $\mathrm{Nb}$ & $\mathrm{La}$ & $\mathrm{Ce}$ & $\mathrm{Sr}$ & $\mathrm{Nd}$ & $\mathbf{P}$ & $\mathrm{Zr}$ & $\mathrm{Ti}$ & $Y$ \\
\hline 0.86 & 252 & 0.62 & 0.71 & 1.90 & 23 & 1.29 & 90.4 & 11 & 1527 & 4.87 \\
\hline
\end{tabular}


layered intrusions. The rocks range from strongly olivine normative ultrabasites and picrites through moderately olivine normative and quartz normative gabbronorites to quartz normative garnet-biotite gabbros. Metabasite bodies from the two areas investigated in detail show compositional overlap in the quartz normative gabbro-norite range and part of the garnet-biotite gabbro range. Since $\mathrm{MgO}, \mathrm{Cr}$ and $\mathrm{Ni}$ (together with values of $\mathrm{Mg} /\left(\mathrm{Mg}+\mathrm{Fe}^{\mathrm{T}}\right)$ decrease and incompatible trace elements increase from typical metabasite bodies in area I to their counterparts in area II (Ikerasak), the latter represent the more evolved stages of igneous evolution.

Although a quenched dyke with boninitic affinities that was recently described from the eastern Sukkertoppen region, southern West Greenland (Hall \& Hughes, 1986) shows some chemical resemblances to the gabbronoritic zones in the metabasite bodies dealt with here, most of the rock types described have chemical and mineralogical compositions that are hardly compatible with a direct interpretation as former melts. This is particularly true for the more mafic rocks in metabasite bodies from area $I$. They should rather be interpreted as cumulates or as crystal enriched liquids. Since the rocks are all partially re-equilibrated and recrystallised, a detailed interpretation in terms of adcumulates, orthocumulates, melt fraction etc. cannot be given, but reasonable suggestions as to major factors controlling the igneous evolution can be made by a combination of petrographic and chemical evidence.

Fractional crystallisation of olivine, Cr-spinel, orthopyroxene, clinopyroxene and plagioclase was probably the most important controlling factor. Whilst ultrabasic/ picritic zones developed during olivine and $\mathrm{Cr}$-spinel settling, gabbro-norites are zones of orthopyroxene concentration. The plagioclase-rich parts of the garnetbiotite gabbro zone in the metabasite bodies on Ikerasak are the best candidates for plagioclase accumulation zones. The maximum anorthite content attained by plagioclase in these zones is only $68 \%$. This indicates that the cumulus plagioclase coexisted with mafic minerals that were significantly more evolved than the earliest cumulus orthopyroxene in gabbro-norites for which En contents as high as $79 \%$ have been measured (compare e.g. coexisting plagioclase and mafic minerals in Bushveld and Skaergaard cumulates (Wager \& Brown, 1968)). Thus plagioclase is supposed to have started crystallising after orthopyroxene.

The chemical asymmetry displayed by upper and lower marginal zones must be due to either crystal accumulation near the margin or to different evolutionary stages of the liquid, or both. The originally upper margin of the metabasite bodies on Ikerasak seems to have been an important concentration zone for clinopyroxene. The chemically evolved central zone of metabasite bodies on Ikerasak shows no clear textural or chemical indications of crystal accumulation and might be the frozen equivalent of an evolved melt.

The maintenance of a nearly constant $\mathrm{Ti} / \mathrm{Zr}$ ratio shows that Ti acted as an incompatible element, so although rutile and ilmenite are important accessory minerals, fractional crystallisation of Fe-Ti oxides probably did not take place. Similar conclusions can be drawn from the highly reduced trend in the AFM diagram (fig. 30) and the high $\mathrm{V}$ contents in the most evolved rocks. The rutile-ilmenite aggregates have probably recrystallised from oxides crystallising from an interstitial liquid.

For the sake of completeness it is stressed that the incompatibility of $\mathrm{Y}$ (apparent from figs 32-34) is a strong argument against fractionation of igneous garnet.

Considering the restricted thickness of individual intrusions, their differentiation is remarkable. In particular the confinement of olivine to the ultrabasic/picritic lowermost layer in the small metabasite bodies in area I should be noted. The occurrence of primitive mafic minerals together with anorthite-poor interstitial plagioclase in picrite and gabbro-norite zones and conversely the occurrence of a primitive anorthite-rich plagioclase together with evolved interstitial pyroxenes in the plagioclase enriched garnet-biotite gabbro testify to complicated differentiation phenomena. It is difficult to imagine that this all took place after emplacement of the relatively small intrusion bodies. Although metabasite bodies on Ikerasak on the whole represent a more evolved stage in the igneous evolution, the occurrence of the most primitive plagioclase of the whole rock suite within these bodies shows that they are not simple derivates of their counterparts in area I. Some differentiation probably took place in a common magma reservoir before injection.

\section{Speculations on the magma source}

Metasomatised mantle sources, that is depleted subcontinental mantle that has been secondarily enriched during addition of a fluid phase, have been a popular concept in recent work on late Archaean and early Proterozoic basic intrusions. In their work on the Scottish Scourie dyke suite Weaver \& Tarney (1981) presented patterns of incompatible trace elements similar to those presented in fig. 34 as evidence for such a mantle source. Particular attention was given to negative $\mathrm{Nb}$ and $\mathrm{Ti}$ anomalies which are also seen in fig. 34 . It was speculated that the fluid originated from a subducted oceanic slab and that $\mathrm{Ti}$ and $\mathrm{Nb}$ were retained in 
Fe-Ti oxides in this slab. Hamilton (1977) suggested a mantle with secondarily elevated $\mathrm{Rb} / \mathrm{Sr}$ of 0.25 and LREE enrichment as the source for the Bushveld intrusion and the Great 'Dyke' of Zimbabwe. Sheraton \& Black (1981) suggested a similar mantle source for 2350 Ma old basic intrusions on East Antarctica.

The trace element patterns and Sm-Nd isotopic chemistry of the metabasites from the Umanak district are all compatible with a metasomatised mantle source; but before anything is concluded about the mantle source, the possibility of crustal contamination should be considered. Since incompatible trace elements (with the exception of alkalies) maintain constant interelement ratios in samples from all parts of the intrusions, contamination with country rock during and after emplacement can be ruled out. However, crustal contamination could have occurred in a crustal magma chamber before the magma divided into individual bodies. It could even have occurred during melting if this took place at the mantle/crust boundary. Considering that differentiation in a common magma reservoir in any case seems to be required to explain the petrological diversity of the metabasite bodies, contamination in a crustal magma chamber is tentatively accepted as the simplest explanation for the trace element patterns and isotopic chemistry of the metabasite bodies.

Certain similarities with the lower, transitional and critical zones in the Bushveld complex (Cameron, 1971; Liebenberg, 1960) are seen in the early high-Mg end of the metabasite suite, before plagioclase fractionation became important. The high initial $\mathrm{Cr}$ contents and the dominance of accumulating $\mathrm{Ca}$-poor pyroxene are important characteristics. These features are also shared by the modern boninite suite (Hickey \& Frey, 1982), but contrary to boninites the metabasite suite follows a very reduced evolutionary trend.

\section{Timing of metamorphism}

It is debatable whether the dry metamorphic mineral assemblages belong to a geological event separate from the main amphibolite facies metamorphism. Since cloudy plagioclase, platy pyroxene oikocrysts and equivalent parageneses in more felsic parts of the rock suite break down during growth of amphibolite facies mineral assemblages, it could be argued that these dry minerals are autometamorphic. The dry and the waterrich metamorphic mineral assemblages could, however, also represent different stages of recrystallisation during one and the same metamorphic event. Since the igneous bodies were probably dry, the development of metamorphic minerals would come to a halt in those metabasite bodies where water was not provided from outside. Considering the scarcity of granulite facies in the main gneiss in Umanak Fjord, the dry parageneses are unlikely to be reminiscent of a regional granulite facies metamorphism.

Cloudy plagioclase has been reported from late Archaean or early Proterozoic basic dykes in the Sukkertoppen area, southern West Greenland (Berthelsen \& Bridgwater, 1960). Unfortunately no details are given about the origin of this clouding. If it is the same type as the spinel clouding in plagioclase from picritic zones in the metabasite bodies from the Umanak district, their occurrence in dykes well away from the Proterozoic mobile belts could be seen as indicating autometamorphic origin.

\section{Regional comparisons}

Basic magmatism was widespread in the North Atlantic region in late Archaean and early Proterozoic times. Escher et al. (1976) introduced the concept of a major North Atlantic Dyke Swarm, including the Scottish Scourie dykes, the MD dykes and Kangâmiut dykes in Greenland and dykes of similar age in Labrador. Although on closer inspection this dyke swarm has shown to be a heterogeneous assemblage of intrusions ranging in age from c. 2390 to 1950 Ma (Chapman, 1979; Kalsbeek et al., 1978; Kalsbeek \& Taylor, 1985), it may still be worth seeing the basic intrusions in the Umanak district in a North Atlantic context.
In terms of elevated $\mathrm{MgO}, \mathrm{Cr}$ and $\mathrm{Ni}$ contents and the dominance of orthopyroxene the metabasite bodies described here resemble the picritic-noritic/olivine gabbroic suite of the Scourie dykes (Tarney, 1973). They share these similarities with the BN dykes in the Sukkertoppen region of southern West Greenland (previously classified as MD1 dykes, but now regarded as a separate unit (Berthelsen \& Bridgwater, 1960; Hall \& Hughes, 1986)), but contrary to the BN dykes the metabasite bodies in the Umanak district follow a strongly reduced trend.

Different stress patterns in the continental crust in the 
Umanak district as compared to other parts of the craton may explain why the late Archaean or early Prote- rozoic basic intrusions here were emplaced as sub-horizontal sheets rather than dykes.

\section{Concluding remarks}

Metabasite bodies in the Umanak district constitute a series of tholeiitic layered intrusions. The superficially dissimilar garnet-biotite gabbro dominated bodies that predominate in certain parts of the district and the more mafic types that predominate elsewhere have been shown to be consanguinous. They represent different evolutionary stages of the same igneous event. Some magma differentiation has taken place in a common reservoir before the division into individual sheet-like bodies. A reduced evolutionary trend with strong $\mathrm{Fe}-$ enrichment is followed. Fractional crystallisation of olivine, Cr-spinel, orthopyroxene, clinopyroxene and plagioclase was the major controlling factor. In terms of volume, orthopyroxene dominated cumulate rocks are dominant.

$\mathrm{Cr}$ contents of several thousand parts per million are a striking geochemical feature in the more mafic part of the rock suite. Away from the ultrabasic/picritic zones this $\mathrm{Cr}$ is essentially situated in pyroxenes. Trace element patterns and $\mathrm{Sm}-\mathrm{Nd}$ isotope chemistry are compatible with both crustal contamination during differentiation in a crustal magma chamber and with an enriched mantle source. The first of these alternatives is considered the most likely. Crustal contamination during or after emplacement did not take place.

The metabasite bodies are isoclinally folded and so predate the main Rinkian orogenesis. The blurred upper contacts of the more mafic metabasite bodies are seen as indications of intrusion into a hot country rock.

The igneous mineral assemblages are overprinted by metamorphic parageneses. The earliest metamorphism was dry, causing growth of spinel in plagioclase in the picritic part of the rock suite and garnet growth in the least mafic part. Amphibolite facies parageneses have in turn grown at the expense of the dry metamorphic mineral assemblage. The two stages of overgrowth could be regarded either as reflecting successively stronger Rinkian overprinting, or the dry mineral assemblages could be autometamorphic, in which case the two stages of overgrowth could be widely separated in time. Occasional breakdown of these igneous and metamorphic parageneses took place in turn during a weak retrogressive greenschist facies metamorphism.

\section{Acknowledgements}

This work was carried out as part of a thesis project including geological mapping at 1:20 000 scale under the auspices of the Geological Survey of Greenland. T. C. R. Pulvertaft, Geological Central Institute, University of Copenhagen, who acted as supervisor and improved the English of the manuscript, is gratefully acknowledged, and A. K. Pedersen, A. A. Garde and F. Kalsbeek are acknowledged for constructive criticism.

I also wish to thank K. Kromphardt and O. B. Sørensen for assistance during field work in 1979 and 1980.

The microprobe facilities were funded by the Danish Natural Science Research Council. J. C. Bailey, J. Fløng, A. K. Pedersen and J. Rønsbo, who supervised the XRF and microprobe work, are gratefully acknowledged. P. Vidal and others at l'Université de Clermont II, CNRS LA 10, Clermont-Ferrand are acknowledged for assistance with the isotopic work.

J. Grocott is acknowledged for interesting and inspiring discussions during our stay in Søndre Strømfjord in 1980 .

\section{Appendix: analytical procedures}

Major element XRF whole rock analyses were provided by the Geological Survey of Greenland (see Sørensen, 1975 for details), whilst trace element XRF analyses were carried out on the Philips PW 1410/20 at the Institute of Petrology, Geological Institute, University of Copenhagen.

Mineral chemistry is based on crystal spectrometer analyses on the JEOL 733 Superprobe at the Institute of 
Mineralogy, Geological Institute, University of Copenhagen, using the JEOL PACX-M program for instrumental automatisation and ZAF correction. The analyses were performed by an acceleration voltage of $15 \mathrm{kV}$, a beam current of $20 \mathrm{nA}$ and focused beam. Major standards were periclase, albite, corund, wollastonite, and hematite. Olivine $(\mathrm{Mg}, \mathrm{Fe}, \mathrm{Si})$, orthopyroxene ( $\mathrm{Mg}, \mathrm{Fe}, \mathrm{Si}, \mathrm{Al}$ ), clinopyroxene ( $\mathrm{Mg}, \mathrm{Fe}, \mathrm{Si}, \mathrm{Ca}, \mathrm{Na}$ ), garnet $(\mathrm{Mg}, \mathrm{Fe}, \mathrm{Si}, \mathrm{Al}, \mathrm{Ca}, \mathrm{Mn})$ and $\mathrm{Cr}$-spinel $(\mathrm{Cr}, \mathrm{Mg}$, $\mathrm{Fe}, \mathrm{Al}, \mathrm{Ti}$ ) were in turn subjected to minor adjustments by use of secondary mineral standards.

Sample digestion for Sm-Nd analyses was carried out in a closed teflon beaker with a mixture of $\mathrm{HF}-\mathrm{HNO}_{3}-$
$\mathrm{HCl}$ concentrated acids. Separation of $\mathrm{Sm}$ and $\mathrm{Nd}$ was achieved on two ion-exchange columns, with Bio-Rad AG 50X8 resin for the first one and Bio-Rad AG 1X8 for the second. Isotopic analyses were made on the VG $54 \mathrm{E}$ mass spectrometer at l'Université de Clermont II in France, with double collector for Nd measurements and single collector for $\mathrm{Sm}$. Sm was run on a single tantalum filament (loaded with $\mathrm{H}_{3} \mathrm{PO}_{4}$ ), whereas $\mathrm{Nd}$ was run on a triple filament (a central rhenium and two lateral tantalum filaments). ${ }^{143} \mathrm{Nd} /{ }^{144} \mathrm{Nd}$ was normalised to ${ }^{146} \mathrm{Nd} /{ }^{144} \mathrm{Nd}=0.7219$, with an internal check of consistency by simultaneous measurement of ${ }^{145} \mathrm{Nd} /{ }^{144} \mathrm{Nd}$.

\section{References}

Andersen, M. C. \& Pulvertaft, T. C. R. 1985: Rb-Sr whole rock 'ages' from reworked basement gneisses in Umanak area, central West Greenland. Bull. geol. Soc. Denmark 34, 205-212.

Berthelsen, A. \& Bridgwater, D. 1960: On the field occurrence and petrography of some basic dykes of supposed pre-Cambrian age from the southern Sukkertoppen district western Greenland. Bull. Grønlands geol. Unders. 24 (also Meddr Grønland 123,2), 43 pp.

Brooks, C. K. 1976: The $\mathrm{Fe}_{2} \mathrm{O}_{3} / \mathrm{FeO}$ ratio of basalt analyses: an appeal for a standardized procedure. Meddr dansk geol. Foren. 25, 117-120.

Cameron, E. N. 1971: Problems of the eastern Bushveld Complex. Fortschr. Miner. 48, 86-108.

Chapman, H. J. 1979: $2390 \mathrm{Myr}$ Rb-Sr whole-rock age for the Scourie dykes of north-west Scotland. Nature, Lond. 277, 642-643.

Deer, W. A., Howie, R. A. \& Zussman, J. 1978: Rock-forming minerals 2A: Single-chain silicates. (2nd ed.), $668 \mathrm{pp}$. New York: John Wiley \& Sons.

Escher, A., Jack, S. \& Watterson, J. 1976: Tectonics of the North Atlantic dyke swarm. Phil. Trans. R. Soc. Lond. A 280, 529-539.

Escher, A. \& Pulvertaft, T. C. R. 1976: Rinkian mobile belt of West Greenland. In Escher, A. \& Watt, W. S. (edit.) Geology of Greenland, 104-119. Copenhagen: Geol. Surv. Greenland.

Garde, A. A. 1978: The lower Proterozoic Marmorilik Formation east of Mârmorilik, West Greenland. Meddr Grønland $200(3), 71 \mathrm{pp}$

Grocott, J. 1981: Structural evolution of the Ikerasak area Umanak district, central West Greenland. Rapp. Grønlands geol. Unders. 105, 33-35.

Grocott, J. 1982: Structural evolution of Ikerasak, Talerua and part of Drygalskis Halvø, Umanak district, central West Greenland. Unpubl. intern. GGU rep., 61 pp.
Hall, R. P. \& Hughes, D. J. 1986: A boninitic dyke in the eastern Sukkertoppen region: geochemistry of the boniniticnoritic dyke swarm of southern West Greenland. Rapp. Grønlands geol. Unders. 130, 44-52.

Hamilton, J. 1977: Isotope and trace element studies of the Great Dyke and Bushveld mafic phase and their relation to early Proterozoic magma genesis in southern Africa. J. Petrol. 18, 24-50.

Henderson, G. 1969: The use of structural contour maps in the study of gneiss-metasediment relations in the Umanak area, West Greenland. Geol. Ass. Can. Spec. Paper 5, 129-142.

Hickey, R. L. \& Frey, F. A. 1982: Geochemical characteristics of boninite series volcanics: implications for their source. Geochim. cosmochim. Acta 46, 2099-2115.

Huebner, J. S. 1980: Pyroxene phase equilibria at low pressure. In Prewitt, C. (edit.) Reviews in mineralogy 7, Pyroxenes, 213-278. Washington: Min. Soc. Am.

Jacobsen, S. B. \& Wasserburg, G. J. 1984: Sm-Nd isotopic evolution of chondrites and achondrites, II. Earth planet. Sci. Lett. 67, 137-150.

Jenner, G. A. 1981: Geochemistry of high-Mg andesites from Cape Vogel, Papua New Guinea. Chem. Geol. 33, 307-332.

Kalsbeek, F. 1981: The northward extent of the Archaean basement of Greenland - a review of Rb-Sr whole-rock ages. Precambrian Res. 14, 203-219.

Kalsbeek, F. \& Taylor, P. N. 1985: Age and origin of early Proterozoic dolerite dykes in South-West Greenland. Contrib. Miner. Petrol. 89, 307-316.

Kalsbeek, F. Bridgwater. D. \& Zeck, H. P. 1978: A $1950 \pm 60$ $\mathrm{Ma} \mathrm{Rb-Sr}$ whole-rock isochron age from the Kangâmiut dykes and the timing of the Nagssugtoqidian (Hudsonian) orogeny in West Greenland. Can. J. Earth Sci. 15, 11221128.

Leake, B. E. 1978: Nomenclature of amphiboles. Can. Miner. 16, 501-520.

Liebenberg, C. J. 1960: The trace elements of rocks of the 
Bushveld Igneous Complex. Publ. Univ. Pretoria, New Ser. 12, 1-69.

McLelland, J. M. \& Whitney, P. R. 1980: Compositional controls on spinel clouding and garnet formation in plagioclase of olivine meta-gabbros, Adirondack Mountains, New York. Contr. Miner. Petrol. 73, 243-251.

Nockolds, S. R. \& Allen, R. 1953: The geochemistry of some igneous rock series. Geochim. cosmochim. Acta 4, 105-142.

Pearce, J. A. \& Cann, J. R. 1973: Tectonic setting of basic volcanic rocks determined using $\mathrm{Ti}, \mathrm{Y}$ and $\mathrm{Zr}$. Earth planet. Sci. Lett. 19, 290-300.

Pulvertaft, T. C. R. 1973: Recumbent folding and flat-lying structure in the Precambrian of northern West Greenland. Phil. Trans. $R$. Soc. Lond. A 273, 535-545.

Pulvertaft, T. C. R. 1979: Mapping in the Umanak district, central West Greenland. Rapp. Gronlands geol. Unders. 95, 27-30.

Pulvertaft, T. C. R. 1986: The development of thin thrust sheets and basement-cover sandwiches in the southern part of the Rinkian belt, Umanak district, West Greenland. Rapp. Grønlands geol. Unders. 128, 75-87.

Schiøtte, L. 1981: Metabasite bodies as chronological and structural markers in the gneisses east of Sãtut, Umanak district, central West Greenland. Rapp. Grønlands geol. Unders. 105, 36-37.

Schreiber, H. D. 1976: The experimental determination of redox states, properties and distribution of chromium in synthetic silicate phases and application to basalt petrogenesis. Ph.D. thesis, Univ. Wisconsin. 222 pp.

Schreiber, H. D. \& Haskin, L. A. 1976: Chromium in basalt: experimental determination of redox states and partitioning among synthetic silicate phases. Proc. 7th Lunar Sci. Conf. 1221-1259.

Sheraton, J. W. \& Black, L. P. 1981: Geochemistry and geo- chronology of Proterozoic tholeiitic dykes of East Antarctica: evidence for mantle metasomatism. Contr. Miner. Petrol. 78, 305-317.

Sørensen, I. 1975: X-ray fluorescence spectroscopy at GGU. Rapp. Grønlands geol. Unders. 75, 16-18.

Stevens, R. E. 1944: Composition of some chromites of the western hemisphere. Am. Miner. 29, 1-34.

Sun, S-S. \& Nesbitt, R. W. 1977: Chemical heterogeneity of the Archaean mantle, composition of the Earth and mantle evolution. Earth planet. Sci. Lett. 35, 429-448.

Tarney, J. 1973: The Scourie dyke suite and the nature of the Inverian event in Assynt. In Park, R. G. \& Tarney, J. (edit.) The early Precambrian of Scotland and related rocks of Greenland, 105-118. Newcastle-under-Lyme: Dept. Geol. Univ. Keele.

Wager, L. R. \& Brown, G. M. 1968: Layered igneous rocks. 588 pp. London: Oliver and Boyd.

Weaver, B. L. \& Tarney, J. 1981: The Scourie dyke suite: petrogenesis and geochemical nature of the Proterozoic subcontinental mantle. Contr. Miner. Petrol. 78, 175-188.

Whitney, P. R. 1972: Spinel inclusions in plagioclase of metagabbros from the Adirondack Highlands. Am. Miner. 57, 175-188.

Whitney, P. R. \& McLelland, J. M. 1973: Origin of coronas in metagabbros of the Adirondack Mts., N.Y. Contr. Miner. Petrol. 39, 81-98.

Wood, D. A., Jaron, J-L., Treuil, M., Norry, M. \& Tarney, J. 1979: Elemental and $\mathrm{Sr}$ isotope variations in basic lavas from Iceland and the surrounding ocean floor. The nature of mantle source inhomogeneities. Contr. Miner. Petrol. 70, 319-340.

Zeck, H. P. \& Kalsbeek, F. 1981: Geochemistry of amphibolite facies metamorphism of a suite of basic dykes, Precambrian basement, Greenland. Chem. Erde 40, 1-22. 
